Figura 22 O trem na Índia.

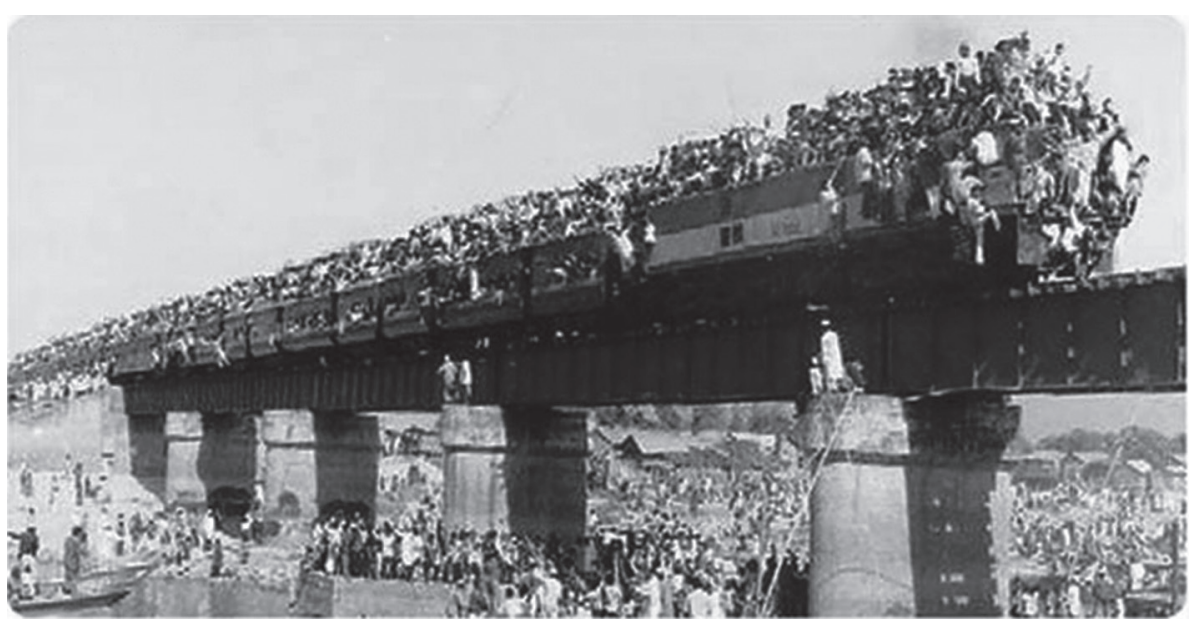

Fonte: BangedUP?com. 



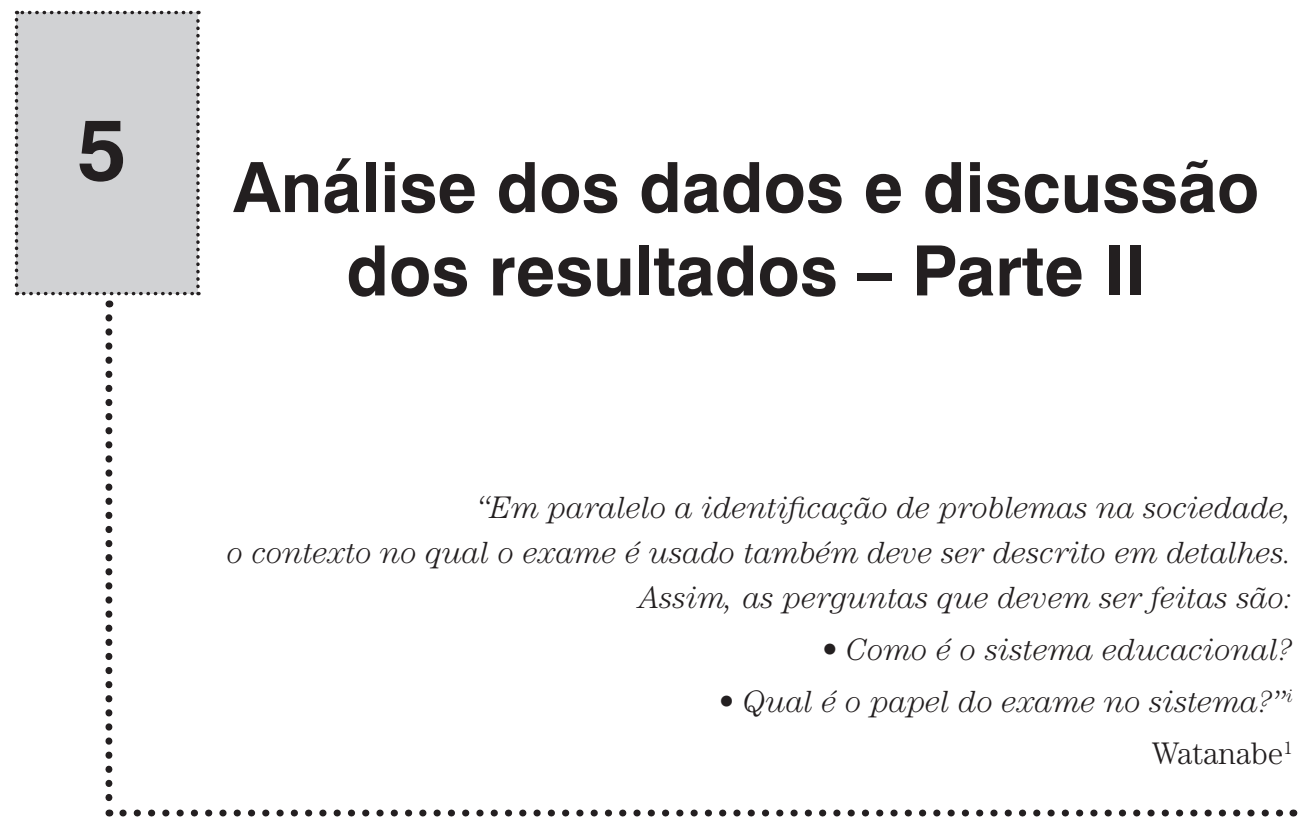

No capítulo anterior, analisamos documentos oficiais tais como PCNEM e PCN+. Também avaliamos os planejamentos de aulas elaborados pelos professores e escolas para averiguarmos se havia ou não convergências entre concepções do exame de língua inglesa do vestibular da UFPR, e quais eram os objetivos de tais documentos. O manual do candidato assim como as provas de inglês do vestibular da UFPR foram analisados para verificarmos a concepção de leitura que está subjacente e se o discurso do documento converge com as provas. Além disso, abordamos as concepções dos elaboradores da prova de língua inglesa do vestibular da UFPR sobre o exame e sobre o ensino da língua no ensino médio. Por fim, vimos o que a coordenadora para o ensino da língua inglesa da Secretaria Estadual da Educação pensa sobre o ensino de língua inglesa nas escolas e suas impressões sobre a prova de língua inglesa do vestibular da UFPR.

Neste capítulo, analisaremos os três cenários deste estudo. Na seção 5.1 e 5. 2, estudaremos as escolas públicas. Na 5.3 e 5. 4, investigaremos as escolas particulares. Na 5. 5, 5. 6 e 5. 7, olharemos os cursos pré-vestibulares. As três

1 WATANABE, Y. Methodoloy in Washback Studies. In.: Washback in Language Testing - Research Contexts and Methods. Lawrence Erlbaum Associates, Inc. New Jersey, 2004, p. 25 
seções serão subdivididas em cinco sub-seções. Na primeira, procuraremos analisar quais as percepções dos diretores e coordenadores sobre o ensino de língua inglesa e a prova de inglês do vestibular da UFPR. Na segunda, analisaremos o que os professores das escolas investigadas pensam sobre seu ensino e a sobre a prova de língua inglesa do vestibular. Na terceira, analisaremos os dados de observação de aulas desses professores. Na quarta, é a vez de analisarmos as percepções dos alunos das escolas investigadas em relação ao ensino da língua inglesa no ensino médio e curso pré-vestibular e a prova de inglês do vestibular da UFPR. Na quinta e última sub-seção, veremos como os elaboradores de materiais estabelecem os objetivos para seus materiais didáticos.

\subsection{A ESCOLA PÚBLICA RURAL}

A Escola EFA recebe seus alunos das regiões rurais do município de Quitandinha, no Estado do Paraná. São alunos das classes C, D e E, com pouco conhecimento de língua estrangeira, como já dissemos.

Como muitos alunos são filhos de agricultores, o inglês para essa comunidade não tem a mesma importância que para os alunos de classes A, B e C dos centros urbanos. A escola oferece aulas de língua inglesa somente no segundo e terceiro anos do ensino médio. O livro didático usado é o "Inglês - Série Novo Ensino Médio" de Amadeu Marques, e que foi escolhido pelos professores por causa do baixo preço. Para que todos os alunos pudessem utilizar o livro, a pedido da escola, cada aluno de todas as séries do ensino médio deu $\mathrm{R} \$ 2,00$. Foi comprado, então, um conjunto de 40 livros para ser usado coletivamente por todas as salas. Após essa compra, os professores fizeram o planejamento anual. A diretora geralmente o analisa para verificar se está de acordo com o projeto político pedagógico da escola. Podemos notar aí um contrassenso, pois a dinâmica do planejamento deveria vir antes da escolha do livro. O livro deveria estar a serviço do planejamento, como material de apoio e não se tornar o instrumento principal para elaboração do planejamento.

\subsubsection{O diretor do Colégio EFA}

Segundo a diretora, a escola não tem preocupação em preparar seus alunos para o vestibular da UFPR, pois os alunos não expressam a intenção de fazer o exame, pois este está muito distante da realidade vivida por eles. Devido às poucas aulas de língua estrangeira que os alunos têm na escola, devido à baixa qualidade do livro didático adotado e à falta de materiais e equipamentos 
complementares (retro-projetor, gravador, fotocopiadora (a escola ainda utiliza mimeógrafo e estêncil, por exemplo), a prova de língua inglesa do vestibular se torna muito difícil para esses alunos.

Como a Escola EFA não desenvolve um trabalho voltado para preparação do vestibular, não há, conseqüentemente, a necessidade de se buscar informação sobre o exame. As poucas informações obtidas chegaram através de jornais e opiniões de conhecidos que passaram pelo processo seletivo. Apesar do ambiente desfavorável para o preparo para o vestibular, uma das professoras tem se preocupado em trabalhar pequenos textos de livros-didáticos para seus alunos aprenderem a interpretá-los. Porém, essa atitude não é uma experiência compartilhada pelas outras professoras da escola, que preferem continuar a dar as aulas tradicionais de gramática propostas pelo livro.

A diretora não acha que o exame do vestibular possa ser um mecanismo eficiente de mudanças no ensino de inglês nas escolas do ensino médio por dois motivos: primeiro, o ensino superior público não está nos planos desses jovens. Os poucos que continuam os estudos em nível superior cursam instituições particulares da região. Segundo, o ensino de língua estrangeira acontece somente na escola pública com um número reduzido de aulas na grade escolar. Por esses motivos, a escola não vê a necessidade de se inserir no universo da preparação para o vestibular. Parece-me uma visão equivocada, pois os profissionais da escola, no intuito de preparar seus alunos para a cidadania, deveriam desenvolver programas para mudar essa imagem.

Mais uma vez, notamos que esse discurso é o mesmo da coordenadora da SEED e reproduz a ideologia de que há dois tipos distintos de cidadão: um cidadão que vai para universidade, pensa e detém o poder e as melhores posições no mercado de trabalho, e um outro que é direcionado para trabalhar em funções não qualificadas e de baixa remuneração e, assim, servir ao primeiro grupo. Mais intrigante ainda é saber que a diretora da Escola EFA é professora de história e deveria ter ciência que está reproduzindo essa visão determinista e classista.

Contudo, a diretora pensa que o ensino de língua inglesa na escola pública tem mudado, e o papel da língua estrangeira tem sido redefinido pela comunidade escolar. Segundo ela,

percebe-se que houve uma reestruturação significativa no ensino da língua inglesa. Não há como pensarmos educação sem atender às necessidades do mundo globalizado que se aponta. Porém, sua eficácia virá em nossa concepção com a contextualização já iniciada, e a 
possibilidade do aluno poder vivenciá-la cotidianamente. Nota-se que sua importância já é evidente, cabendo a cada instituição adequá-la à sua realidade e propiciar sua aplicabilidade eficiente.

Podemos notar que o discurso da diretora da redefinição da língua estrangeira na escola não condiz com o que realmente acontece em sala de aula. As aulas continuam centradas no ensino de gramática e pouca ou quase nenhuma mudança significativa pode ser percebida no planejamento e aulas de LE. Isso pode nos levar a questionar se a comunidade escolar não pratica o que prega.

\subsubsection{As percepções do professor da Escola EFA}

Apesar de a professora da Escola EFA ter formação em dois cursos de pós-graduação, além de certificados de cursos de capacitação oferecida pelo Núcleo de Assessoria Pedagógica da UFPR - NAP -, ela não prepara seus alunos para vida acadêmica. Ela descreve porque a escola não concentra seus esforços para preparar seus alunos para o vestibular:

Eu acho que a instituição tem tantos problemas (ri...) que ela não consegue ter tempo pra se preocupar com qualquer outra coisa. Em questão tanto do ensino fundamental quanto do médio ela tem tantos problemas, principalmente na questão financeira. Não temos espaço físico, nós não temos material suficiente. Falta dinheiro pra você manter um monte de coisas. A questão da disciplina, faltam profissionais, poucos orientadores, pra parte administrativa também. Então tudo isso tem que ser pensado primeiro. As prioridades são outras. A prioridade agora é a sobrevivência e não o vestibular.

Será que os outros problemas são mais importantes a serem resolvidos do que o do preparo para uma vida acadêmica? Será que, se a professora usasse o exame como um instrumento balizador para seu ensino, o 'problema' do planejamento de aulas não seria resolvido?

Os alunos dessa escola não têm uma perspectiva de vida promissora, pois a maioria é filho de agricultores ou pequenos comerciantes e o ensino superior não está em seus planos. Os poucos que se aventuram a prosseguir os estudos, o fazem em pequenas faculdades particulares, nas cidades vizinhas. $\mathrm{O}$ vestibular da UFPR para esses alunos é simplesmente um sonho. A professora não está reproduzindo o mesmo discurso determinista da diretora e da coordenadora da SEED? Nesses últimos anos, a professora não se recorda de nenhum 
aluno ter passado no vestibular da Federal. Como não há interesse por parte dos alunos em continuar os estudos superiores, a professora também não direciona seu ensino para esse objetivo. Segundo ela, "a escola pública prepara o aluno para a vida". Resta saber a que tipo de vida a professora se refere. Como é sabido, os alunos da escola pública, com nível médio completo, não conseguem boas colocações no mercado de trabalho. Nesse nível de educação, eles não são profissionalizados, nem têm conhecimento geral suficiente para atuarem em empregos mais bem pagos. Sabemos também que o desemprego nesse nível escolar é maior do que no nível superior. ${ }^{2} \mathrm{O}$ vestibular não faz parte da vida de um jovem que aspira a ter uma profissão mais qualificada e mais bem paga? Por que os alunos da escola pública são privados dessa parte da vida? Será que, se eles tivessem o mesmo nível de conhecimento que seus colegas da escola particular, eles também não almejariam ingressar na universidade? O discurso de que os alunos não têm interesse em continuar seus estudos acadêmicos é bastante conveniente, pois exime a escola pública da responsabilidade do fracasso escolar.

Portanto, já que a escola não tem como meta preparar seus alunos para o vestibular, os professores não têm interesse em procurar informações sobre o exame. Não há comunicação entre colegas, nem entre escolas. As informações, que a professora tem, vem da UFPR, uma vez que ela freqüenta alguns cursos de capacitação que a instituição oferece aos professores do Estado. Esse círculo vicioso - escola não prepara para o vestibular porque os alunos não têm interesse e vice-versa - é um raciocínio bastante equivocado. Os alunos não mostram interesse, pois sabem que não têm preparo nem conhecimento para serem bem sucedidos em exames públicos disputados, e, portanto, nem prestam o vestibular. Se a escola mudasse sua postura derrotista e começasse a preparar seus alunos para o desafio, certamente um número maior deles seguiria uma carreira universitária.

Para os professores do colégio, a prova de língua inglesa do exame de vestibular da UFPR é bem difícil. Apesar de a professora achar que essa prova contempla os conteúdos e capacidades necessárias para quem pretende usar o inglês nos cursos da universidade, ela reclama dizendo que o exame está totalmente fora da realidade dos alunos das escolas públicas e, portanto, é injusto, pois o exame "não avalia o que eles estão aprendendo atualmente". Argumento

2 QUADROS, Waldir. Desemprego e escolaridade In: Série Estudos do Trabalho: Brasil, Estagnação e Crise, GELRE Coletâneas. Disponível em: <https://www.gelre.com.br/estagnacao_ crise/desempregoeescolaridade.html>. Acesso em: $1^{\circ}$. abr. 2006. 
equivocado da professora, pois o ensino médio é que tem que melhorar seu nível e não o vestibular se equiparar a ele. Os textos da prova de inglês do vestibular da UFPR e de outros vestibulares da cidade são complexos e de difícil compreensão para essa comunidade. A professora tem consciência de que ainda trabalha muito a gramática em sala de aula, apesar de achar que a não cobrança dela no exame seja algo muito bom e inovador. Ela jocosamente comenta o fato de o exame não avaliar explicitamente a gramática:

Acho que isso é bom porque no âmbito geral nós estamos voltados para uma outra era. Então talvez fosse a questão de não ser esquecido... a gramática [ri]... pra não esquecer que ainda tem um Amadeu Marques no mercado [ri]. Eu acho que é o caminho certo. Eu acredito que seja o caminho certo. Só que ainda existem vários professores que ainda trabalham "The book is on the table.

Quando ela afirma que "o vestibular está totalmente fora da realidade dos alunos das escolas públicas e, portanto, é injusto para esses alunos, pois o exame não avalia o que eles estão aprendendo atualmente", temos a impressão que o vestibular é que tem que se moldar à escola pública e não o inverso. Há aí inversão de valores, pois se o vestibular se adequar ao nível dos alunos da escola pública, ele corre o risco de ser inadequado, uma vez que o ensino da escola pública é inadequado.

Parece que a professora está em um processo de mudanças e adaptações de seu ensino, pois fez e faz cursos de capacitação que o $\mathrm{NAP}^{3}$ oferece aos professores da rede pública. As aulas de gramática são intercaladas com interpretação de textos, pois ela acha que não somente a UFPR vem cobrando essa habilidade, mas "todos os tipos de avaliações e outras instituições também estão voltados à leitura". Ela se sente satisfeita com o enfoque na leitura, mas adverte que exige muito mais do professor em termos de preparação de aulas e conhecimento lingüístico: "na realidade você tem que pensar. Você precisa mexer mais com os neurônios pra fazer isso. A única questão é que pelo número de aulas você tem pouco tempo pra leitura, né?" Tanto o exame do vestibular da UFPR quanto os cursos feitos na UFPR fizeram-na refletir sobre sua visão de linguagem e de aprender e ensinar uma língua estrangeira. Apesar de

3 O Núcleo de Assessoria Pedagógica - NAP - é um projeto do Departamento de Letras Estrangeiras Modernas da UFPR e, além de manter banco de dados para pesquisas de professores dos vários níveis e formas de ensino, tem por objetivo oportunizar constante atualização e capacitação de professores de línguas estrangeiras. 
ela ter afirmado que sua visão de ensino está mudando, não foi possível observar essa mudança em sua prática em sala de aula. Talvez seja por causa do livro adotado - extremamente estruturalista - e o pouco conhecimento sistêmico que os alunos têm da língua inglesa. Assim mesmo, ela tenta introduzir alguns textos didáticos que são mais simples de compreender. Os textos originais da prova não são utilizados, pois são muito difíceis para os alunos.

Ao ser questionada se o exame pode ser um mecanismo eficiente de mudanças no ensino de inglês nas escolas de ensino médio, a professora assevera que o exame é um fator de conscientização de que todos nós deveríamos nos concentrar no aprimoramento da leitura tanto da língua materna quanto da estrangeira. Ela lamenta que "a nossa educação ainda não está voltada para leitura”. Ela também se queixa de ser excluída e de não ter acesso às informações importantes da prova de língua inglesa do vestibular da UFPR. Seu desejo é que os professores da rede pública sejam capacitados a compreender o vestibular e a poder trabalhá-lo em sala de aula. Para ela, o exame poderia direcionar as aulas no ensino médio para o desenvolvimento da habilidade de leitura tanto na língua materna quanto na estrangeira. Além disso, quando afirma que "os professores da rede pública deveriam ser capacitados para compreender o vestibular e trabalhá-lo em aula”, ela pode estar sugerindo que o exame deveria direcionar o ensino superior, pois, segundo ela, as faculdades de Letras deveriam capacitar os professores para tal, assim eles poderiam trabalhar esses exames nas escolas de ensino fundamental e médio. O exame deveria surtir efeito para frente, ou seja, as Faculdades de Letras deveriam capacitar seus alunos - futuro professores - a conhecerem todas as concepções de linguagem, de língua e de avaliação por trás dele.

\subsubsection{As aulas do professor da Escola EFA}

No período de 5 de maio a 23 de junho de 2003 foram observadas 13 aulas. A professora da Escola EFA dá aula para aproximadamente 45 alunos na turma que observei. Com exceção de dois alunos, a grande maioria estava muito motivada em sala de aula e mostrava uma atitude bem positiva em relação à disciplina. Apesar de a escola adotar o livro de Amadeu Marques, Inglês - Série Ensino Médio, ela pouco o utilizou durante o bimestre preferindo ou dar exercícios passados na lousa ou folhas de exercícios de compreensão de textos fotocopiadas de outros livros didáticos. A aula basicamente concentra-se na explicação gramatical que o livro sugere, aos moldes estruturalistas. Ela ensina o tópico gramatical e esquematiza o ponto na lousa. Todos alunos copiam silenciosamente. Por exemplo, ela ensinou o yes/no question do passado simples 
- Did you...? Logo em seguida, ela pediu aos alunos que fizessem os exercícios do livro sobre o assunto. Após alguns minutos, ela leu as orações e pediu aos alunos as respostas.

\section{Exercício 102}

1. American astronauts walked (g) on the moon.

2. The Second World War Stared (e) in Europe in 1939.

3. Princess Diana died (j) in Paris in 1997.

4. The Pope visited (h) Brazil in 1997

5. The Second World War ended (i) in 1945, etc.

Na aula seguinte, ela começou com um esquema na lousa:

\begin{tabular}{|c|c|}
\hline Simple Present & Simple Past \\
\hline Do (I/you/we/they) work every day? & \\
Yes, (I/you/we/they) do. & Did (I/you/we/they) work yesterday? \\
No, (I/you/we/they) don't. & Yes, (I/you/we/they) did. \\
Does (he/she/it) work every day? & No, (I/you/we/they) didn't. \\
Yes, (he/she/it) does. & \\
No. (he/she/it) doesn't. & \\
\hline
\end{tabular}

Em seguida, os alunos foram para o livro fazer mais exercícios sobre a diferença entre Simple Present e Simple Past, em itens isolados. Todas as aulas concentraram-se na gramática, bem aos moldes do Método GramáticaTradução. Em algumas aulas, a professora trouxe alguns exercícios de leitura (Anexo G.1). O primeiro texto era um texto simplificado sobre Fernando Pessoa, com exercícios simples de compreensão e vocabulário. O segundo folheto possuía seis tipos de textos diferentes e os alunos tiveram que identificar a tipologia deles. Apesar de ser atividade de leitura, foram utilizados textos didáticos, não autênticos, e os alunos não conseguiam ler quase nada. A professora teve que ler os textos em voz alta e traduzi-los para que eles pudessem resolver os exercícios. As atividades continuaram bem estruturalistas, com interpretação superficial dos textos - reconstituição de informação pontual linear. Os alunos não haviam sido preparados em aulas anteriores para desempenhar a tarefa proposta satisfatoriamente. Na verdade, não houve o ensino de leitura, mas avaliação dela através dos exercícios, já que tal habilidade não era trabalhada sistematicamente em sala de aula.

Tanto o primeiro teste quanto o segundo - feitos no estêncil - (Anexo G.3) são testes da era psicométrico-estruturalista, com avaliação de itens isolados. No segundo teste, a professora tentou contextualizar o Passado Simples fazendo 
uma atividade de preenchimento de lacunas de um texto. Mas o texto serviu de pretexto para enfatizar a gramática.

Apesar de ter dito na entrevista que sua visão de linguagem e ensino de LE tem mudado por causa dos cursos que fez, ela continua sendo estruturalista. Tal mudança ainda não pode ser notada nem sua prática de sala de aula.

As aulas da professora não favorecerão um desenvolvimento da competência lingüística suficiente dos alunos para que eles possam desempenhar qualquer trabalho no futuro, muito menos para que se tornem leitores proficientes para enfrentarem um exame de língua inglesa do vestibular da UFPR. As aulas da professora são um reflexo do descaso da SEED, da diretora e dela mesma em relação ao objetivo e propósito de se ensinar uma língua estrangeira no ensino médio.

\subsubsection{O livro da Escola EFA e as percepções de seu autor}

O livro didático Inglês: Série Novo Ensino Médio, utilizado na Escola EFA, foi escrito por Amadeu Marquês, professor que desenvolve material didático há 30 anos. Ele já trabalhou nos ensinos fundamental e médio, em escolas públicas e particulares, bem como em cursos pré-vestibulares. Hoje trabalha exclusivamente escrevendo material didático para o ensino da língua inglesa.

Para o professor/autor, saber falar a língua inglesa é tão importante quanto qualquer outra disciplina curricular. Ele justifica sua afirmativa dizendo que utilizamos essa língua na Internet e outros meios de comunicação e também pelo fato de estarmos em uma era globalizada. O domínio da língua inglesa, para ele, é uma condição sine qua non para a maior parte dos profissionais no mercado de trabalho.

Ao escrever seu material, o professor diz que desenvolve seus livros para "alunos interessados na aquisição de conhecimentos essenciais para seu desenvolvimento como cidadão e para a sua preparação acadêmica e/ou profissional". Os professores que o autor tem em mente quando escreve seu material são

profissionais conscientes da importância e responsabilidade do seu papel como educador, com generosa entrega de tempo, disposição e vontade de ajudar o aluno na árdua mas gratificante tarefa da construção do conhecimento.

Meta dificilmente atingível pelo fato de o livro ser focado em gramática. O objetivo do material, segundo o escritor, é ser "um instrumento prático e user-friendly (sic) para que professor e aluno possam atingir os melhores 
resultados, dentro dos limites impostos pela realidade". Aqui, o autor parece estar justificando as limitações de seu livro ao falar de "limites impostos pela realidade". Para atingir "melhores resultados", antes de começar a escrever o material, o escritor analisa todos os documentos oficiais, tais como PCNs, LDBEN, e qualquer outro documento que seja pertinente. Além disso, o autor afirma que se preocupa em trabalhar temas que despertem o aluno para o exercício da cidadania, para o conhecimento, debate e conscientização de assuntos que considera importantes para a sua formação como pessoa e não apenas como alguém capaz de compreender um texto escrito em inglês. Nas obras mais recentes prioriza um pouco mais a competência para a leitura e compreensão de textos. O autor ressalta:

Entendemos que, das quatro principais habilidades lingüísticas, a "reading" é a que de fato reúne as maiores possibilidades de trabalho bem sucedido, já que "writing", e, sobretudo "listening" e "speaking", tornam-se muito mais difíceis de serem conseguidas com sucesso, dada a realidade das situações da sala de aula da maioria dos professores: turmas muito grandes, desniveladas, heterogêneas e com variados graus de interesse por parte dos alunos.

O autor preocupa-se em reunir textos que, além do seu papel de fio condutor da apresentação dos aspectos gramaticais e estruturais da língua inglesa, venham de fontes diversas e tenham estilos os mais diversos. Busca materiais que exploram temas relacionados com o homem e seu lugar no mundo e na vida, de acordo com os temas transversais e as diretrizes curriculares nacionais. Porém, no livro adotado pela escola, tais preocupações não são contempladas. O índice foi construído focando pontos gramaticais, e, os poucos textos existentes são pretextos para o ensino de gramática. Além disso, nem todos os textos parecem autênticos.

O autor também afirma que a editora dispõe de um banco de exames de vestibulares de todo o Brasil, permanentemente renovado, e os autores têm acesso a qualquer exame, inclusive o da UFPR. Aqui sentimos o efeito retroativo do exame de vestibular ser exercido na editora, pois notamos que há uma preocupação de disponibilizar para os autores esses exames que podem, direta ou indiretamente, influenciá-los na elaboração do material didático. O autor afirma que seu material prepara plenamente os alunos para o exame de vestibular, seja o volume único, seja a coleção seriada, pois, segundo ele, os livros priorizam a leitura através de textos como os utilizados no exame vestibular da 
UFPR e também porque o tipo de questões desse exame, em português e inglês e em diferentes graus de dificuldade têm sido apresentados aos alunos nesses livros. Visão equivocada do autor. Seu livro concentra-se no ensino de gramática e as questões de compreensão de textos não passam do tipo de reconstituição de informações pontuais e lineares. O livro carece de uma visão de linguagem e de leitura sintonizado com as concepções atuais, e, por esse motivo, dificilmente pode atingir o objetivo de preparar o aluno para serem leitores proficientes.

Para que o aluno seja bem sucedido nos vestibulares, o autor esclarece que o desenvolvimento de leitura deveria ser iniciado desde a $5^{\mathrm{a}}$ série do fundamental e ser progressivamente trabalhado até o $3^{\circ}$ do ensino médio, pois os exames de vestibular, em geral, exigem interpretação de textos, isto é, habilidade que será exigida ao longo dos estudos no curso universitário. Uma prática impossível, pelo menos no Estado do Paraná, uma vez que não há uma seqüência coesa e coerente nem entre os ensinos fundamental e médio, nem entre os três anos do ensino médio.

Os textos usados nos exames de vestibular de língua inglesa da UFPR ora são razoavelmente fáceis, ora bem difíceis, segundo o autor. Ele também acha que os tipos de texto são bons, assim como as fontes, os estilos e principalmente o tamanho dos textos. Os assuntos são atuais, interessantes e redigidos em estilo claro. As questões são bem colocadas, sem armadilhas. Ele somente lamenta que o exame não avalia a gramática explicitamente, dizendo:

Acho que além dos textos e questões sobre eles como a prova apresenta atualmente, deveria também haver questões específicas de aspectos gramaticais e explico por quê. Todos sabemos que o conhecimento das estruturas gramaticais é fundamental para a compreensão dos textos, então quem não tiver o domínio dessas estruturas não conseguirá, em princípio, entender o texto conscientemente, mesmo que faça uso de um extenso arsenal de estratégias de leitura, na tentativa de 'adivinhar' isto ou aquilo. Ma se na prova da UFPR ou de outro qualquer exame vestibular, houver questões específicas de gramática, principalmente sobre estruturas verbais, será mais fácil ara o professor saber quais aspectos gramaticais apresentar, fixar e praticar, tendo em vista a sua ocorrência naqueles exames.

Voltar à base e avaliar a gramática da língua significa retroceder para a concepção estruturalista de língua, de ensino e de avaliação de LE. Saber sobre 
a língua não significa saber a língua. A fala do autor nos mostra que ele ainda está atrelado às concepções tradicionais de linguagem e leitura, o que explica seu livro também ser estruturalista.

Quando os vestibulares em geral começaram a exigir interpretação de textos, ao invés de avaliar estruturas linguísticas, o autor, junto com a editora, se preocupou em adaptar seus livros para as novas exigências de mercado, segundo o autor. A partir da nova exigência - vestibulares centrados em leitura - o autor afirma que procurou adequar seu material para tal necessidade.

Como ele ressalta, "nossos livros sempre apresentaram as estruturas lingüísticas de forma contextualizada, numa seqüência graduada, sempre reciclada e sempre a partir de textos". A proposta deles não é apresentar as regras gramaticais de forma estanque, separada do texto. Os aspectos gramaticais básicos da língua inglesa devem estar integrados com o texto e sua compreensão. "Gramática e texto tem um casamento indissolúvel, não há divórcio nessa sociedade". Mas, na prática, seus textos servem somente como pretextos para o ensino de gramática.

Ao falar sobre o exame e seu poder de ser um mecanismo eficiente de mudança no ensino de inglês nas escolas de ensino médio, o autor afirma que a capacidade de compreensão de textos foi há muito tempo estabelecida como principal objetivo a ser atingido pelos alunos, anterior a qualquer vestibular. Foram os vestibulares que se adaptaram à nova necessidade de se desenvolver a habilidade de leitura. Talvez o mercado de trabalho tenha tido uma parcela de influência, uma vez que manuais e documentos de muitas empresas são gerados na língua inglesa, além das universidades necessitarem de alunos que pudessem ler textos acadêmicos na LE. Talvez o mercado de trabalho e as universidades mostraram a importância do ensino de leitura nas escolas.

O autor também dá uma receita de como ser bem sucedido no vestibular:

O autor vai estabelecer um programa de aquisição e construção de conhecimentos que serão no final da estrada cobrados e verificados pelo exame vestibular. Nesse sentido, portanto, e com toda a humildade possivel, o autor apresenta um plano em função do que é necessário saber para se chegar ao sucesso no vestibular, que funciona como o grande 'cobrador'. Quem serve a quem? O autor, humilde mestre-cuca, prepara o bolo para a grande festa. Quem não souber seguir a receita direitinho, não terá bons resultados.

O livro didático de Amadeu Marques, apesar de apresentar atividades de leitura, não contempla concepções atuais de linguagem e de leitura. Dificilmente 
esse material propiciará boas oportunidades para que os alunos desenvolvam sua competência lingüística satisfatoriamente. A escolha do livro foi feita a partir do critério preço. Nem a professora, nem a diretora e muito menos a SEED se preocuparam em adotar um livro (ou preparar seu próprio material, já que os alunos são carentes e não podem comprar livros) que pudesse realmente preparar seus alunos adequadamente para o mercado de trabalho e para a vida acadêmica. Não há preocupação com o fato que os alunos necessitam de aulas e materiais didáticas sintonizados com as novas concepções de linguagem e ensino de LE; que eles necessitam documentos oficiais e currículos bem elaborados, professores capacitados e uma estrutura escolar bem estabelecida. Na verdade, o que essa comunidade realmente necessita é de uma política de educação coerente e responsável, comprometida com os jovens das escolas públicas.

\subsubsection{Os alunos da Escola EFA}

Os alunos da Escola EFA vêm da zona rural de Quitandinha e têm idade entre 16 e 19 anos. Muitos são filhos de agricultores ou de funcionários públicos. Mais da metade da turma trabalha ou no comércio local ou nas lavouras dos pais e avós para complementação orçamentária familiar. Dos 38 alunos que responderam ao questionário nenhum faz curso pré-vestibular junto com o terceiro ano do ensino médio. Alguns gostariam de fazer cursos pré-vestibulares, mas não têm certeza se irão conseguir pagar um curso. Outros preferem fazer cursos de informática ou inglês para poderem começar a trabalhar logo depois de concluírem o ensino médio. Todos têm instrução de inglês da $5^{\mathrm{a}}$ a $8^{\mathrm{a}}$ séries do ensino fundamental e dois anos no ensino médio, mas o conhecimento da língua é bem fraco. A grande maioria sabe que tem poucas aulas de língua inglesa no ensino médio e que essas aulas proporcionam somente o básico da língua, o que constitui uma barreira para os alunos que pretendem prestar vestibular em instituições públicas. Eles também ressaltam que o inglês aprendido na escola não lhes permitirá sair-se bem em futuras profissões. Como disseram alguns alunos:

- No colégio, eu estudo sete anos de inglês. Aprendi pouco, pois não há oportunidade para falarmos e nem os professores sabem falar a língua corretamente.

- Eu não aprendi até hoje falar inglês e já são sete anos. Nesses sete anos já era pra 'tá falando muito bem inglês.

- Até hoje posso contar nos dedos as palavras que sei falar em inglês. 
Nenhum aluno teve aulas de inglês em institutos de línguas, pois não há na cidade escolas de idiomas. Além disso, o fraco desempenho da escola pública no ensino da língua inglesa faz com que a comunidade pense que a aprendizagem de uma língua estrangeira não é necessária ou importante. Alguns depoimentos dos alunos ilustram isso:

- As pessoas de minha comunidade acham necessário, interessante, mas a maioria vê como uma coisa distante, longínquo, difícil de se conseguir.

- Acho que o inglês exelente (sic) é importante e concerteza (sic) muito necessário porque muitos trabalhos exigem o curso de inglês.

- As pessoas da comunidade acha (sic) que o inglês não é importante porque é uma coisa muito difícil.

- A comunidade acha que não tem importância.

- Não sei o que a comunidade penção (sic).

- O inglês concerteza (sic) é necessário, porquê (sic) conforme o trabalho é necessário uma pessoa que saiba falar inglês.

- Eu não sei o que eles penção (sic) por que esse idioma nem é falado aqui.

- Pessoas da zona rural não têm importância para ela.

- Pra que vou aprender a falar inglês se vou plantar batata a vida inteira?

- Por que aprender inglês se vou ficar mesmo no meio do mato?

Por não almejarem estudar na UFPR, os alunos nem procuram informações sobre o vestibular. Foi unânime a frase: não tenho nenhuma informação sobre o vestibular. Outros comentários foram:

- Nem sei nada sobre o vestibular da UFPR detalhadamente, só sei que é muito concorrido.

- Não sei nada, mas é muito concorrido.

- Não conheço a UFPR.

- As informações são poucas.

- É muito difícil.

- A única coisa que sei é que a inscrição se não me engano é de $R \$ 75,00$ e a faculdade é grátis, caso passe no vestibular.

A Universidade Federal do Paraná é tão distante da realidade dessa comunidade que os alunos ou não conhecem a instituição ou nem fazem o vestibular 
por saber que esse exame está muito além de suas capacidades. Ao serem questionados sobre suas opiniões da prova de inglês da UFPR, a grande maioria não opinou por nunca ter visto uma prova do vestibular da instituição. Uma pequena parte disse que a prova é muito difícil. Os alunos disseram que sua professora tentava prepará-los da melhor maneira, ensinando-lhes gramática - pois o livro é gramatical -, e às vezes interpretação de textos. Tal esforço, porém, não era suficiente para que eles pudessem ser bem sucedidos no vestibular.

Ao serem indagados se achavam que o exame pode ser um mecanismo eficiente de mudança no ensino de inglês nas escolas públicas de ensino médio, a grande maioria deles nem sequer compreendeu a pergunta. Somente duas alunas ressaltaram que caso o exame influenciasse o ensino médio, "as escolas iriam, cada vez mais, se aperfeiçoando na língua inglesa". Um outro aluno disse que "através do exame podemos ver se o aluno se aperfeiçoa na escola".

Como o vestibular não é uma meta para essa comunidade, os alunos não vêem nenhuma importância em aprender a língua inglesa, nem em se preparar para qualquer vestibular, seja em, em instituição pública ou particular. De todas as escolas que observei, a Escola EFA foi a que mais me causou impacto, pois apesar dos jovens parecerem ter vontade de aprender, são os que têm menos perspectivas de um futuro acadêmico.

Os alunos não têm grandes expectativas em relação às aulas de língua inglesa na escola, pois conhecem a realidade precária da escola pública. Eles têm consciência de que os professores não têm a capacidade necessária para que eles possam aprender a língua e estão conformados com a impossibilidade de prestar o vestibular por falta de conhecimento e preparo.

Neste cenário, pudemos notar que o exame de inglês da UFPR é considerado difícil tanto pela diretora, como para a professora e os alunos. A diretora e professora atribuem o baixo nível das aulas de inglês à infra-estrutura degradada da escola pública e ao desinteresse dos alunos pela disciplina. Os alunos, por sua vez, afirmam que não aprendem inglês porque a escola não oferece um ensino de qualidade. Nem a diretora nem a professora acham que o exame possa ser um mecanismo eficiente para balizar o ensino da língua inglesa na escola. Alguns alunos, ao contrário, disseram que se o exame desse um norte ao ensino da língua, eles conseguiriam aprendê-la. O discurso da diretora e professora ajuda a alimentar a contradição que o ensino público não prepara o aluno para atingir a fase final do ensino público: o ensino superior público. Relegar o ensino de uma disciplina por embasá-lo na concepção de que esses alunos não querem ou não precisam aprendê-la é fortificar a hierarquização dos saberes, ou seja, somente um determinado grupo com melhores 
condições sociais é que tem o direito ao conhecimento. O processo de sujeição dos alunos da escola pública é poderoso. Porém, há, como pudemos observar em suas falas, um sentimento de indignação e consciência de que são privados de uma educação de qualidade. Esse sentimento pode ser o primeiro passo para que eles lutem por uma escola realmente democrática e igualitária. Como afirma Matsuura, ${ }^{4}$ diretor-geral da Organização das Nações Unidas para a Educação, a Ciência e a Cultura (Unesco),

temos que prover uma escola que forme e informe. Além disso, a qualidade dever ser julgada pelo espelho da igualdade. Se existe uma escola para pobres e outra para ricos, a qualidade está afetada, na medida em que ela faz diferença para um amplo espectro de objetivos individuais e coletivos, que vão desde o cuidado com a saúde até o aumento da renda.

Atualmente, as autoridades da área da educação enaltecem o fato de 98\% das crianças entre 7 e 14 estarem matriculadas em uma escola. Mas que tipo de escola? A foto do trem da Índia que abre este capítulo serve como uma metáfora da escola pública brasileira: abriga todos em condições totalmente precárias. Precisamos de uma escola de verdade.

\subsection{ESCOLA PÚBLICA URBANA}

A escola pública urbana de Curitiba (doravante Escola LC) é uma escola com uma grande heterogeneidade de alunos. Pela manhã, ela é freqüentada por alunos das classes C e, à noite, por alunos das classes D e E, ou seja, jovens trabalhadores ou desocupados. Diferentemente da escola pública rural, a Escola LC oferece duas horas semanais de língua inglesa nos três anos do ensino médio, além de dispor de revistas, jornais e fitas de vídeo.

\subsubsection{O diretor da Escola LC}

O diretor-aulixiar e também professor de matemática da Escola LC possui o mesmo discurso que os sujeito Escola E. F. A e coordenadora de inglês da SEED. Ele diz que os alunos têm ciência de sua condição precária de estudo e, por essa razão, não almejam prestar o vestibular da UFPR, como afirma:

4 MATSUURA, Koichiro. Boa escola é a que estimula. Artigo publicado no O Globo dia 08 de novembro de 2004. Disponível em: <http://www.unesco.org.br/noticias/opiniao/artigom/desafios/mostra_documento>. Acesso em: 31 ago. 2006. 
A gente percebe que quando nós falamos em Federal eles já acham que é só pra elite e pro pessoal dos cursinhos e de escolas particulares que têm mais chances. Então, com isso eles já desistem, nem se inscrevem pra fazer o vestibular porque sabem que estão bem à margem da disputa pelas vagas.

O livro da Editora IBEP foi adotado nessa escola, por ser o mais barato das livrarias. Para aqueles que não podem comprar o livro, a biblioteca empresta alguns exemplares. Os professores utilizam o livro à risca, apesar de o diretor dizer que eles seguem uma pedagogia crítica. Assim, os professores junto com a coordenação e a própria direção, orientam-se pelo próprio regimento da proposta pedagógica da escola, e fazem o planejamento anual. Discurso bom, prática diferente. Se olharmos o planejamento anual (Apêndice H. 3 e H. 4), vemos que o documento está longe de "seguir uma pedagogia crítica". O índice do livro transformou-se, no planejamento, nos conteúdos a serem trabalhados.

Apesar de falar de "uma pedagogia crítica", a escola tem ciência da incapacidade de seus alunos enfrentarem o vestibular da UFPR, como comenta o diretor:

.... que a gente percebe é que os alunos do ensino médio, como o pessoal dos terceiro anos, têm aversão, eles têm muita dificuldade em interpretar os textos. E no vestibular é o que eles vão precisar.

Por esse motivo, a instituição não tem a preocupação de preparar seus alunos para o exame. Como na Escola EFA, o diretor da Escola LC usa o discurso de que "os alunos não têm interesse em continuar os estudos superiores, e por esse motivo não preparamos para o vestibular", para eximir a escola pública da responsabilidade do fracasso escolar.

Ainda que a escola não tenha como objetivo preparar seus alunos para o vestibular, o diretor-auxiliar e alguns professores têm informações sobre ele através dos jornais. Esse interesse existe, pois tanto o filho do diretor-auxiliar como o da professora estudaram em escolas particulares e prosseguiram na vida acadêmica.

O diretor-aulixiar, que tem acompanhado a trajetória do vestibular da UFPR nos últimos anos, comenta:

Basicamente eu venho acompanhando o vestibular da UFPR há 20 anos. E quando passou a ser a somatória, no início eu achei um pouco estranho, né?... mas depois percebi que o aluno que estuda ele tem muito mais chance realmente de ser bem sucedido porque ele 
vai realmente premiar o aluno que tem não só conhecimento, mas também através do raciocínio dele, ele consegue resolver a maioria das questões.

O professor acha que o vestibular seleciona bem seus candidatos e afirma que somente aqueles alunos que tiveram acesso às escolas particulares e cursos pré-vestibulares são os que têm real preparo para enfrentar o exame. Afirmação inusitada, pois, de antemão, já sabe que seu trabalho e de seus colegas, na escola pública, não capacitarão seus alunos para "o real preparo para enfrentar o exame".

Ele também pensa que a prova de língua inglesa é muito mais difícil que a de espanhol. Porém, sua opinião sobre o exame, no geral, é de que as provas são muito bem elaboradas, e os candidatos têm que, primeiramente, interpretar as questões para poder responder adequadamente. Ele mostra sua frustração com relação à escola pública quando diz que "realmente o aluno tem que interpretar depois responder às questões. Acho que é o melhor caminho, né? Só que nós, infelizmente, nas escolas estaduais, o aluno não está preparado pra interpretar o texto depois responder às perguntas".

Além da falta de perspectiva de possibilitar o ingresso de seus alunos nas universidades públicas, o professor lamenta que não tenha nenhuma oportunidade de discutir o exame do vestibular da UFPR com ninguém. Ele acha que o candidato aprovado no exame "consegue interpretar e usar a gramática. Ele vai se preparar para enfrentar o seu curso tanto na universidade como na vida prática". A percepção do professor sobre "quem se prepara para o vestibular também está pronto para a vida" é bastante coerente, pois, dada a função social da leitura, se um candidato consegue desenvolvê-la para ser bem sucedido no vestibular, também utilizará tal habilidade em outras situações reais de vida. Além disso, para ele o vestibular poderia ser um mecanismo eficiente de mudanças no ensino das escolas de ensino médio. Porém, não é o que ocorre como pode ser percebido pela sua fala:

Hoje através da $L D B$, através dos Parâmetros Curriculares há uma divergência, né? O governo Federal e o próprio governo Estadual estão preocupados em preparar o cidadão para o trabalho e não pro vestibular. Então, ele está terminando o ensino médio... o aluno fica em crise. Ele não está preparado nem para o trabalho nem para fazer o vestibular. Então a gente percebe facilmente que os alunos, até alguns chegam a se revoltar, né? Porque as escolas particulares preparam para o vestibular, não se preocupando para o trabalho e nós 
das escolas estaduais nem preparamos para o trabalho nem para o vestibular. É um conflito entre eles.

Na verdade, a visão do diretor de que 'as escolas particulares não preparam para o trabalho' é equivocada. Quando um aluno termina o ensino médio em uma escola particular que se preocupa em desenvolver a leitura, por exemplo, estará apto a desempenhar funções de trabalho que exijam tal habilidade. As escolas particulares concentram-se em preparar seus alunos para o trabalho qualificado de médico, engenheiro, professor etc., ao passo que o discurso da escola pública declara preparar o aluno para o trabalho, mas não define que tipo de trabalho. Certamente ela não educa para o trabalho qualificado.

O diretor observa que a instituição não tem preocupação formal em preparar seus alunos para a vida acadêmica. As escolas seguem as orientações oficiais, elaborando as propostas pedagógicas baseadas nas LDB e PCNs com o objetivo último de "formar o jovem para o trabalho". Mesmo que a escola não tenha como meta colocar seus alunos nas universidades públicas, esporadicamente um ou dois alunos conseguem ingressar no ensino superior. Um ou outro professor trabalha com questões do vestibular. O diretor relatou que uma professora de inglês do terceiro ano noturno do ensino médio, no ano anterior, trabalhara continuamente com textos por causa do vestibular. Porém, essa não é a tendência entre os professores, pois a grande maioria não tem como objetivo preparar seus alunos para o vestibular. Portanto, nenhuma ação é tomada pelos professores, tanto em relação ao material didático escolhido, quanto à metodologia aplicada em sala de aula. As aulas de inglês, em específico, são geralmente aulas de gramática que 'não inspiram muita motivação entre os alunos', segundo o diretor.

É interessante a fala do diretor quando relata como os professores de língua inglesa trabalham em sala de aula:

No geral não só da língua estrangeira, o professor continua a trabalhar de acordo com a LDB e PCNs trabalhando a interdisciplinaridade das matérias e não tem aquela preocupação com o vestibular. Eles acham que o aluno está muito longe do vestibular da Federal.

O discurso oficial da escola está bem longe do que foi observado em sala de aula. Ao invés de ver um trabalho com atividades interdisciplinares, baseado na LDB e nos PCNs, o que se percebeu foram aulas direcionadas pelo livrotexto, aulas estas estruturalistas e descontextualizadas. Não se viu, em nenhum momento, nenhuma atividade interdisciplinar. Mais uma vez, o aspecto da interdisciplinaridade existe somente no discurso. 


\subsubsection{As percepções do professor da Escola LC}

Quanto à importância em aprender a língua inglesa, a professora da Escola LC tem uma visão bem crítica de seus alunos, que são na maioria das classes C, D e E: "a maior parte deles, são pessoas desencantadas com a vida e acham que o inglês só atrapalha a vida deles, porque eles não vislumbram um futuro muito promissor." Atribuir a desmotivação dos alunos pelas aulas de inglês ao "desencantamento da vida" é, no mínimo, perigoso. Segundo a professora, após terminar o ensino médio, somente uma pequena parcela dos alunos da manhã e da tarde vai fazer o cursinho pré-vestibular. São poucos os que mostram interesse por cursos pré-vestibulares depois de terminar o ensino médio e procuram por eles. Por terem consciência de seu baixo nível escolar, eles reservam um ano somente para tentar tirar o atraso que a escola pública lhes impôs. A professora comenta que:

Você não pode lutar com um sistema desse... você sozinho. Então, quando o sistema começou a pressionar muito para ter aprovação 100\% o que você faz? Você vai dar murro em ponto de faca? Você baixa o nivel. Pra você conseguir uma aprovação melhor. Todos nós fizemos isso, inclusive eu, não estou me excluindo disso. Então, com isso a gente provocou uma insegurança nos alunos. Pela insegurança eu já ouço eles falarem isso... Muito raro você ouvir: eu vou fazer o terceirão em outro lugar... Muitos poucos falam isso.

Ela assegura que a maioria não tem a "mínima vontade de aprender a língua", uma vez que não pode haver reprovação na disciplina de inglês, e pensa apenas em "passar de ano e obter o diploma". Segundo ela,

[...] o nível da língua inglesa nas escolas públicas desceu demais!!! Então você não consegue... Parte-se do princípio assim: há professores que acham o seguinte - que não é o meu caso - como [a disciplina do inglês] não reprova "porque que eu vou me esmerar?" É um oba-oba. Os alunos falam um termo incrivel: LIÇÃO. Esse termo me deixa assim chocada. "Que lição a gente vai fazer hoje?" Porque eles são ainda daquele tipo de fazer lição. Os professores deixam rolar, dão qualquer nota. O guri mesmo falou: 'Fazemos umas provinhas.' Eles mesmos acham que são provinhas... mas como lhes cai bem, né? Eles passam. Então eles não falam nada pro professor... Eles vão falar de mim. O dia que eles tirarem nota baixa, vão dizer que eu é 
que não dei aula, que não ensinei, entendeu? Mas enquanto o professor age dessa forma, lhe dando uma nota que eles precisam, oito, nove... 'tá tudo bem. O aluno também é conivente com a situação. E alguns professores, eu tenho certeza, pensam assim: não reprovam e no final do ano tem que arranjar tudo pra passar. Só aqueles casos bem desesperadores são reprovados. Porque vários alunos meus reprovaram em inglês e em nenhuma disciplina os professores deixam o aluno preso. Ele passa.... passa por conselho.

A professora, bem descrente de sua situação dentro do sistema escolar, joga a responsabilidade pelo fracasso escolar nos alunos: "o aluno também é conivente com a situação", na estrutura escolar que impede a reprovação: "o inglês não reprova .... É um oba-oba", e nos colegas: "e alguns professores, eu tenho certeza, pensam assim: não reprovam e no final do ano tem que arranjar tudo pra passar". No entanto, se analisarmos o planejamento da disciplina, escrito por ela e seus colegas, veremos que o problema não reside somente nas três fontes citadas pela professora. Pude observar, através do planejamento anual da disciplina e através de suas aulas, que ela tem uma visão estruturalista de concepções de língua e ensino de LE. Gramática e tradução são ensinados segundo moldes do antigo do Método Gramática-Tradução.

Para poder atender os alunos que não podem comprar livros escolares, os professores da escola resolveram adotar o livro "Essential English" do IBEP, por ser o mais barato do mercado na ocasião da escolha. Às vezes, a professora complementava suas aulas com textos didáticos tirados de outros livros didáticos. O livro didático direciona o planejamento das aulas: o livro é dividido em três partes e cada parte é ensinada a cada ano do ensino médio. Segundo a professora, a escola não tem nenhuma participação no planejamento das aulas, e os professores têm total liberdade para desenvolvê-lo. Informação desencontrada com a do diretor-auxiliar que afirmou que as coordenadoras e orientadoras elaboravam o documento junto com os professores. Mas indo ao encontro do que disse o diretor-assistente, a instituição, segundo ela, também não tem nenhuma intenção de preparar os alunos da escola pública para prosseguirem os estudos em nível superior. Ela protesta dizendo:

A escola, com o Jaime Lerner.. ele conseguiu subjugar as escolas ao modelo dele. Então por parte da direção da escola já sai aquele julgo, né? Então você tem que fazer como reza a cartilha: os alunos não vão pro vestibular, eles vão trabalhar. SÃO POBRES!!! É isso! 
Comentário bastante contundente da professora. Ela afirma que pelo fato dos alunos serem "pobres", eles não vão ser preparados para o ensino superior e que essa determinação vem da Secretaria de Educação.

A professora acha interessante que a prova de língua inglesa avalie a interpretação de textos, uma vez que será a habilidade utilizada pelos cursos da universidade. Ela dá como exemplo seu filho, que cursa Medicina na instituição e necessita ler e interpretar textos em inglês em várias disciplinas. Por achar os textos do exame difíceis para os alunos do colégio, ela não trabalha nenhuma atividade parecida em sala de aula, pois afirma que seus alunos não iriam entendê-los. A gramática deve ser ensinada com rigor, segundo a professora, pois "sem o conhecimento da gramática fica inviável a compreensão exata do texto", o que revela sua visão estruturalista do ensino de LE. Ela reclama que não possui recursos de materiais como jornais, revistas, livros e vídeos. Os poucos equipamentos existentes sumiram ou necessitam de manutenção. Outra informação que contradiz a do diretor-assistente - os professores e alunos têm acesso às revistas, jornais, fitas de vídeo -, enquanto ela assevera que não há material para se trabalhar.

Ao falar sobre sua concepção de linguagem e de aprendizagem/ensino de uma língua estrangeira, ela afirma que os textos sempre foram uma parte integrante dos livros didáticos, tanto de língua materna, quanto de língua estrangeira. Mas por força da circunstância foram relegados a segundo plano, ou totalmente banidos da sala de aula. Um contrassenso, uma vez que ela tem o poder de fazer seu próprio planejamento da disciplina, e não precisaria relegar a leitura. Resta saber qual é a 'força da circunstância' que ela alega impedir seu trabalho com a leitura.

Como os alunos não têm a intenção de prestar vestibular para as universidades públicas nem as professoras nem a instituição preocupam-se em prepará-los para tal. Outra vez, o mesmo discurso dos profissionais da Escola E.F. A. e do diretor-assistente da Escola LE. O vestibular não é discutido entre os professores e, segundo a professora, "se nem as próprias provas de rendimentos são discutidas que dirá do exame". Ela reclama da falta de informação sobre o exame. Os professores, aliás, dizem não terem nenhum acesso às informações sobre o vestibular da UFPR. Ela se queixa do distanciamento da escola pública em relação à UFPR, dizendo:

Não se consegue nenhuma informação. Não se precisa mais conseguir porque durante o governo Lerner ele passou a seguinte informação: nossas orientadoras e coordenadoras, supervisoras, bom... agora é tudo coordenadora (tem que dar conta de TUDO, disciplina, planejamento, elas COITADAS, elas nem sabem mais o que vão fazer). 
Durante o governo de Jaime Lerner nossas coordenadoras foram DOUTRINADAS pra passar o seguinte recado: Escola pública, principalmente para aqueles que chegam ao ensino médio, precisa preparar PARA O TRABALHO! Ele NÃO VAI fazer uma universidade!!! Ele vai depois. Primeiro ele vai trabalhar. Então temos que preparálos e dar coisas práticas, do dia-a-dia, praticidade em tudo, em todas as disciplinas. É pro aluno prático entrar no mercado de trabalho. Eles precisam muito dessa prática e não tanto do conhecimento..... OLHA O ABSURDO DA COISA!!! Como se uma coisa não estivesse relacionado com a outra. Então o Jaime Lerner conseguiu... a gente rezar a cartilha direitinho... a gente fica só olhando... a gente vai preparar nossos alunos só para o trabalho. Então antes disso, a Universidade Federal mandava questionário que a gente respondia... pra eles terem uma noção do que a gente fazia... agora não. Não mais. Acabou. O nosso relacionamento com a universidade não existe. A única coisa que as universidades fazem é mandar estagiários para observar as nossas aulas e dar uma praticadinha. Esse é o relacionamento. Não tenho nada positivo para lhe dizer sobre isso.

Mais uma vez, o discurso político da professora não condiz com que foi dito por ela mesma, ou seja, os professores têm a liberdade de elaboraram seus próprios planejamentos. Se ela tem esse poder, então ela nem precisaria 'rezar a cartilha' do governador da época. E, além disso, ela é consciente da contradição das instruções pregadas pela Secretaria - "olha o absurdo da coisa" -, ao se referir à determinação de ensinar para o trabalho e não para o vestibular. Como se o conhecimento ensinado para o trabalho não fosse o mesmo para os que seguem carreira acadêmica. Tendo essa visão clara do ensino para o trabalho e vestibular, ela deveria direcionar suas aulas para atividades inseridas na era comunicativista, o que nunca foi observado em suas aulas.

Ao ser questionada se o exame pode ser um mecanismo eficiente de mudanças no ensino de inglês nas escolas de ensino médio, ela afirma que o vestibular já causou influência no ensino, no passado, mas atualmente não causa mais nada.

A professora mostra uma visão bastante derrotista. Ela diz que se a Secretaria quer assim, então, assim será. Ela sabe criticar as determinações e pontuar muito bem onde ocorrem as falhas. Porém, os professores têm total autonomia para elaborarem seus planejamentos e ensinar o que querem. Ela mesma desconsidera as determinações e dá aulas de gramática e tradução, pois se ela fosse preparar seus alunos para o trabalho, as aulas jamais poderiam seguir concepções de ensino tão antigas assim. 


\subsubsection{As aulas da professora da Escola LC}

A professora da Escola LC usa o livro do IBEP - Essential English. O livro foi dividido em três, para atender os três anos do ensino médio. O livro segue a tradicionalíssima metodologia Método Gramática-Tradução, e o professor segue o livro ipsis litteris. Em uma das aulas, a professora escrevia na lousa o conteúdo abaixo enquanto os alunos ou dormiam ou faziam lição de outra disciplina ou simplesmente conversavam entre si. O conteúdo que a unidade 26 (p. 194) propõe é pronome adjetivo e substantivo. Ela escreveu na lousa:

\begin{tabular}{|c|c|}
\hline Pronomes adjetivos & Pronomes substantivos \\
\hline Possessive adjectives & Possessive pronouns \\
\hline My (1 ${ }^{a}$ p.s.) & mine ( $1^{\mathrm{a}}$ p.s. $)$ \\
\hline Your ( $\left(2^{\mathrm{a}}\right.$ p.s. $)$ & yours ( $2^{\mathrm{a}}$ p.s.) \\
\hline His ( $3^{a}$ p.s.) & his ( $3^{\text {a }}$ p.s.) \\
\hline Her ( $3^{\text {a }}$ p.s. $)$ & her $\left(3^{\text {a }}\right.$ p.s. $)$ \\
\hline Its ( $3^{\mathrm{a}}$ p.s.) & its ( $3^{\mathrm{a}}$ p.s. $)$ \\
\hline Our ( $1^{\mathrm{a}}$ p.pl.) & ours ( $1^{\mathrm{a}}$ p.pl.) \\
\hline Your ( $2^{\text {a }}$ p.pl.) & yours ( $2^{\text {a }}$ p.pl.) \\
\hline Their ( $3^{\mathrm{a}}$ p.pl.) & theirs ( $3^{\mathrm{a}}$ p.pl.) \\
\hline
\end{tabular}

Logo em seguida, ela leu o que escreveu e traduziu tudo para o português, inclusive a categorização das palavras - primeira pessoa do singular, por exemplo. Assim que terminou a parte de tradução ela ditou algumas orações em português e pediu que os alunos as passassem para o inglês - o MGT na íntegra.

\section{Exemplos:}

1. Ele está ainda na minha sala de aula.

Pronome adjetivo ou substantivo

Possessive adjective

Tradução: He is still in my classroom.

1. Ela nunca ajuda nossos irmãos.

Tradução: They never help our brothers.

2. Ela sempre dirige o carro dele.

Tradução: She always drives his car. 
A professora ditou cada oração e logo em seguida deu a tradução. Somente uma aluna copiou o que ela escreveu na lousa e o que ela ditou. Os outros não fizeram nada. Ela continuou a aula com mais duas orações:

1. Este carro é seu?

(seu carro)

Tradução: This car is yours.

2. Estes lápis são dela?

Tradução: Are these pencils hers?

Assim que terminou de ler as orações no português e no inglês, a professora pediu aos alunos a tarefa da página seguinte (p. 196), para o encontro subseqüente. No final da aula, havia um ar de insatisfação total. Na aula seguinte, nenhum aluno havia feito a tarefa. Durante os dois meses em que assisti às aulas, nunca nenhum aluno fez tarefa. Era visível que nem os alunos não gostavam da professora e suas aulas e nem a professor gostava de dar aulas para aqueles alunos. Uma experiência triste e desconfortável.

As provas da professora, que somente possuíam itens de pontos isolados, eram embasadas na era psicométrico-estruturalista, com itens gramaticais e traduções. A única avaliação de interpretação de texto ocorreu no final do bimestre com um texto não autêntico, e com perguntas de múltipla-escola, V/F ou achar a seqüência da oração. Exercícios típicos da era psicométrico-estruturalista (Anexo H.2). A prova espelhava as aulas da professora - pois ambos concentram-se em itens isolados da língua -, mas está longe de ser um instrumento de avaliação inserido no paradigma comunicativo.

Por se tratar de aulas para alunos do $2^{\circ}$ ano do ensino médio, as atividades propostas, os materiais usados e as avaliações estão muito aquém para quem tiver a intenção de fazer uma prova de inglês do vestibular da UFPR. As aulas estruturalistas típicas do Método de Gramática e Tradução não oferecem a mínima condição aos alunos de aprenderem a língua estrangeira, seja para o trabalho, seja para o vestibular.

\subsubsection{O livro do Colégio LC e as percepções de seu autor}

O autor do livro do IBEP - Essential English - elabora material didático há 30 anos. Graduou-se pela Universidade de São Paulo e lecionou em escolas públicas e particulares no Estado de São Paulo. Atualmente trabalha somente 
no desenvolvimento de livros didáticos para o ensino de língua inglesa nas Editoras IBEP e Nacional.

Esse autor escreve, basicamente, para alunos de escolas públicas. Os professores que utilizam o livro são profissionais da rede pública do Brasil e, em geral, com uma formação média da língua estrangeira. O objetivo do material didático, segundo o autor, é dar condições ao aluno de aprender o essencial da língua inglesa através de pequenos textos simples e do ensino da gramática fundamental do inglês. O livro faz uso de textos didáticos simplificados. Portanto, se o professor que utiliza o material achar necessário, ele deverá recorrer a materiais complementares quando o nível dos alunos ultrapassar o que o material oferece. O que norteia os objetivos dos livros escritos por ele é sua experiência pessoal em escolas públicas e consultas a outros livros nacionais e estrangeiros. Ele afirma que seu material não objetiva preparar os alunos para o vestibular - uma vez que somente $15 \%$ dos alunos de escolas públicas prestam vestibular -, mas dar apenas noções básicas de inglês. Como os diretores e professores das escolas públicas, ele compartilha da opinião de que não é preciso preparar seus alunos para esse exame, já que poucos se interessam por ele - pelo menos é o que eles acham (ver comentários dos alunos!). Mesmo assim, ele acha que vestibulares que avaliam compreensão de textos despertam nos alunos e professores o interesse pela leitura e ampliação de vocabulário. Ele tem pouca informação sobre os vestibulares e as que chegam até ele vêm por meio de jornais e revistas. De qualquer forma, ele acha que os textos utilizados nas provas de língua inglesa do vestibular da UFPR são razoavelmente fáceis para quem desenvolveu anteriormente a capacidade de compreender textos em inglês. O autor também ressalva que o exame é um bom mecanismo de avaliação uma vez que "testa a capacidade dos alunos de entender textos em inglês, o que vai auxiliá-los em leituras de pesquisas enquanto estiveram na faculdade e depois na vida."

O autor pensa que o exame de vestibular é um mecanismo eficiente de mudanças no ensino de inglês nas escolas de ensino médio, tanto que forçam as escolas, professores, alunos e editoras a darem mais importância à leitura e compreensão de textos na língua estrangeira - ideia contrária ao que foi dito no começo da entrevista, pois ele afirmou que não prepara alunos [da escola pública, pois são eles que compram seu livro por causa do baixo preço] para o vestibular. O autor assevera que as próximas obras a serem publicadas direcionarão suas atividades para o ensino de vocabulário e compreensão de textos mudando, portanto, o enfoque dos conteúdos, seleção e seqüência de atividades e metodologia.

Analisando o livro, podemos notar que o autor possui uma concepção de linguagem e ensino de LE tradicional, da época do Método Gramática-Tradução. 
Nele constam exercícios de gramática e tradução, e os textos servem de pretexto para o seu ensino. O autor se contradisse quando, no início do questionário, afirmou que não escrevia para alunos interessados no vestibular, mas no final dele disse que a habilidade de leitura deveria ser mais trabalhada em sala de aula. Seu discurso é igual aos outros professores de diretores das escolas públicas: não focaliza o preparo para o vestibular, pois os alunos não têm interesse em prosseguir os estudos em nível superior.

\subsubsection{Os alunos da Escola LC}

Os alunos do $2^{\circ}$ ano do ensino médio noturno da Escola LC têm entre 15 e 24 anos. Apesar da turma ser numerosa - 45 alunos matriculados -, nunca mais de 20 alunos compareceram às aulas nos dois meses de observação. Dos 21 alunos que responderam ao questionário, 16 deles, a grande maioria, pretende fazer curso pré-vestibular no ano seguinte para tentar os vestibulares da cidade. Informação totalmente contrária àquela dada pelo diretor-assistente e pela professora. Apenas quatro desejam fazer cursos profissionalizantes como, por exemplo, enfermagem ou administração pós-médio. Metade dos alunos que respondeu ao questionário trabalha. Havia um seminarista, duas empregadas domésticas, balconistas no comércio local e quatro rapazes que eram reconhecidos pela turma como traficantes, que se recusaram a responder ao questionário. Um dos alunos, ao falar sobre seu trabalho, deu o seguinte depoimento: "Trabalho porque quero dar uma vida melhor que a minha para o meu filho, dar o que meus pais não tivero (sic) condições de me dar quando eu era pequena". A maioria estuda a língua inglesa desde a $5^{\mathrm{a}}$ série do fundamental. Poucos têm mais anos de estudo da língua. Eles sabem que o inglês aprendido na escola pública não é suficiente para que eles possam prestar qualquer vestibular da cidade, seja pública, seja particular. Uma aluna salienta que "o inglês aprendido na escola é básico e não transmite muito conteúdo prático." Ela também lamenta que "sua professora não é boa, pois ela não tem paciência, além de responder estupidamente aos seus alunos." Uma outra reclama que "até agora ela não havia aprendido nada." Metade deles também acha que o inglês aprendido na escola ou no curso pré-vestibular não oferecerá condições para que eles possam utilizar a língua nas futuras carreiras. Fica claro que a expectativa dos alunos em relação às aulas de língua inglesa não corresponde à da professora e ao que é ensinado em sala de aula. Fica claro também que sua expectativa em relação às aulas de cursos pré-vestibulares também não corresponde às suas necessidades de trabalho. A outra metade, porém, pensa que com seu conhecimento lingüístico dá para "quebrar um galho", se for necessário utilizar a 
língua no trabalho. Somente três alunos da turma estudam inglês em institutos de línguas que são mais acessíveis à classe média. Mas a maioria foi unânime em afirmar que o inglês é importante para quem quer crescer na carreira. Um deles afirmou: "é necessário até para você arangar (sic) um emprego". Alguns lamentam saber da necessidade de aprender a língua, mas não têm condições financeiras para isso, como disse a aluna: "é necessário, mas não tem condição de pagar." Alguns acham que, dependendo da profissão, a língua estrangeira não é necessária.

Quando distribui o questionário para investigar suas percepções sobre a prova do vestibular da UFPR, senti que muitos alunos apresentaram atitudes hostis, como riscar as questões, escrever "não sei" ou ainda deixar tudo em branco. Um fato inusitado ocorreu quando lhes foi perguntado qual é o papel do vestibular da UFPR em suas vidas. Muitos simplesmente ou riscaram a questão ou não responderam. No entanto, um dos alunos, sentindo-se ofendido com a questão, escreveu: "NENHUMA. QUAL É A SUA?" A maioria acha a prova de língua inglesa do vestibular difícil e assevera que suas aulas gramaticais são muito fracas. Um aluno referiu-se a suas aulas: "ingleis muito basico, má esplicação, ingleis básico (sic)". Somente uma minoria afirmou que a professora desenvolve a capacidade de interagir, interpretar e aprofundar leitura. Eles também não souberam opinar se a prova de inglês avalia adequadamente seus candidatos, pois a maioria deles nem conhece o exame ou simplesmente se recusou a responder. Apenas uma aluna disse que a prova avalia a "capacidade de conhecimento" do candidato.

Por causa da atitude hostil perante o questionário, somente três alunos opinaram sobre o poder do exame ser ou não um mecanismo eficiente de mudanças no ensino de inglês nas escolas de ensino médio. Uma delas relatou que "se o exame influenciasse as aulas eles teriam boas provas". Outra aluna disse que se isso ocorresse "os professores, a partir do $2^{\circ}$ ano do ensino médio, começariam a passar matéria do vestibular". Um último aluno disse que se isso ocorresse, "todos se interessariam mais..." Vemos que os alunos gostariam que a prova de língua inglesa balizasse suas aulas de inglês, pois para eles, isso lhes propiciaria uma chance de aprovação no vestibular e as aulas "ficariam mais interessantes."

Era visível e mútua a insatisfação na relação entre a professora e os alunos. Um sentimento de raiva tanto da professora quanto dos alunos imperava e fazia com que as aulas fossem bem pesadas, com agressões verbais recíprocas.

Neste cenário, o diretor-assistente, a professora e os alunos acham o exame de inglês do vestibular da UFPR bem difícil, assim como os sujeitos do cenário da escola rural. Aqui também é possível notar que o diretor-assistente e professora 
não acreditam que o exame de vestibular possa ser um instrumento balizador do ensino escola. Porém, alguns alunos, como na escola pública rural, afirmaram que se o exame de fato influenciasse a escola, o ensino seria melhor.

Os sujeitos das duas escolas públicas afirmam que o vestibular não avalia o que os alunos aprenderam na escola, uma vez que as escolas direcionam o ensino para a gramática, ao passo que o vestibular tende a avaliar a leitura. Os alunos também reclamam não possuírem o conhecimento necessário para prestarem o vestibular. Antagonicamente, o discurso ideológico dos professores, diretores, autores dos livros e coordenadora do SEED - de que os alunos de escola pública não almejam prosseguir estudos em nível superior - reproduz da mesma maneira genérica e abstrata com que o receberam, uma visão parcial e distorcida dos problemas que cercam a escola pública e, o que é pior, das possíveis soluções. Esse discurso de que é necessário preparar os alunos para o trabalho tem sua origem no Império, com a criação, em 1856, pela iniciativa privada, do Liceu de Artes e Ofícios, no Rio de Janeiro (Azevedo 1958, p. 82), seguido de outras escolas para profissionalizar filhos de ex-escravos e outros segmentos em desvantagem social. Até hoje, o ensino para o trabalho carrega um estigma de que o "trabalho manual" é "coisa" para os pobres.

Essa desesperança entre alunos, professor, diretor da escola e coordenadora de língua inglesa da SEED nos mostra um quadro de um grupo social totalmente neutralizado em um estado consolidado de submissão a uma elite que se sobrepuja através da supremacia do conhecimento. A sujeição a essa elite desencadeia um servilismo popular ativando posturas e maneiras de ser determinadas, como a visão derrotista de todos os sujeitos desses cenários de que não adianta preparar os alunos para o ensino superior porque eles são inferiores, menos preparados ou desinteressados.

Devido a esse cenário precário de educação, esses sujeitos não consideram o exame de inglês do vestibular da UFPR de alta relevância; ingressar na universidade não faz parte do universo de suas aspirações exeqüíveis. Por essa razão, o efeito retroativo não está presente nas escolas públicas investigadas.

\subsection{ESCOLA PARTICULAR - O COLÉGIO DB}

O colégio particular, doravante Colégio DB, atende as classes sociais A e B e oferece aos seus alunos o terceirão $0^{5}$ e o curso pré-vestibular, que são cursos totalmente dirigidos para aprovação nos vestibulares, principalmente da

5 No último ano do ensino médio, os alunos do $3^{\circ}$ ano passam a assistir às aulas com os alunos do curso pré-vestibular 
UFPR. Em média há doze turmas (de 150 alunos cada) de língua inglesa e duas de espanhol. Os alunos do terceirão são da classe A e B, ao passo que há uma maior heterogeneidade de classes sociais no curso pré-vestibular que também recebe alunos oriundos de escolas públicas e particulares da classe C. Os alunos do terceirão têm um bom conhecimento da língua inglesa, pois a língua vem sendo ensinada com intensidade desde o primeiro ano do ensino médio. Além disso, esses alunos já cursaram inglês em institutos de línguas e muitos já participaram de intercâmbio em países anglófonos. Já os alunos que entram somente para o curso pré-vestibular, que são oriundos de escolas públicas e particulares pequenas, não têm a mesma bagagem lingüística dos outros, e essa heterogeneidade obrigou a escola de formar dois tipos de aula de inglês: o inglês básico e o avançado. Para poder assistir às aulas do inglês avançado, o aluno é obrigado a fazer um teste de proficiência e atingir uma nota mínima estipulada pela escola.

\subsubsection{O diretor do Colégio DB}

Segundo o diretor (e professor de História) do colégio, sua instituição exige de seus professores um planejamento da programação anual totalmente balizado pelo programa oficial do vestibular da UFPR. Como o objetivo principal é preparar seus alunos para o vestibular da UFPR, nenhum documento oficial do MEC ou Estado é levado em conta no planejamento das disciplinas do ensino médio e pré-vestibular. Para o professor, o vestibular da UFPR é responsável pela existência do curso. Ao ser questionado se o vestibular da UFPR direcionava o ensino de sua instituição ele afirmou:

É balizador total. Tanto é que uma das nossas metas...(+) é a visão do DB enquanto escola e enquanto empresa é aprovar mais e melhor na Universidade Federal do Paraná. Esse é o nosso lema. Um dos nossos lemas: aprovar mais e melhor. Porque o aluno que vai fazer a Universidade Federal do Paraná e se ele for bem preparado para Federal, ele vai encarar praticamente qualquer outro vestibular, inclusive o Cefet com suas práticas excessivamente tecnológicas.

Para que seus professores possam desenvolver o trabalho voltado para o vestibular, a escola disponibiliza todo e qualquer tipo de recurso necessário, inclusive suportes multimídia. Todas as salas são equipadas com um aparelho de multimídia e um computador com acesso à Internet. Além desses recursos, os professores têm um profissional da área de informática para lhes dar suporte. 
Os profissionais também participam de cursos, reuniões, discussões, e outros tipos de eventos para instrumentalizá-los com a informação necessária sobre o vestibular. A maioria dos professores também escreve as apostilas das suas disciplinas, com apoio de uma editora da escola.

Como os cursos do Colégio DB são balizados pelo programa do exame vestibular da UFPR e outros vestibulares, foi perguntado ao diretor como sua escola conseguia informações necessárias sobre o exame para que eles conseguissem desenvolver seu trabalho. Ele disse que a instituição tem um bom relacionamento com a universidade. O colégio vê a Universidade Federal como "uma parceira no sentido de educação." A escola está sempre em contato com os responsáveis pelo vestibular e sempre que a universidade oferece reuniões ${ }^{6}$ com as escolas para falar do vestibular, eles estão presentes. Diferentemente dos professores das duas escolas públicas investigadas, o Colégio DB freqüentemente entra em contato com o núcleo de concursos da UFPR para se informar sobre o exame.

Além do contato permanente com a UFPR, nesse colégio são feitas análises dos vestibulares mais expressivos do país para que objetivos sejam traçados para seu ensino. O diretor descreve em detalhes como o planejamento é feito:

E nós sempre direcionamos a aprendizagem do DB pela caminhada da Federal. Então um exemplo: cinco anos atrás nós resolvemos fazer um estudo dos vestibulares da Federal. Embora a gente acompanhe todos os anos, nós resolvemos a prova da Federal, publicamos a prova da Federal resolvida, fazemos uma análise e tal. Mas há cinco anos atrás nós decidimos fazer mais... pegamos os vestibulares da Federal, da Unicamp, e da Fuvest e analisamos esses três vestibulares, principalmente da Federal; vestibulares de cinco anos anteriores. Fizemos toda uma planilha, todo um trabalho de análise dos conteúdos: os conteúdos que estão sendo pedidos, em cada disciplina, qual o enfoque dado a cada conteúdo, qual a habilidade que estava sendo cobrada, se era a habilidade de memorização, se era de interpretação, se era de análise, de comparação e em cima de todo esse estudo que foi feito da Federal, nós começamos a elaborar nossos projetos e planos de aula. Então nós fizemos o projeto de novas apostilas dentro daquilo que a Federal exige. Fizemos a distribuição

${ }^{6} \quad$ As reuniões da UFPR com as escolas aconteceram dois ou três anos consecutivos, uma vez no ano. 
de carga horária, nossa grade curricular, isso pro ensino médio $-1^{a}$, $2^{a}$, $3^{a}$ séries e cursinho - então todos nós começamos a nos balizar pela Federal. Quer dizer, se um determinado conteúdo suponhamos, geometria espacial, na Federal está sendo pouco solicitado este é um conteúdo que nós não precisamos privilegiar tanto aqui...não que não vá ser dado. Já supomos, na Matemática, álgebra.....chegamos à conclusão de que 70\% da prova da Federal era álgebra em Matemática. Evidente que a nossa apostila vai ser direcionada pra isso... a maior quantidade de álgebra. E assim sucessivamente. Então, por exemplo, na História, já que sou professor de história, cai uma só questão de história antiga. Então nós não vamos priorizar história antiga. Nós vamos dar aula de uma maneira mais rápida para poder atender as necessidades dos alunos. E estamos sempre acompanhando o que a Federal pretende fazer. Então tem uma reunião qualquer da Federal sobre discussão sobre processos seletivos, nós nos encontraremos lá presentes. Discutindo, acompanhando, o que está acontecendo. Não nos metemos no processo do vestibular da Federal, ela é autônoma o suficiente que não deve aceitar pressões. Mas nós acreditamos que o vestibular da Federal é um bom vestibular, com um conteúdo bom, e nos balizamos por aquilo que nossos alunos precisam.

Portanto, a partir da descrição do diretor de como a escola desenvolve seu planejamento anual de ensino do $1^{\circ}, 2^{\circ}, 3^{\circ}$ anos do ensino médio e curso pré-vestibular, podemos observar que há um forte efeito retroativo do vestibular no ensino que o precede. O efeito é tão intenso que o curso, como um todo, gira em função do exame, desde a ementa das disciplinas, confecção da grade escolar, o desenvolvimento do material didático, conteúdo ensinado, seqüência dos conteúdos ensinados e mudanças de avaliações, na maioria simulados do próprio exame. Um efeito negativo a considerar é que o colégio, ao direcionar seu planejamento totalmente balizado pelo programa do vestibular da UFPR, provoca um estreitamento de currículo e conteúdos importantes podem ser desconsiderados em virtude do programa do exame. Um outro efeito negativo pode ocorrer uma vez que não há uma preocupação consciente em analisar e discutir as concepções de linguagem, de língua e de avaliação por de trás do exame, fica difícil estabelecer uma metodologia adequada para trabalhar tais conteúdos. Mas, ao contrário das escolas públicas, os professores sabem exatamente o que vai ser ensinado em sala. Há, sem dúvida, um objetivo específico e bem delimitado que pode ser encarado como um efeito positivo. 
O diretor afirma que o vestibular da UFPR pode e deve seu um mecanismo eficiente de mudanças no ensino médio, tanto que seu curso é um exemplo vivo desse efeito. Ao defender o exame como mecanismo de mudanças, o professor disse:

Eu quando dou palestras por ai, eu discuto a educação com colegas e escolas...quando vem essa cantilena, na minha opinião ingênua ou boba, dizendo que o mal da educação é o vestibular eu discordo totalmente. Eu acho que queiramos ou não o vestibular direciona sim: o ensino médio e fundamental. Com algumas pessoas com as quais eu discuto, eu digo assim: 'Você tem filhos? - Tem. Já fez vestibular? Vai fazer? Está próximo? - Ah já fez.. - Está próximo... Pois é. Você botou seu filho no cursinho?' Normalmente sim. Ou então eu pergunto a você se botou em alguma escola que tem terceirão. '- Ah, é lógico, né?' Entre botar no cursinho ou deixar no Bom Jesus, Santa Maria, ou não sei onde, mas que tem o terceiro ano voltado para o vestibular, é cursinho igual, só que é um cursinho com 40, 50 alunos. Nós trabalhamos com um número muito maior: é igual. Mas dai eu pergunto: 'Por que você não põe numa escola que não tem nenhuma preocupação com o vestibular?' Primeiro que seu filho não quer e segundo você sabe que a realidade não é essa. Então vamos botar o pé no chão.

Na fala do diretor, podemos observar a importância que ele dá ao vestibular e, também, perceber sua preocupação em preparar jovens para tal exame. Segundo o professor, como o exame de vestibular da UFPR é um bom instrumento de avaliação, balizar o curso do ensino médio por ele é visto como algo positivo e não um fator limitador que causa estreitamento de currículo ou ensino de "macetes". No entanto, o diretor desconhece que a prova de inglês de vestibular da UFPR tem alguns fatores limitadores e não propicia ao aluno/ candidato a trabalhar a leitura em um nível de maior complexidade: questões com predominância argumentativa, por exemplo (ver análise do exame no item 4.1.2). Esse desconhecimento pode levar o professor a trabalhar o texto somente em um nível de reconstituição de informação pontual linear que é simples e não exige grandes habilidades do aluno. Ele também fala sobre a importância de se conquistar um título universitário no Brasil para que o aluno consiga se inserir no mercado de trabalho competitivo e no qual funções mais lucrativas requerem uma capacitação de ensino superior. Segundo o diretor, o ingresso na universidade propiciará uma mudança grande na vida de um aluno. Ele afirma: 
A realidade é: qual é a oportunidade que o jovem tem neste pais? De se inserir num mercado de trabalho, de buscar uma profissão. Se não, se ele for de classe média pra cima, ou mesmo de classe média baixa, entrar numa universidade. Fora isso não tem campo. O que que ele vaifazer com o ensino fundamental e o ensino médio? NADA. Mão-de-obra, ZERO. E não é o sonho que você tem pros seus filhos. Nem que ele tem pra ele mesmo enquanto aluno. Então o vestibular passa a ser pra ele ao entrar na universidade..... passa a ser pra ele um grande fator de transformação de sua própria existência. Pra chegar lá ele tem que passar pro vestibular. Ai olhando agora do contrário: de cima pra baixo. A gente fez o caminho de baixo pra cima. Qual é a família que quer que o filho tenha sucesso na vida, que seja bem isso, ou aquilo. Caso contrário é pura filosofia e eu sou formado em Filosofia. Mas a pura filosofia de botequim. Ficar discutindo que o mal da educação é o vestibular quando na prática você mesmo vai botar o seu filho pra fazer o vestibular.

O diretor também acha que, se o exame for de boa qualidade, ele tenderá a provocar um efeito positivo, e assim as aulas tendem a ser boas, ao passo que as provas de baixa qualidade vão provocar aulas de qualidade baixa. Essa é uma visão determinista que tem que ser vista com cautela. Nem sempre um bom exame provocará um efeito positivo e o inverso também é verdadeiro, ou seja, nem sempre um mau exame provocará um efeito negativo. Se o professor for capacitado, ele dará boas aulas independentemente do exame ser bom ou não, e preparará bem seus alunos, mesmo que seja para fazer uma prova fraca. Scaramucci (1998, 1999b, 1999c, 2001/02) mostra como o determinismo de exame bom versus ruim não faz mais parte das crenças dos pesquisadores ao afirmar que "um mesmo exame pode ter efeitos de intensidades diferentes em contextos diversos, pois há forças diferentes agindo como as diferentes formações de professores, e que o efeito retroativo é dependente das crenças do professor a respeito do ensino". A pesquisadora (1999, p. 119) nos alerta para o fato de que uma boa formação do professor é primordial para que um exame possa ser, potencialmente, um agente positivo de mudanças. Porém, o que ocorre de fato é que 'o professor [muitas vezes] não se considera parte desse processo, um agente de mudanças, mas apenas um aplicador de propostas [PCEM, PCN+, programas de vestibulares, etc]'. Esse quadro desfavorável surge por causa das condições precárias das quais o professor tem que enfrentar, tais como afirma Scaramucci (op. cit., p. 119) má remuneração, classes superlotadas, alunos desmotivados e indisciplinados, e a fraca formação universitária 
desses professores. Scaramucci (2001/2002, p. 102) assevera que "por mais paradoxal que possa parecer, portanto, uma mesma avaliação ou exame poderia ter, ao mesmo tempo, efeitos positivos e negativos (ver itens 2.4.1.1 e 2.4.1.2), que seriam percebidos de forma diferenciada por professores e alunos, dependendo de seus traços de personalidade e cultura de ensino/aprender/avaliar/ser avaliado. Também a conclusão a que Alderson e Hamp-Lyons (1996) chegaram e que vem contribuir com o nosso argumento é que "testes provocarão tipos e intensidade diferentes de efeito retroativo em alguns professores e aprendizes do que em outros". Scaramucci (1999, 2001, 2001/2002, 2002) confirmou a hipótese de Alderson e Hamp-Lyons com os resultados de uma pesquisa desenvolvida no contexto de vestibular brasileiro. Portanto, não podemos concordar com o diretor quando ele afirma que necessariamente um teste bom incentivará boas aulas.

Mesmo achando que somente testes bons desencadeia boas aulas, a obrigação do ensino médio, segundo ele, é atender as necessidades dos alunos e fazer o possível para que eles possam ser aprovados nos vestibulares, seja com exames de boa qualidade, seja com exames de baixa qualidade. Ele explica:

Agora olhando de cima pra baixo, o que nós vemos é que essa universidade é a mais procurada. Então pegamos a Federal com seus 70 mil candidatos. Queremos ou não todo mundo quer passar na Federal. Só não vai querer aquele que não tem o curso na Federal. Ai se esse individuo quer a universidade e ela está cobrando isso, essa cobrança da forma como ela cobra, das habilidades que ela forma, ela cobra, evidentemente vai direcionar quem está tentando chegar lá. Então quando o vestibular da Federal era a "decoreba" a prática do ensino médio era "decoreba". Eu dou aula há 37 anos. E no inicio era "decoreba" mesmo. Fazia decorar aquela baboserada de nomes de presidentes da república que não serve pra nada. Aquela baboserada de nomes de imperadores romanos que só serve pra botar no lixo. Porque o vestibular ia cobrar isso.

O diretor também critica as universidades que fazem críticas aos cursos pré-vestibulares. Ele diz que quando as universidades afirmam que os cursos pré-vestibulares oferecem um ensino massificado, voltado somente para informação e não para a formação de um aluno, tais instituições não conseguem ver que quem dita a qualidade de ensino que o precede é o próprio exame de vestibular que eles elaboram. Portanto, segundo o diretor, se eles desenvolvem um exame de baixa qualidade, os cursos pré-vestibulares têm que se adequar 
àquele tipo de exame. O diretor culpa os próprios elaboradores de vestibulares de baixa qualidade pelas aulas "decorebas". Ele assevera:

O próprio Cefet começou a mudar seu vestibular tornando-o um pouquinho mais crítico, mais analítico agora. Porque eu me recordo de provas do Cefet que eu cansei de criticar em público...abertamente aqui no D B, provas de histórias horriveis. E uma delas, talvez uns dez anos atrás perguntava assim: qual o Papa que coroou o imperador Carlos Magno no ano 800? Letra A-João terceiro; letra B - Paulo não sei o que; Letra C-Paulo terceiro; Cinco nomes de Papa pra perguntar algo muito significante, que foi quem colocou a coroa na cabeça do Carlos Magno. Ai pra que serve isso? Mas um aluno que vai fazer Cefet, ele vai querer de mim ou de qualquer outro professor de história que esteja dando aula pra ele, que diga exatamente aquilo que o Cefet vai cobrar. Então NÃO adianta eu ficar falando do Carlos Magno e a importância dele na história, sobre o que aconteceu durante seu governo, quando o aluno quer apenas o nome do Papa que corou o Carlos Magno. Quer dizer: é a própria instituição de ensino superior que tá direcionando pro ensino médio o que ele tem que fazer. E ai o próprio professor da universidade aproveitava e fazia crítica dos cursinhos. Porque o cursinho só ensina "decoreba", mas são vocês que elaboram questões de "decoreba". Ai quando a gente começa a entrar nessa discussão, eles não querem mais brincar de discutir.

Esta última afirmação do diretor parece ser bastante determinista, pois, como já havia dito Scaramucci (2002b; p. 101-102) qualquer avaliação, independentemente de sua qualidade e natureza, pode provocar um efeito positivo (ver item 2.4.1.1) na medida em que pode levar os professores a preparar melhor suas aulas, os alunos a estudar mais, a fazer lição de casa, os professores a procurar capacitação contínua etc., ou negativo (ver item 2.4.1.2) - estreitamento do currículo, ansiedade do aluno, ensino de macetes etc.. Portanto, um exame de má qualidade não necessariamente obrigaria uma escola a adaptarse a ele. Se o exame for bem conhecido e a filosofia que embasa tal exame for entendida, um professor poderá oferecer um bom curso no qual o aluno poderá se preparar para exames de boa e má qualidade ao mesmo tempo. Como afirma Scaramucci (2001/2002, p. 102):

'reconhecer esse outro tipo de efeito retroativo [direto que está relacionado à "qualidade" da avaliação ou exame e as suas características], por um lado, significa considerar a qualidade do exame como 
um dos fatores importantes na determinação de um efeito retroativo benéfico e, embora não suficiente, uma condição necessária, que deveria ser buscada a todo custo por responsáveis por exames e avaliações, e educadores em geral'.

Pode-se observar a opinião forte do diretor sobre a importância do vestibular na vida de um aluno e como uma boa prova, como a da Federal, pode suscitar um efeito retroativo benéfico se a instituição souber analisar, entender e utilizar o exame adequadamente. Porém, notamos que o diretor pensa somente em relação aos conteúdos a serem ensinados e não como ensiná-los - logo, o exame pode exercer um efeito positivo em relação aos conteúdos a serem ensinados/aprendidos e negativo em relação à mudança de metodologia. Seus professores e alunos se preocupam e muito com a preparação para o vestibular, pois ser aprovado no vestibular significa um momento decisivo em suas vidas.

Mais especificamente sobre a prova de língua inglesa do exame, o diretor pensa que as provas não são difíceis e que não têm fugido da proposta da Federal, ou seja, daquilo que o aluno vai precisar na universidade, que é a interpretação de textos. Segundo o professor, muitos alunos gabaritam a prova, diferentemente das provas de redação e das de exatas que oferecem um nível de dificuldade muito maior. Por estar dentro da proposta de interpretação de textos, ele pensa que a prova avalia adequadamente seus candidatos. As altas notas nas provas de língua inglesa são atribuídas pelo diretor a alguns fatores: primeiramente as provas não apresentam um grau de dificuldade muito grande. Em um segundo momento, muitos alunos que freqüentam o Colégio DB ou já estudaram a língua em institutos de línguas estrangeiras, ou já fizeram intercâmbio no exterior, trazem um conhecimento da língua muito bom para a escola. Como o colégio já conhece o perfil dos alunos, eles dividem o ensino da língua inglesa em dois níveis: básico e avançado. Os alunos que já possuem um conhecimento da língua inglesa bom, fazem uma avaliação e, se forem bem, poderão assistir às aulas do curso avançado, que têm foco em interpretação de textos, ensino de vocabulário mais extenso e gramática avançada. Os alunos que não conseguem uma boa pontuação na prova de colocação, são direcionados ou para aulas de espanhol, ou para as de inglês básico.

O professor do Colégio DB acredita que o exame de vestibular da UFPR é um bom instrumento de avaliação e que ele influencia totalmente sua escola. Ele afirma que está sempre disposto a mudar a estrutura da escola para se adequar às mudanças que o exame impõe. O professor afirma que "nós estamos sempre atentos: mudou a Federal, nós estamos mudando em seguida." 
Este comentário nos mostra o quão forte é o efeito retroativo do vestibular nessa escola, na percepção do seu diretor.

\subsubsection{As percepções do professor do Colégio DB}

Nos últimos anos, o número de alunos/candidatos que opta pela prova de espanhol no vestibular da UFPR vem aumentando significativamente. O professor se queixa:

O grande problema que nós enfrentamos com nossa disciplina é a questão da opção da língua estrangeira pelo espanhol. Então isso representa para o aluno uma porta dos fundos aberta. Eu não concordo. Então eles estão conscientes, mas aqui o problema é que nós trabalhamos com uma faixa etária onde o esforço é sempre uma barreira. Ai tem que fazer força, tem que se dedicar...deixa pra depois. Muitos ainda não têm aquela visão de futuro. O mais distante que eles vislumbram é o final de semana...com quem eu vou sair, com quem eu vou ficar. Agora tem aqueles que são conscientes e são os que assistem às aulas...

O professor do Colégio DB conhece bem o perfil de seus alunos, que são das classes A, B e C. O professor alerta que são poucos os que têm consciência da importância em saber a língua inglesa para futuros desempenhos. Muitos alunos estão optando em fazer a prova de língua espanhola por acharem que irão obter uma melhor pontuação, apesar da experiência em vestibulares não confirmar isso, segundo o professor.

O professor vê o vestibular "como o primeiro grande obstáculo na vida de seus alunos. É como se fosse como uma iniciação a uma vida adulta e acadêmica... que é realmente assumir as responsabilidades deles e ele sabe que tudo depende dele". Os professores do Colégio DB não somente trabalham os conteúdos que os alunos necessitam dominar, mas também a questão do amadurecimento, da responsabilidade que eles têm que assumir para poderem vencer o obstáculo do vestibular. Isso é trabalhar para a cidadania, como reza a LDBEN. O professor ressalta:

Então nós trabalhamos muito em cima disso. Essa coisa do psicológico, do emocional para eles sentirem que é um momento de iniciação na vida dele. Que passando por esse obstáculo, vencendo esse obstáculo ele vai ter outros que vão ter que ser ultrapassados. A pri- 
meira experiência é muito importante. Se a primeira experiência é boa, provavelmente as outras também vão ser.

A visão que esses profissionais têm do vestibular e de si próprios é que eles são "os super-heróis que vão ajudá-los [os alunos] a transpor essa barreira imensa que é o vestibular". Para o professor de Inglês o vestibular também é seu "ganha-pão", e sem esse exame ele não teria emprego.

Para a turma avançada do Inglês, além de serem usadas apostilas escritas pelo próprio professor, existe uma apostila complementar com textos e exercícios de vocabulário com maior grau de dificuldade (Anexo C.6) do que a apostila regular.

As apostilas são desenvolvidas com um só objetivo: passar no vestibular da UFPR. Para isso, o professor dividiu seu material em duas "frentes": uma que é o ensino da gramática e a outra que é a prática de compreensão de textos. A gramática ensinada em uma aula é aplicada ao texto na aula seguinte. Ele acredita que, através da interpretação de textos, o aluno tem que mostrar sua habilidade em funcionar dentro da língua, e que assim a gramática está sendo avaliada de maneira contextualizada. É por esse motivo que o ensino de gramática pela gramática não tem mais espaço apesar de alguns colegas reivindicarem a volta da "velha gramática".

Interessante salientar é que apesar do discurso do professor, suas aulas são bastante centradas em gramática, e muitas vezes os textos servem de pretexto para o ensino de gramática (ver próxima seção). Com relação à interpretação, ele somente suscita as respostas corretas de exames anteriores. Não há um aprofundamento dos tipos de questões e como se posicionar diante delas. O professor relatou como os objetivos de suas apostilas e aulas foram traçados:

Nós fizemos um estudo bastante grande aqui no D B uns dois, três anos atrás. Nós pegamos os cinco últimos vestibulares. Todos os professores aqui do cursinho... nós passamos as férias todas fazendo uma análise do conteúdo, das provas, o grau de dificuldade das provas para que nós pudéssemos estabelecer o que colocar na apostila. Essa, na verdade foi a primeira etapa. Foi o primeiro passo para a criação dessa última apostila. As apostilas são renováveis a cada três anos. O ano que vem a gente vai ter que dar uma mexidinha nela. Nós fizemos essa análise. Então dentro dessa análise eu consegui quantificar, qualificar todos os pontos da gramática. Os mais importantes. Então eu sei que com modal verbs eu preciso duas aulas. Para eu disponibilizar uma aula a mais para modal verbs, eu 
vou ter que tirar alguma coisa de lá de trás. Então eu tiro uma aula de plural form. Não significa nada. Vai tá na apostila. Eu digo para eles: - leiam em casa. O material 'é aqui. Você lendo, ou eu falando é a mesma coisa. Vai ser só mais engraçadinho comigo. Você consegue aprender sozinho. Então nós fizemos esse estudo e isso nos deu uma visão muito clara do que é hoje o exame do vestibular da Federal e logicamente, a partir daí nós estabelecemos as estratégias de criação do material ao mesmo tempo você vai criando as tuas estratégias dentro do curso. Estratégias didáticas. Sempre a coisa vem a partir do vestibular da Federal.

O modo pelo qual o professor analisou os exames de vestibular da UFPR e elaborou sua grade, podemos notar uma forte tendência ao ensino da gramática. Pela sua fala, parece que o ensino de leitura ficou em segundo plano.

O professor tem a total liberdade de estabelecer seus objetivos e de desenvolver seu próprio material. A escola tem o seguinte lema para o professor: "Se você está aqui, se você chegou até aqui é porque você é muito bom no que faz, então faça o que você sabe fazer de bom ... o melhor".

Para confeccionar seu material, o professor está sempre em contato com a UFPR. Ele lamenta que as reuniões sobre a prova de línguas estrangeiras do vestibular com o Departamento de Línguas Estrangeiras Modernas da UFPR não são mais oferecidas, e disse que tais reuniões eram um ótimo veículo de comunicação entre a universidade e a comunidade. Era um espaço no qual se podia discutir e expressar as avaliações sobre as provas. Existe também comunicação sobre os vestibulares entre os professores de outros cursinhos que, geralmente, são amigos. Prática que não acontece entre os professores das escolas públicas.

O professor considera a prova de língua inglesa do vestibular da Federal uma prova difícil e que não condiz com o ensino de língua estrangeira no país. Ele assegura que "a prova é difícil considerando a preparação que os alunos têm desde a quinta série do ensino fundamental", e ele vê "que o vestibular não condiz com a realidade do ensino da língua inglesa no país ou que o ensino de língua inglesa do nosso país não condiz com o vestibular".

Mesmo conhecendo as defasagens que alguns alunos trazem para escola em termos de conhecimento sistêmico da língua inglesa, o professor tem como objetivo desenvolver a gramática, a capacidade de interpretar, aprofundar a leitura e estratégias de leitura. Independentemente do tipo de preparação para o vestibular, o professor advoga que os textos da prova de língua inglesa deveriam 
ser "mais práticos", "mais dentro da realidade que eles vão ter que enfrentar na próxima etapa". Segundo o professor, "a Federal fica muito em cima de "textinhos' quando ela poderia partir para um manual de instruções, uma coisa um pouco mais prática. Alguma coisa mais dentro da realidade do aluno". Por esse motivo ele acha que o exame de vestibular não contempla os conteúdos e capacidades necessárias para quem pretende usar o inglês na universidade. O professor ressalta que "na universidade ele vai ter que trabalhar com uma linguagem mais técnica, uma linguagem mais 'elitista' dentro dos materiais que eles vão ter que pesquisar". Portanto, o vestibular não garante ao aluno a funcionalidade nos anos que ele vai ter que enfrentar na universidade.

Discordo com a afirmação do professor quando ele chama todos os textos de 'textinhos'. Na verdade, os textos de alguns exames foram muito bem escolhidos tais como No play? No Was! (2000), A Century of Mathematics (2000), Why hurricanes hit in summer, early fal (2000), Is Global Warming Harmful to Health? (2002), Suspected Thief Drowns (2003), Male contraceptive, 100\% effective (2004), Battle over Texas sex-ed Textbooks (2005) (Anexo C). O que faltou nesses exames foi a elaboração de questões que chamassem a atenção dos alunos/candidatos para aspectos tais como, apreensão de julgamento de valor, a reconstrução da cadeia argumentativa do texto, dentre outros.

O discurso do professor se torna inconsistente uma vez que ele escolheu tomar o exame de vestibular da UFPR como instrumento direcionador de suas aulas. Ora ele enaltece o exame afirmando que é razão da existência do curso e de seu emprego, ora o critica asseverando que é muito difícil e longe da realidade das escolas brasileiras.

Segundo o professor, cada curso teria que ter uma prova específica de inglês, pois cada curso possui textos científicos próprios de suas áreas: seria impossível, por exemplo, termos uma prova com um tema específico de física e candidatos de letras ou direito responderem ou vice-versa.

Ao ser questionado se o vestibular pode ser um mecanismo eficiente de mudanças no ensino de inglês nas escolas de ensino médio, ele postula que o programa de vestibular deveria ser parâmetro de ensino para todas as escolas do país: particulares e públicas. Ele vê o vestibular como um instrumento muito importante: 'it's like a shaping instrument' (é como se fosse um instrumento que molda), filosofia compartilhada pela instituição: "o Colégio DB tem como missão aprovar mais e melhor na Universidade Federal do Paraná." Ele fundamenta sua opinião ao referir-se à instituição, 
É ele quem vai dar o direcionamento da preparação. Se nós acreditamos que o vestibular é uma instituição que vai estar aqui e que vai continuar, não vemos de outra forma hoje para uma seleção para a Universidade Federal. Pra nós do DB, tudo mudou quando nós decidimos preparar nossos materiais, não só aqui no cursinho, mas no ensino médio também - primeiro e segundo anos visando para preparação para a Universidade Federal do Paraná. Todas as disciplinas têm esse norte: Federal do Paraná. Por quê? Porque o objetivo, a missão do DB hoje, no ensino médio e cursinho, é aprovar mais e melhor na Universidade Federal do Paraná. Esse é o nosso objetivo, essa é a nossa missão. Nós chegamos a essa conclusão há quatro anos atrás. OD B tem como missão aprovar mais e melhor na Universidade Federal do Paraná. Logicamente, como nós dependemos de uma preparação anterior, vamos assim até o inicio do ensino médio, esse norte também deve ser seguido por esse níveis: primeiro e segundo anos. Então a coisa funciona assim. Sem dúvida alguma. Deveria ser preparar os alunos em cima disso. Por isso da importância do vestibular.

Apesar de defender o vestibular como um mecanismo eficiente de mudanças para o ensino médio, o professor ressalva que ele tem uma preocupação pessoal de ensinar a língua não somente para o vestibular, mas para a vida acadêmica e profissional, que para ele, estão inter-relacionadas. Ele é contra o professor que se concentra única e exclusivamente no exame, pois isso pode criar uma expectativa negativa no aluno. Ele assegura que "ele é um professor, não um educador, but I'm not a coach (não sou um treinador)". O professor, aqui, apresenta um discurso bastante paradoxal. Se ele não se preocupa somente com o vestibular, mas também com a vida acadêmica e profissional de seus alunos, então ele está assumindo o papel de um verdadeiro educador: educar para a cidadania. Porém, ele nega essa condição - "não sou educador" - e diz que também não é um treinador. Na verdade, se o professor tiver bem claro o que ensinar e como ensinar, a língua inglesa serviria como um instrumento pelo qual valores e conhecimentos gerais da vida são abordados e discutidos em sala de aula. Um bom professor de inglês pode e deve ensinar a língua através de temas e situações nas quais ele trabalhe conceitos, concepções, valores e conhecimentos gerais.

Como ele tinha dificuldade de criar atividades motivadoras de compreensão de textos, ele teve a ideia de começar a também trabalhar textos de comerciais de televisão, pois "tais atividades trabalham não somente a parte textual, mas também o visual, o som, mesmo a situação, normalmente são situações 
engraçadas, divertidas inusitadas, coisas que marcam, que ficam impressas na memória....e sempre vendo o texto (mesmo que seja um texto oral)". Ele afirma que foi um trabalho "maluco": para cada comercial utilizado em aula, vinte eram jogados fora; em média 30 a 40 comerciais eram baixados da Internet para se achar dois ou três que servissem. Trabalho árduo que rendeu bons frutos. No aspecto de recursos materiais a instituição disponibiliza, entre outros, qualquer material ou equipamento que o professor necessite para melhorar sua sala de aula.

Mesmo tendo a opinião de que o vestibular da UFPR não reflete a realidade brasileira do ensino de língua inglesa, ele acha que o exame é bem elaborado porque para ele, somente uma minoria de alunos tem um bom conhecimento da língua e são capazes de desenvolver uma compreensão de texto adequada para serem bem sucedidos no vestibular, ou seja, o exame somente seleciona os melhores.

Mas, não seria esse o objetivo dos elaboradores da universidade? Selecionar os melhores? Então, será que não está na hora das escolas públicas e particulares começarem acordar para o problema e desenvolverem projetos de ensino de LE adequados?

\subsubsection{As aulas do professor do Colégio DB}

Foram observadas, durante oito semanas, 10 aulas do curso regular cujos alunos têm pouco conhecimento da língua inglesa; e 4 aulas do curso inglês avançado cujos alunos têm pelo menos nível intermediário. O professor do Colégio DB tem à sua disposição um data show, um computador com Internet, lousa branca, e qualquer tipo de equipamento ou material que requisitar. O uso do data show impressiona pelos recursos que o professor pode utilizar, como incluir palavras ou orações, excluí-las, colocá-las em evidência, responder às perguntas com um clique; tudo isso acompanhado de sonoplastia, desenhos e figuras que entusiasmam.

Apesar de o professor ter dito que a gramática ensinada estava a serviço dos textos, ele trabalhava os pontos gramaticais aos moldes tradicionais, explicando cada detalhe do ponto, e para logo a seguir trabalhar itens isolados. Quase todas as explicações eram feitas com auxílio do data-show.

Exemplo de uma aula do curso regular:

1. O professor anunciou que eles iriam trabalhar tempos verbais. Ele trabalha o Simple Past. 
2. Ele mostrou um slide com uma historia de quadrinhos da página 5 da apostila (Anexo F.1).

3. A partir do slide, ele perguntou aos alunos o que aconteceu. Ele estabeleceu a lista de orações no passado aos poucos, a partir dos alunos:

I woke up this morning.

I got dressed.

I grabbed my wallet.

I had breakfast.

I fed my dog.

I rode my bike to work.

I was at the factory all day.

The bell rang.
I clocked out, drove home.

I changed my clothes.

I borrowed the keys from grandpa.

I know I had it when I left home.

I took the T-bird.

I parked it on Main St.

I ran to meet you cause I was late

I crossed the street.

Then, I got hit by a truck.

4. Ele explicou a diferença entre verbos regulares e irregulares. Também explicou como se forma o passado simples regular e disse, enfaticamente, que os irregulares tinham que ser memorizados. O professor pediu-lhes para abrirem a apostila nas páginas 6, 7, e 8 (Anexo C.2) - que apresentavam uma lista gigantesca de verbos irregulares. Ele falou sobre maneiras de memorizar os verbos - repetindo muitas vezes, agrupando por sons semelhantes etc.

5. A seguir, ele explicou como se fazia a negativa e interrogativa dos verbos no passado simples, mostrando exemplos no data-show.

6. Logo depois, ele mostrou em um slide uma linha do tempo e explicou quando usar o passado simples:

- $\quad$ É usado antes do momento da fala. (Dan played soccer last week)

- É usado para expressar um fato passado, mas que teve uma certa duração (é pretérito imperfeito - I hated math, but loved history.)

- É usado para expressar um acontecimento habitual ou freqüente no passado (pretérito imperfeito - When I was a teenager, I smoked a lot.)

7. O professor corrigiu os exercícios de Simple Past das páginas 8 e 9 (Anexo C.1, C.2 e C.3) de gramática - itens isolados e tradução. E logo a seguir, explicou o Present Perfect da mesma maneira que o Simple Past foi explicado. 
Como podemos notar, em duas aulas, o professor trabalhou o item gramatical - Simple Past - como no tempo do Método Gramática-Tradução. Após as explicações, os exemplos eram dados e traduzidos. Nessa mesma aula, ele também explicou o Present Perfect e o Past Progressive, fez alguns exercícios da apostila, e pediu para que o restante fosse feito em casa.

Se um aluno já sabe a língua, então a aula do professor é uma grande e rápida revisão gramatical. Agora, se um aluno nunca viu aquela matéria, não será em duas aulas que ele aprenderá tantos tempos verbais de uma vez só.

$\mathrm{Na}$ aula seguinte, o professor corrigiu os exercícios que haviam sido pedidos na aula anterior e começou a trabalhar a leitura.

A segunda parte da apostila é dedicada ao ensino da leitura através de algumas concepções da abordagem instrumental. Por toda apostila conceitos como skimming, scanning, sintagma nominal, sintagma verbal, cognatos, falso cognatos e outros conceitos são explicados e exercitados. Na introdução dessa parte (Anexo C.4) o professor justifica a abordagem instrumental dizendo:

As universidades e faculdades do maior projeto nacional vêm abandonando as questões convencionais de gramática e aumentando o número de testes de compreensão de textos em língua inglesa. Isso é reflexo de um programa internacional, envolvendo as universidades brasileiras que recebe o nome de inglês instrumental ou English for Specific Purposes (ESP) - Inglês para fins especificos. O objetivo é possibilitar ao acadêmico entender o máximo de informações no minimo tempo, sem necessitar traduzir literalmente os textos. Ele deve aprender retirar do texto apenas as informações relevantes. Para você poder atingir esse objetivo, deve aplicar certas técnicas ou estratégias simples, mas eficientes, além de ousar bastante. Se já possui algum conhecimento da língua, melhor; se não, verá que vai evoluir bastante.

Quando o professor afirma que 'ele [o aluno] deve aprender retirar do texto apenas as informações relevantes', ele está nos mostrando sua visão de leitura tradicional de 'retirar' informações 'cristalizadas' do texto. Interessante ressaltar é que ele, na verdade, não abandonou o ensino de gramática aos moldes convencionais. Ele apenas passou a dedicar uma parte de suas aulas para o desenvolvimento da leitura. Para atingir tal objetivo, o professor escolheu utilizar conceitos desenvolvidos a partir do Projeto Instrumental da PUC-SP, no final dos anos 70, começo dos 80. Porém, desde os anos 70, as concepções de leitura, e, conseqüentemente, o ensino da leitura têm evoluído bastante. $\mathrm{O}$ professor parece ter ficado preso no modelo descendente ou psicolingüístico 
da língua (modelo utilizado no início do Projeto Instrumental) negligenciando uma visão mais atualizada de leitura: o modelo interativo. Se tivesse inserido suas aulas a partir do modelo interativo (ver item 2.2), ele saberia mostrar aos alunos como o sistema lingüístico, juntamente com conhecimento prévio do assunto e de mundo estão a serviço da construção de significado do texto.

O professor não reviu suas concepções de linguagem e de leitura, apenas adicionou algumas 'receitas' ou 'modismos' do ensino instrumental e de uma visão de leitura descendente dos anos 70 e 80.

Sua prática de ensino de leitura mostra tal tendência. Nas páginas 1 e 4 da segunda parte da apostila (Anexos C. 4, e C. 5) vemos suas instruções para o uso de técnicas do Instrumental. Na página 4 (Anexos C. 5) ao abordar a técnica (como ele a denomina) de scanning, notamos, em seu discurso, alguns equívocos. Ele afirma:

O INGLES INSTRUMENTAL - a abordagem mais moderna e cada vez mais aplicada em vestibulares - considera que não é preciso extrair tudo de um texto, mas as informações importantes. Para isso, usa-se a técnica do scanning - ou rastreamento: à medida que o leitor vai lendo o texto, pode ir marcando o que lhe parece importante - nome, lugares, numerais, palavras repetidas (palavra-chave), siglas, logotipo, marcas, figuras, desenhos, fotos. (p. 04 -Anexo C.5)

Em sua fala, notamos que ele chama o instrumental de "a abordagem mais moderna”, o que não é verdade. O Inglês Instrumental passou a ser uma metodologia de ensino de leitura e não é moderna - surgiu no Brasil nos anos 70. Um outro equívoco é dizer que "o inglês instrumental é cada vez mais aplicado nos vestibulares". Na verdade, os leitores/candidatos podem fazer uso dessas, e outras estratégias advogadas pela cultura do ensino instrumental (skimming, scanning, criar hipóteses sobre o texto) para construir o sentido do texto, mas não 'aplicarem o Instrumental' em um exame, pois os exames têm por objetivo avaliar a proficiência de leitura e não os atributos defendidos pela metodologia do Instrumental, ou seja, o construto do exame é a leitura e não a metodologia Instrumental. Os comentários do professor revelam que seu conhecimento de concepções de leitura, de linguagem, de leitura e das teorias que embasam o inglês instrumental é superficial.

Ao apresentar os textos - de vestibulares anteriores, de revistas e jornais, etc - muitas vezes ele pede para os alunos traduzirem ou o título ou partes do texto para depois perguntar à turma a alternativa correta, utilizando cores e sons para questões certas e falsas: aulas 'super pop show'. O professor recomenda as seguintes estratégias de leitura (Anexo C.6. p.3): 


\section{O aluno deve ter um plano de ação definido para prova de inglês da UFPR}

Espera-se que a prova de inglês do vestibular 2005 da UFPR, como a dos anos anteriores, seja de compreensão e interpretação de textos.

É muito importante que o aluno tenha um plano de ação bem definido para resolver essas questões. Um bom método de resolução não somente maximiza as chances de sucesso do candidato, mas também o tranqüiliza.

Aqui vão algumas dicas que poderão ser adaptadas ao nível de compreensão de cada candidato:

1. Analise o layout do texto e identifique a sua tipologia.

2. Procure interpretar o título do texto e também qualquer figura, se houver.

3. Verifique se há vocabulário. Se as palavras contidas no vocabulário forem desconhecidas, quando fizer a $1^{\mathrm{a}}$ leitura do texto, destaque-as.

4. Faça a $1^{\text {a }}$ leitura do texto. Busque a compreensão geral do mesmo não se preocupando com informações específicas ou palavras desconhecidas. Observe as informações que se destacam no texto (caixa alta, negrito, itálico, números, aspas, parênteses etc.) que o texto traz assim como os cognatos. (Cuidado com os falsos cognatos!!!!)

5. Leia as questões propostas com atenção e determine para cada uma delas uma palavra ou expressão-chave. A palavra ou expressão-chave deve ser algo que caracterize a alternativa. Ela não pode ser a palavra que mais aparece no texto. Lembre que essa técnica pode ser aplicada a um grande número de questões. Outras questões dependem única e exclusivamente da compreensão e da interpretação do texto.

6. Faça a $2^{a}$ leitura do texto. Esta deverá ser mais minuciosa, destacando as palavras ou expressões-chave que você escolheu.

7. Responda as questões, colocando a alternativa da questão e o trecho do texto onde se encontra a resposta em paralelo para uma possível comparação.

Observação: Caso o texto seja curto, você poderá inverter os itens 4 e 5, ou seja, ler as questões antes de ler o texto. Isto vai depender do nível de dominio da língua que você tiver.

Lembre-se:

Responda às questões de acordo com as informações explícitas ou implicitas no texto (inferência), jamais com base nas suas opiniões pessoais. ${ }^{7}$

7 S.J., A. Aluno deve ter um plano de ação definido para prova de inglês da UFPR. Gazeta do Povo on-line. Disponível em.: <http://canais.ondarpc.com.br/vestibular/dicas/conteudo. phtml?id=419051>. Acesso em: 6 fev. 2006. 
Um bom leitor/candidato faria a mesma trajetória sugerida pelo professor do cursinho? As ações propostas por ele são cabíveis somente para questões do tipo reconstituição de informação pontual linear. Que benefício 'destacar palavras desconhecidas' traz para o leitor/candidato? Não seria aconselhável orientá-lo a inferir o significado das palavras desconhecidas no contexto?

Procurar 'uma palavra ou expressão-chave' nas questões que servem para caracterizar a alternativa é uma estratégia equivocada. O candidato não deveria compreender o texto, e a partir de sua interpretação concentrar-se nas respostas sem se prender a uma palavra ou expressão? Apesar de muitas alternativas serem paráfrases de trechos do texto (comuns em exames de leitura de múltiplaescolha), isso não significa que o candidato deva desprezar palavras ou expressões ou valorizá-las. Tal estratégia pode levar o leitor/candidato a desconsiderar informações importantes ou supervalorizar informações desnecessárias.

Se na "dica" 5 o leitor/candidato deve enaltecer palavras ou expressões que "não pode ser a palavra que mais aparece no texto", como é que na "dica" 6 , ao fazer a segunda leitura do texto, ele deve "destacar as palavras ou expressões-chave que mais escolhera"? A "dica" 6 não contradiz a 5? A última "dica" somente é possível seguir se a questão for do tipo reconstituição de informação pontual e linear. Essa estratégia é impossível de ser usada em questões predominantemente do tipo argumentativo global não orientada. A resposta não será encontrada pontualmente no texto, uma vez que o leitor/candidato tem que ter uma compreensão global do texto.

Dicas e macetes propostos por professores de cursinhos geralmente preparam alunos apenas para provas de língua inglesa nas quais há uma predominância de questões do tipo reconstituição de informação pontual e linear. Exames bem elaborados, com questões predominantemente argumentativas suscitam estratégias de leitura que não se resumem em pinçar informações do texto. O leitor/candidato tem que ser hábil o suficiente para construir sentidos a partir de conhecimento da estrutura e do vocabulário da língua e, ao mesmo tempo, utilizar seu conhecimento de mundo, considerar o contexto sócio-histórico em que vive e perceber como o texto se organiza e funciona. Nas instruções do professor, não vemos a discussão sobre questões que levam o leitor/ candidato a inferir algo a partir do texto, nem sobre reconstrução da cadeia argumentativa do texto, e nem sobre a(s) intenção(ões) do autor do texto.

Portanto, a partir dessa análise, podemos prever que o exame de inglês do vestibular da UFPR poderá suscitar um ensino, que o precede, direcionado tão e somente ao treinamento de reconstituir informação pontual linear dos 
textos, além do ensino de gramática. Aspectos primordiais e desejáveis a serem abordados em aula tais como, a reconstrução da cadeia argumentativa, as inferências, a intenção do autor/texto, dentre outras, podem ser negligenciados, pois não são questões primordialmente trabalhadas no exame, e isso pode causar um efeito retroativo negativo.

O ensino de vocabulário também acontece de uma maneira bastante descontextualizada. Como podemos observar nas páginas 1 e 2 da apostila (Anexo C.6), o professor ainda utiliza listas de léxicos, exercícios de múltipla-escola, cloze e exercícios de relacionar palavras com desenho. Apesar de o professor dizer que trabalha o vocabulário através de temas - no caso do exemplo é o vocabulário médico - o ensino se dá de uma maneira descontextualizada. Não vemos uma relação dos pontos gramaticais ensinados anteriormente com o vocabulário, nem com interpretação de textos da área médica.

Vemos nitidamente o efeito retroativo do exame do vestibular, em termos de conteúdos, desde o primeiro até o último dia de aula, e nos textos escolhidos para serem trabalhados: muitos são de vestibulares anteriores de diversas instituições superiores, no planejamento da disciplina para o ano, no material didático, na ênfase que o professor dá para a leitura, e nos exercícios e provas que são no formato dos exames de vestibulares - múltipla-escolha simples e somatória. Podemos considerar como um efeito retroativo positivo o fato do professor eleger a leitura como a competência principal a ser desenvolvida. Porém, não se vê, por parte do professor, uma mudança significativa em sua concepção de língua e leitura. A gramática e o vocabulário ainda são abordados de uma maneira estruturalista e, muitas vezes, descontextualizados, e a leitura é trabalhada, primordialmente, de maneira ascendente. O nível de compreensão de texto a que se chega não passa de reconstituição de informação pontual linear. Isso pode ser considerado como um efeito retroativo negativo do vestibular da UFPR. Como os exames de inglês da UFPR possuem questões que na sua maioria são de reconstituição de informação pontual linear, nem o professor, nem a escola se deu conta de que uma boa aula de leitura deveria incluir outros níveis de compreensão de textos (ver seção 4.1.2). Portanto, podemos afirmar que por um lado o exame de inglês do vestibular da UFPR trabalha predominantemente com questões de reconstituição de informações e assim, não exerce influencia no ensino médio sobre a visão de leitura em um nível mais argumentativo. Por outro lado, as escolas e professores que preparam seus alunos para essa prova, não possuem um conhecimento aprofundado das concepções de linguagem, de leitura e de avaliação correntes para que eles possam suprir essa deficiência. 


\subsubsection{A apostila e as percepções de seu elaborador}

O elaborador da apostila do Colégio DB trabalha no desenvolvimento de material didático há seis anos. Ao escrever a apostila, ele direciona seu material para o aluno que tem "um histórico escolar mais deficiente, mas que possa, a partir do que ele sabe, alcançar o aluno do ensino particular: tarefa difícil, mas não impossível", segundo ele. O elaborador também leva em consideração os professores que utilizarão seu material: "um profissional que tenha uma formação necessária para poder ensinar o inglês e até uma certa vivência no idioma. Além disso, ele deve trabalhar de forma bastante criativa".

O objetivo maior do material didático é de preparar alunos para o vestibular da UFPR, bem como de outras instituições superiores locais e de outros estados como USP, Unicamp, ITA ou Estadual do Rio de Janeiro. Documentos oficiais como PCNs, LDB, dentre outros não são consultados para a elaboração do material. Como esclarece o professor:

PCN? Não é muito acessível. Mesmo assim o Colégio DB promoveu uma série de encontros com nossos professores com uma professora especialista sobre os Parâmetros para traduzir pra nós tudo aquilo, né? Para colocar tudo numa forma mais inteligivel. Interessante, interessante enquanto conceito. Mas não sei!!!! Não sei se dá pra... sei lá.... Não sei se dá pra considerar como eficiente. Não dá pra considerar como norteador, não.

Como podemos observar, o professor conhece as limitações dos documentos oficiais: "não é acessível", "precisa ser traduzido", "não dá pra considerar como eficiente" - e, por esse motivo os desconsidera. Os únicos documentos consultados são o programa do vestibular da UFPR, bem como os próprios exames de vestibulares da UFPR e de outras instituições. Segundo o elaborador, uma parte do material é aplicada ao ensino de gramática como apoio à compreensão de textos. Na verdade, o que podemos notar é que a apostila do curso regular é dividida, basicamente, em duas partes: uma dedicada ao ensino de gramática nos moldes do Método da Gramática-Tradução com explicações detalhadas dos pontos gramaticais, seguido de exercícios do tipo itens isolados, juntamente com exercícios de tradução (Anexo C). A outra parte é dedicada à compreensão de textos nos moldes ora com enfoque mais estruturalista ora com uma visão descendente de leitura. Ele procura diversificar variedades e tipologias de textos e questões, pelo fato de prepara os alunos para outros vestibulares do país. Ele afirma que "há muito conteúdo 
a ser trabalhado e, geralmente, um professor não terá tempo hábil para utilizar atividades complementares".

O professor pensa que a tarefa de escrever material para a prova de língua inglesa do vestibular da UFPR é difícil, pois ele não consegue estabelecer um padrão das provas. Ele reclama:

Engraçado. A cada ano essa prova apresenta uma surpresa nova. A impressão que tenho é que eles não conseguiram achar ainda um ponto de equilíbrio na prova. Algumas provas são extremamente difíceis, fogem totalmente da realidade do ensino da língua inglesa no Brasil, e outras que parecem ser até um pouco ingênuas em certos momentos. É por aí. A gente não consegue estabelecer um padrão de prova. É difícil você trabalhar assim. Pra nós é difícil. Você não consegue perceber uma seqüência lógica, uma evolução. Parece não haver um parâmetro lá dentro da universidade na confecção da prova, na elaboração da prova.

A dificuldade do elaborador de estabelecer um padrão de exame se deve ao fato do exame não ter seguir um padrão. Como já foi dito na seção 4.1.2, não há padronização no grau de dificuldade dos textos e questões. Alguns exames apresentam textos mais complexos que outros. Os tipos de questões também diferem de um exame para outro ora privilegiando o construto leitura (em um nível de reconstituição de informação) ora a estrutura da língua (como no exame de 2005). O professor advoga que a prova poderia ser mais exigente, "mais elaborada", pois já percebeu a falta de padronização. Porém "como o ensino da língua inglesa é deficiente no país, fica muito difícil querer avaliar algo que o ensino fundamental e médio não oferece". Como ele afirma, "existe talvez um modelo ideal de prova, mas existe também uma realidade que não pode ser também descartada. Fica um híbrido do ideal com o real. Totalmente deficiente". O modelo ideal para o elaborador seria um exame que avaliasse o construto leitura de maneira a selecionar os leitores/candidatos com uma proficiência tal que conseguissem ler os textos acadêmicos na graduação sem dificuldades. Porém, a realidade que ele se refere é a baixa qualidade do ensino de língua estrangeira no ensino fundamental e médio.

Não dá para balizarmos nosso ensino pelas deficiências do sistema educacional do país. Ao contrário, se um exame de vestibular, de boa qualidade, servisse de fato de balizador para o ensino que o precede nas escolas públicas e particulares; se houvesse diretrizes e planejamentos em sintonia com esse exame, e se a Secretaria da Educação trabalhasse junto com a Universidade para traçarem objetivos comuns, o nível das escolas, em geral, tenderia a melhorar. 
Apesar de achar que a prova de língua inglesa não seja compatível com a realidade do país, o elaborador acha que o exame avalia bem o candidato que utilizará a língua no mundo acadêmico. Ele também assevera que as provas de línguas inglesa e espanhola deveriam ser obrigatórias para todos os candidatos: o inglês pela universalidade da língua. Ele argumenta que "não há discussão nenhuma a este respeito, nem do quanto a língua é instrumental para o aluno que está entrando no mundo acadêmico, e o espanhol por sermos da América Latina e a língua ser utilizada como instrumento de aproximação e integração desses países".

O exame de vestibular é tão significativo para o Colégio DB que o elaborador acha que o vestibular da UFPR deveria ser um mecanismo para provocar mudanças no ensino fundamental e médio. O exame tem um caráter de 'shaping instrument' (instrumento que molda) e deveria ser o parâmetro para mudanças na base" [referindo-se ao ensino fundamental e médio]. Seu material didático foi totalmente moldado para o exame em termos de conteúdo, seleção e seqüência de atividades. Apesar do elaborador achar ótimo o exame não avaliar explicitamente a gramática, seu material contempla estruturas. Ele pensa que os professores que utilizam as apostilas podem fazer uma ponte do sistema lingüístico com a interpretação de um texto. Na verdade, se analisarmos a apostila, podemos perceber uma forte influência em termos de conteúdo, mas não em termos de metodologia. O exame de inglês da UFPR, apesar de avaliar a compreensão de texto com predominância informativa, a apostila dedica metade de seu espaço para o ensino isolado da língua.

\subsubsection{Os alunos do Colégio DB}

Os alunos que responderam ao questionário estão na faixa de idade de 16 a 22 anos. Somente dois deles trabalham de 12 a 30 horas semanais. Eles já estudam a língua de 3 a 12 anos. Alguns já moraram no exterior e aprenderam a língua fora do país ou cursaram inglês em institutos de línguas. A grande maioria afirma que o inglês aprendido na escola e no curso pré-vestibular foi suficiente ou ótimo, e garante-lhes uma boa nota nas provas de língua inglesa dos vestibulares. Uma pequena parcela de alunos ressaltou que a instrução recebida na escola não foi suficiente, mas que outros mecanismos como vídeogame e Internet foram importantes para que sua competência lingüística tivesse desenvolvido o bastante para enfrentar o exame. Todos disserem ter procurado o Colégio DB por ser considerado um dos mais renomados da cidade além de aprovar muitos candidatos no vestibular da UFPR. 
Ao ser questionada se o inglês da escola ajudará na aplicação da língua em futura carreira, a grande maioria disse acreditar que o inglês aprendido na escola e em curso pré-vestibular propiciará condições para usá-lo na futura profissão. Um pequeno grupo acha que eles necessitarão de instruções complementares para atingir o mesmo objetivo. Todos advogam a importância de dominar a língua inglesa, tanto para a vida acadêmica, como para suas carreiras futuras: uns a chamam de 'língua mundial', outros de 'língua dos negócios', 'língua da globalização' e 'a língua que o mercado de trabalho exige'.

Como a grande maioria dos alunos está bastante motivada em estudar na UFPR, ela está sempre buscando informações sobre o exame através de jornais, revistas, Internet e informativos dados pelo curso pré-vestibular. Os alunos acham que o vestibular da UFPR é um grande obstáculo a transpor, uma luta necessária para garantir um futuro no mercado de trabalho mais especializado e mais bem pago. Eis o que dizem alguns desses alunos:
"Uma garantia para um emprego melhor."
"Uma barreira que seleciona os mais bem preparados para cursa- rem uma faculdade."
"Será um marco de uma mudança na minha vida."
"Formação profissional importantíssima."
"Uma ponte para o inicio da minha carreira profissional."
"Uma fase de isolamento e dedicação intensiva."
"Diria que é o primeiro grande passo da minha vida, pois envolve o meu futuro profissional."
"É o melhor vestibular de Curitiba e oferece um bom mercado, ou seja, ele é bem aceito."

Os alunos com um grande grau de proficiência lingüística não gastam muito tempo estudando inglês para o vestibular, pois acham a prova de inglês do vestibular da UFPR ou fácil ou razoável. Os que têm um nível intermediário ou básico da língua passam algumas horas semanais se dedicando à língua apesar de achar a prova razoavelmente fácil. Dos alunos que estudam para a prova de inglês, todos se concentram em desenvolver estratégias de leitura sugeridas nas apostilas e a gramática. Os que têm menos conhecimento da língua se preocupam em desenvolver uma "boa base gramatical e lexical" como se tal estratégia de aprendizagem fosse efetivamente garantir que eles aprendam a interpretar textos: uma visão equivocada e estruturalista de que se a gramática e vocabulário forem aprendidos, a leitura será decorrente disso. 
A grande maioria dos alunos tem consciência de que a prova de língua inglesa do exame da UFPR avalia seus candidatos adequadamente, pois "explora ao máximo a capacidade lingüística através da interpretação de textos e a gramática implícita nas alternativas". Um aluno ressaltou que "o fato do exame não avaliar explicitamente a gramática evita a "decoreba" - excelente percepção do aluno. Outros alunos pensam que "a prova deveria ser direcionada às necessidades do curso que o candidato irá prestar, isto é, ser mais exigente dependendo do curso, cobrando inclusive outras habilidades como escrita ou fala". Outra fala bastante interessante e muito pertinente, pois mostra que o aluno tem consciência de que, dependendo do curso que ele cursará, ele terá que utilizar outras habilidades e competências não avaliadas no exame de vestibular. Por exemplo, no curso de Turismo, as outras habilidades - fala, compreensão auditiva e escrita - também deveriam ser cobradas.

Metade dos alunos salienta que o exame do vestibular pode ser, ou já é, um mecanismo eficiente de mudanças do ensino de inglês nas escolas de ensino médio. Uns dizem que:

- "o vestibular pode direcionar o ensino no sentido da verdadeira compreensão de textos e não da simples "decoreba" de regras gramaticais."

- "a língua passará a ser ensinada de uma forma mais eficaz para quem quer aprender."

- "as escolas devem visar o total empenho dos alunos na língua inglesa. É necessário que os alunos entrem no ensino médio sendo muito bem preparados."

Já outros alunos pensam que o vestibular não deveria influenciar tanto o ensino desenvolvido no ensino médio. São da opinião que:

- "as escolas condicionam-se a ensinar aos alunos somente o que o teste cobra e não um inglês 'para a vida'."

- "as escolas sempre procurarão somente focar os estudo para o que será pedido no vestibular."

Para esses dois últimos alunos, o exame de inglês do vestibular da UFPR não parece ser um instrumento (validade de face) que avalia as competências (validade de construto) que um futuro aluno universitário deveria possuir.

O fato do exame não avaliar mais 'decoreba', pois não avalia a gramática diretamente, deveria, a priori, inibir aulas de gramática aos moldes MGT - o 
que não foi observado nas aulas. Mas os alunos têm consciência de que provas que avaliam 'decoreba' não são de qualidade. Uma outra parte de alunos, porém acha que preparar para o vestibular causa limitações no ensino, pois não "prepara para a vida", ou prepararão os alunos "somente para o que será pedido no vestibular". Eles tocaram em um ponto interessante, pois a grande maioria das escolas que prepara seus alunos para o vestibular, trabalha somente a leitura e desconsideram habilidades importantes como a fala, a compreensão auditiva e a escrita: um fator limitador do vestibular que estreitam o currículo - efeito retroativo negativo.

A mudança do foco de avaliação da prova de língua inglesa da cobrança da gramática para a interpretação de textos gerou uma série de adaptações, segundo os alunos. Eles comentam que se esforçam muito mais para analisar e compreender os textos, além de tentarem aumentar seu conhecimento de vocabulário. Muitos alunos, que não conheceram as provas de gramática de inglês, já tinham o hábito de estudar textos e o exame somente veio reforçar tal prática. Todos foram unânimes em dizer que tanto o professor quanto a escola adaptaram suas aulas para a nova realidade do vestibular.

As expectativas de muitos alunos em relação ao aprendizado de língua inglesa - ênfase na leitura - convergem com a prática do professor e a filosofia da escola. As expectativas de alguns alunos em relação ao aprendizado da LE também convergem com as orientações do exame de LE da UFPR, isto é, ênfase na leitura. Outros alunos, porém, acham que as orientações do vestibular são limitantes, pois eles pregam que seria desejável que as outras habilidades - fala, compreensão auditiva e escrita - também fossem contempladas nas escolas.

Neste cenário, vimos que o Colégio DB desenvolve um trabalho em equipe entre diretor, professor e elaborador da apostila afinados no interesse em desenvolver(em) condições para que seus alunos tenham acesso ao ensino superior. Observamos que o programa oficial do vestibular da UFPR assim como as análises dos exames anteriores são utilizadas para definirem objetivos ao ensino da língua inglesa e documentos oficiais do MEC ou da SEED são desconsiderados. O exame, portanto, fez com que o diretor e professor se empenhassem mais no preparo das aulas e materiais didáticos, e, muitos alunos estudassem mais para a prova. O diretor do colégio exige de seus professores um planejamento da programação anual totalmente balizada pelo programa oficial do vestibular da UFPR. Segundo ele, o vestibular da UFPR é responsável pela existência do curso. O professor de inglês, que também é o elaborador da apostila utilizada no curso, compartilha do mesmo discurso do diretor: as aulas e as apostilas são desenvolvidas com um só objetivo: aprovar no vestibular da 
UFPR. Os alunos, por sua vez, procuram o colégio por ser considerado um dos que mais aprova alunos no vestibular da UFPR. Apesar de alguns exames apresentarem problemas, como afirmou o professor, os alunos não acham a prova um obstáculo muito grande. Todos os sujeitos deste cenário acreditam que o exame do vestibular é um eficiente instrumento direcionador do ensino médio apesar dos efeitos negativos que o exame possa exercer devido a falta de padronização de concepções de língua, de leitura e de avaliação da prova de inglês. A influência positiva do exame pode ser percebida pelo fato de ser o elemento que estabelece objetivos claros ao curso, apesar de ser possível questionar a possibilidade de estreitamento do currículo. Um outro fator positivo é que o professor/elaborador começou a priorizar a leitura que estava relegada ao esquecimento antes do vestibular mudar o foco para interpretação de textos. A influência negativa do exame pode ser notada pelo fato das aulas de inglês serem direcionadas para um nível mais superficial de leitura, uma vez que questões com predominância argumentativas são excluídas dos exames. O ensino de gramática aos Moldes Gramática-Tradução pode ter sido incentivado devido ao fato de algumas questões de língua serem avaliadas em alguns vestibulares. Um outro problema foi que muitos alunos concentraram-se no estudo da gramática e do vocabulário, sem fazer uma relação adequada dos conteúdos estudados com os textos. Além disso, pudemos perceber que há uma quantidade de conteúdos que a escola tem que cobrir em um curto espaço de tempo. Como há somente uma aula por semana de língua inglesa, o professor condensa uma grande quantidade de conteúdos em uma única aula. Se o aluno não souber a matéria de antemão, fica inviável aprender tanto em tão pouco tempo. Ainda, como a prova de língua inglesa do vestibular da UFPR avalia, na maioria das vezes, reconstituição de informação pontual, induz o professor a criar 'steps', ou seja, estratégias tais como 'colocar a alternativa da questão e o trecho do texto onde se encontra a resposta em paralelo, para uma possível comparação’. Esta estratégia pode levar ao candidato/leitor negligenciar outros tipos de questões nas quais as respostas não são encontradas pontualmente no texto, como a intenção do autor ou reconstituição da argumentação. O professor não teve a preocupação em aula de trabalhar outros tipos de questões com predominância argumentativa, o que revela um outro efeito negativo do exame.

Podemos concluir que o exame de inglês do vestibular da UFPR exerce uma grande influência neste cenário com alguns desdobramentos positivos e outros negativos como citados acima. Diferentemente das escolas públicas, o objetivo principal deste cenário é proporcionar aos seus alunos saberes que os levam a um nível mais elevado de estudo: a universidade. 


\subsection{ESCOLA PARTICULAR - O COLÉGIO DP}

Diferentemente do Colégio DB, que recebe um grande número de alunos a partir do ensino médio, o Colégio DP recebe alunos para o ensino médio que geralmente estudam nessa escola desde a pré-escola. Como o inglês é trabalhado desde o início do ensino fundamental, quando eles chegam ao terceirão seu conhecimento da língua é muito bom. A maioria dos alunos faz curso de inglês em institutos de língua, paralelamente ao da escola, e muitos fazem intercâmbio com países anglófonos.

\subsubsection{As orientadoras do Colégio DP}

Ao pedir uma entrevista com o diretor da escola - que é um padre - ele me encaminhou para as orientadoras da escola justificando que não poderia conceder uma entrevista, pois a parte pedagógica da escola não era de sua competência. De acordo com as informações das orientadoras, a escola optou por adotar as apostilas do Colégio Objetivo de São Paulo por trabalharem os conteúdos que serão cobrados nos vestibulares, com um custo/benefício interessante, segundo o diretor. Um dos panfletos da escola deixa seus objetivos claros.

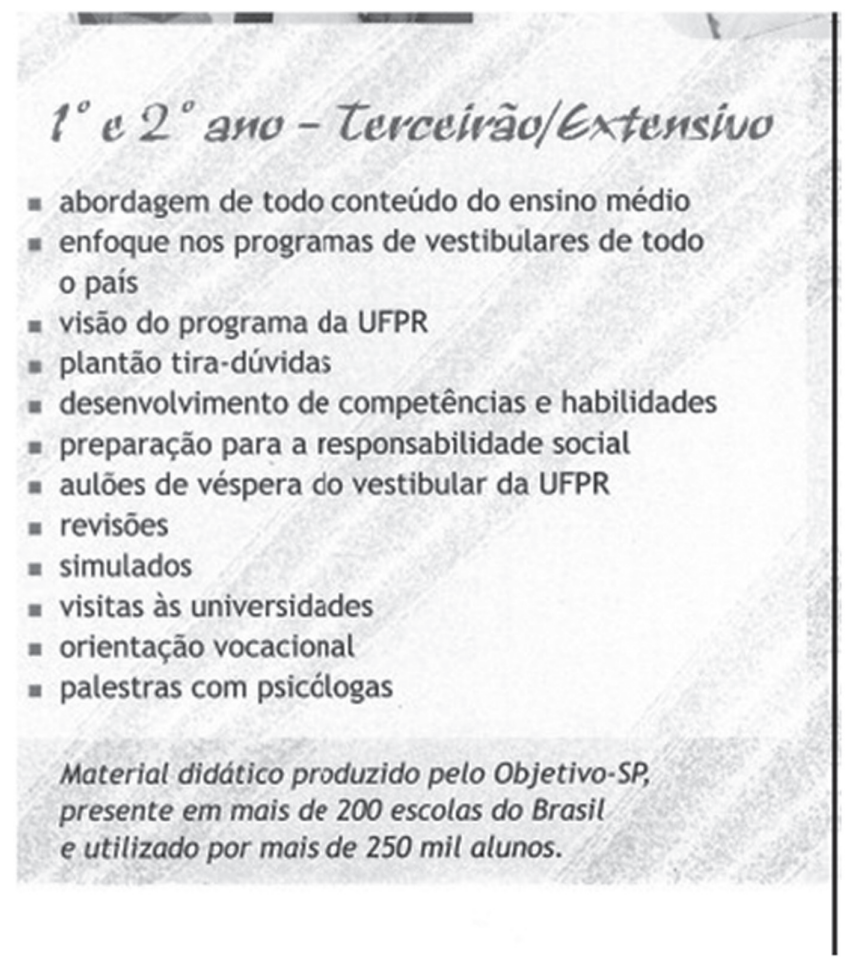


O panfleto mostra objetivos bem ousados, alguns praticamente impossíveis de serem atingidos, como "enfocar os programas de vestibulares de todo o país" - seria inviável incluir no planejamento anual todos os conteúdos contemplados nos programas de todos os vestibulares do país. Somente as listas de literatura obrigatórias para os vestibulares seriam muitas, com dezenas de livros para serem lidos em três anos de ensino médio. Se considerarmos, por exemplo, as listas da UFPR, UFSC e Unicamp-USP, o aluno do ensino médio teria que ler e estudar, somente para a disciplina de literatura, em três anos, 29 obras diferentes. Um outro item que chama atenção é o "desenvolvimento por competências e habilidades", conceitos fixados pelos PCNs. Como já pudemos observar anteriormente, no documento, não está claro o que seja competência e quais competências devem ser trabalhadas. O documento parece ser uma colcha de retalhos de fragmentações teóricas e há uma inclusão de várias concepções de linguagem - muitas vezes antagônicas. A escola, ao afirmar que trabalha para o desenvolvimento de competências e habilidades, não possui um conhecimento profundo e adequado dos documentos oficiais e nem as possíveis relações com o programa de inglês do vestibular da UFPR. "Abordagem de todo conteúdo do ensino médio" também é um item a ser questionado: todo conteúdo do ensino médio em relação a quê? Existe um documento, ou determinação Federal ou Estadual, que define quais conteúdos devam ser trabalhados no ensino médio? Se a escola opta pelos conteúdos dos programas dos vestibulares, então esse universo seria "todo conteúdo do ensino médio"?

Nem os professores, nem os coordenadores e os orientadores tiveram participação na escolha do material, apesar do diretor ter dito inicialmente, quando pedimos uma entrevista, que assuntos pedagógicos eram de competência das orientadoras. Uma das orientadoras explica:

Quando entrou o material do Objetivo, foi a instituição que escolheu e optou por esse material. Existe um departamento pedagógico que analisa e estuda... mas pra escolha desse material especifico não houve uma participação dos professores. O que nós temos feito desde que o Objetivo entrou na escola é avaliar, com os professores, outros tipos de material também. Outras apostilas, outros métodos... que a gente está acompanhando mesmo e colocando em discussão.

A participação da instituição no planejamento e, conseqüentemente, nas aulas é marcante, uma vez que todos os professores têm a obrigação de desenvolver as atividades propostas pelas apostilas. Os professores têm a liberdade de solicitar materiais complementares que serão fornecidos após avaliação da 
orientação. Portanto, apesar da escola dizer que a coordenadora e orientadora, bem como professor, têm liberdade para ensinar, tudo o que é ensinado passa pelo crivo de um pequeno grupo.

Como a escola direciona seu ensino médio para os vestibulares do país e em específico para o da UFPR (ver panfleto: "visão do programa da UFPR"), foi-lhes perguntado como eles tinham acesso às informações sobre o vestibular da UFPR. A escola divulga que prepara seus alunos para o vestibular da UFPR, mas, apesar disso, as orientadoras afirmaram que os professores têm dificuldade em conseguir informações a respeito do exame de vestibular da UFPR. Elas disseram que "os professores têm informações através de colegas mesmo. Eles têm essa interação". Segundo elas, os professores recorrem aos colegas de outras instituições para obterem informações sobre o exame, além de entrarem nos sites oficiais da universidade e lerem jornais e revistas locais. Então, podemos ver que a responsabilidade de procurar informações sobre o programa da UFPR é do professor, e não da escola, como acontece no Colégio DB.

Ao serem questionadas sobre o papel do vestibular da UFPR na vida de seus alunos e professores, elas falaram como a instituição da Federal conserva um status entre as classes A e B, além de ser uma porta de entrada para o restrito mercado de trabalho da cidade. Por essas razões, há uma preocupação exacerbada em ser aprovado nesse exame.

O que a gente percebe é justamente aqui, né?... o fator econômico e o status que a Federal dá. Apesar de muitos cursos na Federal não estarem com grade curriculares atualizadas. Isso eu sei por experiência porque meu filho faz desenho industrial. Está muito aquém do que de repente uma Universidade Federal de Santa Catarina oferece. Mas.... passar na Federal... ser graduado pela Federal dá um certo status e pros alunos em geral abre como... uma porta no mercado de trabalho.

Segundo as orientadoras, mesmo com tantas instituições de ensino superior particulares abrindo a cada ano, a escola tenta mostrar aos alunos o perigo de se cursar uma faculdade ou universidade particular sem qualidade e rigor no ensino e, muitas vezes, sem o reconhecimento do MEC.

Ao serem perguntadas sobre suas opiniões sobre a prova de língua inglesa do exame do vestibular da UFPR, as orientadoras asseguraram que a prova não é difícil para seus alunos, uma vez que eles têm aulas da língua desde o ensino fundamental até o último ano do ensino médio, além de fazerem intercâmbio e cursos de línguas estrangeiras em institutos de línguas. 
As orientadoras acham, porém, que a prova de inglês da Federal não avalia adequadamente seus candidatos. Uma delas justifica sua opinião baseando-se em uma experiência de aula de instrumental na qual ela teve oportunidade de conhecer muitos alunos, que se graduaram na UFPR e que tinham entrado no mestrado e doutorado da instituição, tendo bastante dificuldade com os textos tanto das aulas, como das provas de proficiência de língua estrangeira. Segundo ela, se eles tivessem mais conhecimento da língua, eles não estariam se 'batendo' tanto com a prova de proficiência que se assemelha ao do vestibular. Na verdade, podemos questionar sua fala, pois muitos alunos que ingressam na pós-graduação não necessariamente passaram pela graduação da instituição, e os que passaram, provavelmente, fizeram vestibular quando o exame avaliava a gramática e não a compreensão de texto, ou foram os candidatos que passaram com uma nota de língua inglesa bem baixa. Scaramucci (comunicação pessoal) comentou que o mesmo problema ocorre na Unicamp. Ela já teve, em suas aulas de instrumental, alunos que haviam sido aprovados no vestibular com notas bem baixas de língua estrangeira, e, por esse motivo, tinham bastante dificuldade com as leituras em inglês. Seria um fenômeno para ser futuramente investigado.

Ambas as profissionais pensam que o exame do vestibular poderia ser um mecanismo eficiente de mudanças do ensino de inglês no ensino médio, se o exame fosse "democrático", "se partisse de uma discussão", "se [os profissionais do ensino médio] tivessem acesso a esse grupo [as pessoas que definem o programa e aos elaboradores do exame] para discutir qual é realmente a intenção, o que se quer de fato e os objetivos [do exame]". Para elas, a dificuldade de se conseguir qualquer informação mais precisa sobre o vestibular torna seu trabalho de preparar seus alunos para tal exame muito difícil.

Embora a aprovação de seus alunos na UFPR não seja muito alta, os professores preocupam-se em buscar informações sobre os vestibulares da cidade para poderem inovar. Sabendo das exigências do vestibular da UFPR, a professora de língua inglesa, segundo as orientadoras, tem trabalhado exaustivamente a interpretação de textos bem como vocabulário. A professora não participou da escolha da apostila que a escola adotou, mas "ela não faz da apostila um fim, mas um meio para aprendizagem e aí ela complementa o que falta". Sua preocupação é tão grande em preparar seus alunos para o exame que ela adaptou sua metodologia em sala de aula - ela transformou o seu ensino de gramática - ela é apresentada juntamente com o vocabulário de forma contextualizada, isto é, aplicada ao contexto de um texto; o conteúdo ensinado em sala - enfoque em interpretação de texto e vocabulário; e seus testes privilegiam a múlti- 
pla-escolha simples e somatória, tal qual o vestibular: "A escola aplica simulados semanais da matéria da semana no formato de somatória e múltipla-escolha simples".

Portanto, as orientadoras mostraram uma preocupação real em oferecer aos seus alunos um ensino dirigido para o vestibular. Porém, suas queixas são a falta de acesso às informações detalhadas sobre os objetivos específicos de cada prova do exame e acesso ao que o exame realmente almeja de seus candidatos. Elas disseram:

Eu vejo dessa questão da importância de se ter pelo menos um veículo de comunicação [entre universidade e ensino médio] seja via Internet ou comunicado, enfim de que pudéssemos participar desse grupo [de professores que foram convidados para as reuniões - oferecidas pelos elaboradores das provas - na universidade para falarem sobre a prova de língua estrangeira do vestibular da UFPR] onde se tem mais clareza desses objetivos. Eu acho que isso seria como uma solicitação, uma necessidade até pra que a escola tenha mais clareza e oportunidade de discutir realmente se esse é o caminho correto. Podemos ter boa vontade, mas não estamos no caminho correto. E eu valorizaria a equipe de professores que vejo enquanto iniciativa eles têm muita vontade de buscar, de fazer os cursos. Então tudo que pudesse fazer e correr atrás seria bem interessante com apoio da universidade.

O discurso das orientadoras em relação ao acesso à informação sobre o exame de vestibular da UFPR difere muito do discurso do diretor do Colégio DB. Primeiramente, muitas informações sobre o exame, tais como quais conteúdos abordados nos exames, qual a abordagem implícita nas provas, grau de dificuldade e até mesmo que metodologia melhor caberia para adaptar as aulas que antecedem o exame, podem ser inferidas de uma análise detalhada de exames anteriores. Uma prática feita pelo Colégio DB, mas não pelo DP. E segundo, precisaríamos averiguar como e por que o Colégio DB tem melhor acesso às informações sobre o vestibular, ao passo que as escolas públicas e o Colégio DP não. Seria porque o Colégio DB vai até a universidade procurar informações no núcleo de concursos e o Colégio DP, não? As reuniões que a UFPR fez com professores de LE de ensino médio durante três anos consecutivos foram publicados no jornal da cidade, segundo o coordenador do núcleo de concursos da UFPR. Por que poucos professores da cidade participaram dos eventos? 
Através do discurso das orientadoras do Colégio DP, pudemos perceber que a escola cobra resultados dos professores em termos de aprovação de seus alunos no vestibular da UFPR, porém lhes é dada pouca autonomia para pesquisar e escolher os materiais mais adequados.

Há vários vestibulares de instituições públicas renomadas no país. Se as escolas de ensino médio se preocuparem em contemplar todos os programas de vestibular dessas instituições, elas acabarão perdendo o foco, pois a quantidade de conteúdos a serem trabalhados é muito grande para serem ensinados somente em três anos de ensino médio. Porém, no caso de língua inglesa, a maioria desses exames avalia a proficiência de leitura e, portanto, basta o professor escolher ou elaborar um material bem estruturado, seqüenciado desde a $5^{\text {a }}$ série do fundamental até o $3^{\circ}$ ano do ensino médio e ter uma estrutura boa com poucos alunos para prepararem seus alunos tanto para o mercado de trabalho como para qualquer vestibular do país.

\subsubsection{As percepções do professor do Colégio DP}

A professora descreve o perfil de seus alunos como sendo das classes A, B e C. Muitos deles têm acesso a cursos de inglês fora da escola. Dominar a língua inglesa para essa comunidade é um instrumento importante, tanto para a futura vida acadêmica como para a profissional. Porém as aulas do colégio não têm o mesmo prestígio que as aulas de institutos de línguas. A professora se queixa que as atenções vão para outras disciplinas como a Matemática, Física e Química. Quando há duas ou três provas no mesmo dia, os alunos estudam para as outras disciplinas em detrimento da língua inglesa e quando há somente a prova de língua a tendência é os alunos irem melhor na avaliação. Alguns fatores contribuem para essa situação: "muitos sabem que podem aprender a língua fora da escola, e como há uma heterogeneidade grande entre os alunos, os que sabem mais tendem a negligenciar as aulas pensando que sabem ler e interpretar textos", o que, muitas vezes, pode não corresponder à realidade. Muitos cursos externos de língua estrangeira não têm a preocupação em desenvolver a habilidade de leitura no nível de exigência do exame do vestibular, e, por esse motivo, os alunos que superestimam seus conhecimentos na língua estrangeira acabam, às vezes, não tendo bom desempenho no exame de LE do vestibular.

A escola adotou as apostilas do Colégio Objetivo de São Paulo por questões financeiras e didáticas, segundo a professora, percepção compartilhada pelas orientadoras. Ela chama a atenção para o fato de a apostila ter sido escrita 
para os vestibulares de São Paulo e não dirigidas para o vestibular da UFPR. Enquanto as outras escolas particulares e cursos pré-vestibulares trabalham com os textos dos exames anteriores, ela tenta suprir tal deficiência com materiais complementares, pois sabe que cada vestibular possui questões regionais:

Mas as partes mais regionais ficam de fora. Em $S^{\text {ta }}$ Catarina...tem muito regionalismo no vestibular. Nossa senhora!!!!! Em Geografia, mesmo em Português, os poetas, os da terra... é complicado isso para o aluno. Eu vejo isso porque tem aluno que vai fazer vestibular em $S^{\text {ta }}$ Catarina. Eu pego as provas para ver...é complicado. E as apostilas não dão conta disso. Em Sta Catarina caíram questões de autores que eu nunca tinha ouvido falar..QQuem não é da região, não sabe.

O vestibular da Universidade Federal de Santa Catarina elabora um exame voltado para História, Geografia, Literatura, Cultura e Notícias locais. As escolas de ensino médio do estado trabalham com os conteúdos regionais para privilegiam seus alunos. Como a Universidade é federal, isso pode provocar um efeito retroativo negativo, pois pode causar um estreitamento curricular (ver item 2.4.1.2) muito grande nas escolas.

Para atender a demanda do vestibular da UFPR, a professora trabalha textos com temas que mais aparecem nas provas, pois através desses temas ela enfatiza o vocabulário mais recorrente. Recentemente, ela enfatizou, por algumas semanas, textos relacionados à guerra por causa das guerras no Oriente Médio. No ano retrasado, o assunto em voga dos textos era o acontecimento de 11 de setembro. Os textos são tirados de fontes diversas como livros, revistas, jornais ou Internet. Segundo a professora: "onde vejo um texto em inglês, eu xeroco". Há uma preocupação em complementar as atividades da apostila com textos da atualidade. Vocabulário, gramática, marcadores, cognatos, falsos cognatos são elementos focalizados nos textos escolhidos.

Ela também tem a preocupação em "treinar" seus alunos para o formato do vestibular. Como ela diz "é treinamento mesmo" - o que poderíamos considerar um efeito retroativo negativo. Suas provas são de múltipla-escola simples ou somatória. Ela mostra sua preocupação quando diz:

Quando entrou o sistema de somatória... não tem em livros...então você tem que ficar convertendo, aumentando questão... é um saco. Um dia, numa tarde eu fui até a biblioteca pública, peguei os jornais - porque eles têm todos os jornais lá, né? - peguei desde a época que começou a somatória, separei tudo, xeroquei...deu uma trabalhei- 
ra...foi uma confusão de folha, jornal, e xeroca e emenda. Deu uma trabalheira isso.... mas fiz isso. Agora eu compro o jornal no dia e vou guardando.

Sua preocupação em 'treinar' seus alunos para o formato da prova é percebida quando ela compara o Colégio DP com o outro colégio no qual ela leciona. No outro colégio, os alunos fazem prova de múltipla-escolha somatória desde o primeiro ano do ensino médio, inclusive com cartão resposta igual ao do vestibular. Erros nos cartões são permitidos somente no primeiro ano. A partir do segundo ano, os cartões não são mais trocados quando há erros para forçar seus alunos a "criarem o hábito de fazer uma prova dessas".

Suas aulas, portanto, são planejadas de acordo com as apostilas do Objetivo e com os vestibulares da UFPR e UFSC. A escola exige que todos os professores sigam as apostilas, mas os professores podem complementar suas aulas com materiais que estejam de acordo com o programa proposto pelo material adotado.

Como o vestibular é um exame importante para a escola, professores e alunos sempre tentam se informar sobre os vestibulares locais. Há muita troca de informação entre colegas de outras escolas particulares: "professores de um cursinho vêm e falam alguma coisa, outra dá uma novidade". O Colégio DP nunca soube das reuniões que ocorriam no Departamento de Línguas Estrangeiras Modernas com professores de cursos pré-vestibulares e ensino médio. Ela comenta:

Eu nunca participei de reunião nenhuma. Nunca fui chamada para participar de uma reunião específica de língua estrangeira da UFPR. Seria muito bom. Mas isso não pode... deveria ter para todos, né? Foi o Jomar que foi e me contou. Dai esse ano ele não foi chamado...geralmente acontece em maio essas coisas. Ele queria saber o que tinha acontecido. Ele é do Colégio, né. Nós não sabemos se não teve ou se não fomos chamados. Eu gostaria de ter mais respaldo da Federal. Espero que eles tenham essa preocupação com os professores que preparam os alunos pro vestibular...não simplesmente jogar isso ai. No português eles dão uma lista de livros. No inglês não tem isso... 'olhe, procure mais textos ou revistas centradas nisso' ...então eles não direcionam. Não direcionam nada, nada, nada, nada. Acho que eles poderiam montar um esquema que pudesse direcionar um pouco mais a prova do inglês, já que eles só querem textos. Sei lá dá uns dez temas e dentre eles caem dois relacionados. Porque dai eu 
fiquei aqui: preparei, preparei a turma com vocabulário de guerra, eu insisto: "Olha pessoal, fique atento! E não caiu nada de guerra, entendeu? Então isso poderia acontecer: um assunto importante que aconteceu no ano...Eles não têm essa preocupação.

Essa queixa também foi feita pelas professoras das escolas públicas e professores dos cursos pré-vestibulares populares. Segundo o coordenador do núcleo de concursos da UFPR, tais reuniões eram publicadas em um jornal local, apesar de que eu mesma, professora de inglês no ensino médio público, nunca ter visto essa convocação. O que parece é que os professores e diretores que têm um vínculo pessoal maior com o núcleo de concursos da UFPR conseguem ser melhores informados a respeito do exame de vestibular.

Interessante a professora advogar que a prova de língua inglesa poderia direcionar mais o ensino da língua no ensino médio, como a literatura faz. Ela toca numa questão interessante quando diz que "eles (os elaboradores) deveriam estipular temas para serem trabalhados", pois tal demarcação poderia ajudar a focar mais o trabalho do professor. O ensino de vocabulário através de temas específicos, para a professora, seria facilitado se os elaboradores concentrassem seus textos em alguns temas. Porém, na minha visão, um bom leitor de LE deveria conseguir um bom desempenho no exame independente do tema, e a demarcação de temas poderia estreitar demasiadamente o currículo, além de não oportunizar o professor a trabalhar a inferência de significados de vocabulário desconhecido através do contexto. Mesmo assim, a questão da professora deveria ser uma, dentre outras, a ser debatida entre universidade e escolas.

O vestibular para ela é um instrumento de seleção muito importante. Ela vê a necessidade de classificar e selecionar somente os alunos mais preparados, pois "nem todos alunos levam os estudos a sério". O vestibular tem que "separar o joio do trigo". Há aqueles alunos que têm consciência da importância do estudo, do esforço, mas há uma grande maioria que não tem os estudos como prioridade. A professora descreve o comportamento de seus alunos nos simulados: "[...] é duas horas de prova e eles começam a sair porque eles querem ir para o shopping! A primeira e segunda fileira do curso assistem às aulas, o restante está lá para cumprir tabela".

Para os alunos que levam o ensino médio a sério e que já estudaram inglês fora da escola, a prova de língua inglesa do vestibular da UFPR não é difícil. Entretanto, para aqueles alunos que não têm um bom desempenho escolar, a prova é bem difícil. A professora acha que para ser bem sucedido no exame, 
o candidato tem que ter um bom domínio da língua: "Não dá para enganar. Quem consegue ir bem numa prova de vestibular de inglês, tem que ter um domínio. O cara não vai conseguir fazer aquela prova...você não consegue chutar...não tem como". Isso mostra que a prova está discriminando bem quem tem a competência e quem não tem.

Os textos que a UFPR utiliza, segundo a professora, são difíceis de serem avaliados, pois ora são "muito científicos" e "muito pesados", ora são mais fáceis e, às vezes, "muito longos e complexos". "Muitas vezes não dá nem para os candidatos terminarem a prova". Sentimento também compartilhado pelo professor e elaborador de apostila do Colégio DB. A professora acha que o exame deveria voltar a avaliar a gramática porque:

[...] querendo ou não as escolas.... a gente, a vida inteira, ensina a gramática pra eles, entendeu? E a gramática, querendo ou não, faz parte...se você não souber...você pode ler e tudo, mas você tem que saber a gramática. A gramática é uma das coisas que te ajudar a entender o texto. Não 100\%, talvez metade, metade, mas acho que tinha que ter uma parte sim para gramática. Até pra deixar ele mais relaxado, deixar ele mais confiante.

Ao mesmo tempo que a professora afirma que o exame discrimina bem, ou seja, seleciona somente os alunos que têm uma boa proficiência em leitura, ela se paradoxalmente advoga a volta da cobrança da gramática descontextualizada. Fica claro que ela ainda está atrelada a uma visão de língua e de leitura estruturalista. Ao meu ver, se a professora tivesse trabalhado com esses alunos desde o $1^{\circ}$ ano do ensino médio por competências, integrando as quatro habilidades e, trabalhando a gramática da língua em cada contexto abordado, os alunos chegariam no terceiro ano do ensino médio com um bom conhecimento sistêmico e desempenho da oralidade e leitura suficiente para enfrentar o exame de inglês do vestibular com tranqüilidade.

A professora diz que os alunos se queixam que a prova de interpretação de textos exige muito do candidato. Eles não somente têm que dominar a gramática como o vocabulário, as estratégias de leitura. Para eles a prova "ficou muito mais difícil" do que as provas de gramática. Visão também compartilhada pelos professores das escolas públicas. Essa queixa se deve ao fato de poucos alunos conseguirem atingir um nível de proficiência da língua satisfatória. O professor do Colégio DB também havia dito que o exame não condiz com o nível do ensino médio no Brasil. Porém, a universidade não pode nivelar seu 
exame por baixo, ou seja, não dá para a universidade voltar a cobrar a gramática somente para facilitar ou simplificar a prova. O exame deve continuar a discriminar somente aqueles candidatos que saibam ler, e não aqueles que memorizam regras gramaticais. A continuidade da cobrança da leitura pode ser visto como um efeito retroativo positivo. Ele força os professores e escolas a irem atrás de material, conteúdo e metodologia que melhorem o desempenho de leitura de seus alunos.

Por isso, a professora se preocupa muito com o ensino de compreensão em leitura com o ensino de vocabulário e gramática aplicada aos textos. Ela comenta que desde as mudanças do vestibular ocorridas em 1995, ela teve que gastar muito mais tempo para preparar suas aulas, pois passou a ler e interpretar todos os textos e a estudar todo vocabulário, além de procurar textos e vocabulário relacionados aos assuntos da atualidade. Obrigar o professor estudar mais e se dedicar mais para o ensino de interpretação de textos é um efeito retroativo positivo.

Ao ser indagada se o exame pode ser um mecanismo eficiente de mudanças no ensino de inglês nas escolas de ensino médio, ela afirmou que querendo ou não "você acaba mudando e se adaptando para o vestibular, e que a força do exame está longe do alcance do professor ou da escola", ou seja, esses profissionais nada podem fazer para impedir tal fenômeno, pois a força do exame é mais forte do que a vontade desses profissionais - "nós estamos à mercê do exame". Tal observação nos mostra que a professora tem uma visão negativa do exame, inexorável e determinista. Ela está à mercê do vestibular e nada pode fazer a não ser preparar seus alunos do modo que ela vem fazendo com gramática, vocabulário e textos. Na verdade, se ela conhecesse as concepções correntes de linguagem, de leitura, as novas tendências no ensino de LE ela poderia preparar seus alunos para desempenhar tarefas orais, de leitura e de escrita para situações futuras de trabalho e de exame de vestibular. Apesar da força que o vestibular da UFPR tem exercido nas escolas cuja preocupação maior é de aprovar seus alunos no vestibular, essa força tem sido diluída pelo número grande de novas instituições de ensino superior que vêm surgindo. Os alunos já não têm tanta preocupação de não ser bem sucedido no vestibular da UFPR, pois com tantas novas universidades e faculdades, a oferta de vagas acaba suprindo as necessidades daqueles candidatos que não conseguem entrar na Federal. O Colégio DP, no entanto, resolveu implementar uma avaliação semanal das disciplinas para forçar seus alunos a criarem o hábito de estudo regular, o que poderia encadear um efeito retroativo positivo: fazer os alunos 
estudar mais. A maioria dos testes é elaborada no formato dos exames do vestibular. Para a professora, o novo sistema de avaliação realmente induziu os alunos a estudarem sistematicamente, porém o professor ficou sem tempo para propor qualquer atividade diferente daquelas da apostila.

Nas duas escolas particulares, tanto os diretores/orientadores quanto os professores têm um comprometimento grande em preparar seus alunos para o exame do vestibular da UFPR. Tudo gira em torno do exame: material didático, conteúdo ensinado (os textos trabalhados em sala de aula), concentração no ensino de leitura, gramática e vocabulário. Apesar dos professores acharem o exame difícil para alunos do ensino médio, muitos desses alunos têm um bom desempenho nos testes simulados, pois já cursaram o idioma em cursos de línguas ou fizeram intercâmbio.

A universidade ainda está muito distante dos professores e das escolas particulares e públicas. Mesmo advogando que não tem nada a ver com o ensino médio, ela acaba influenciando, pelo menos na grande maioria das escolas particulares, o ensino que a precede. Já que o efeito retroativo acontece, a participação da universidade no ensino médio seria imprescindível para que o efeito fosse benéfico a todos.

\subsubsection{As aulas do professor do Colégio DP}

Como já dissemos, a professora do Colégio DP trabalha com a apostila do Colégio Objetivo que, segundo ela, é dirigida para preparar os alunos para os vários vestibulares do país. Ela trabalha em três frentes: a gramática, o vocabulário e interpretação de textos, como o professor do Colégio DB. A apostila apresenta um resumo de um ponto gramatical em uma página (Anexo D.1). Na página seguinte, um texto é apresentado (Anexo D.2). Logo em seguida, exercícios de gramática, vocabulário e interpretação são trabalhados. Os exercícios de gramática são elaborados a partir do tema que o texto apresenta, nesse exemplo é "comportamento - amor" - (Anexo D.2). Os textos da apostila são agrupados por temas como Bio/Exatas, Humanas etc. Ao final de cada série de textos do tema, há uma questão de prova de vestibular, geralmente de São Paulo (Anexo D.2., p. 148). Como a apostila apresenta somente resumos dos tópicos gramaticais, a professora traz para as aulas explicações e exercícios complementares tanto em papel, quanto eletronicamente, quando os alunos são levados ao laboratório de informática para desenvolverem exercícios gramaticais. Tanto as explicações, quanto os exercícios propostos, são da era estruturalista, na qual somente itens de pontos isolados da língua são apresentados: múl- 
tipla-escolha, cloze e relacionar colunas são bastante comuns nos exercícios e nas provas. Ao trabalhar o vocabulário (Anexo D.2. p. 131), a professora traduz todas as palavras para o português, como nos tempos do Método Gramática-Tradução. A gramática também é ensinada como na era estruturalista. O enfoque dado à gramática é bastante parecido com o do professor do Colégio DB. A interpretação de textos é feita em língua materna e as alternativas são lidas em inglês e, às vezes, traduzidas. Como a maioria dos alunos não se mostra interessada nas aulas, a professora parece fazer um monólogo. Ela faz perguntas, e, geralmente, ela mesma tem que responder as questões. Às vezes, um ou outro aluno decide participar e responde algo que lhe foi perguntado.

A aula do dia 19 de agosto de 2003, por exemplo, começou quando a professora colocou na lousa um quadro com os modais:

\begin{tabular}{|c|c|c|c|c|}
\hline Present & Past & Future & Use & Translation \\
\hline $\begin{array}{l}\text { can } \\
\text { to be able to } \\
\text { am, is, are }\end{array}$ & $\begin{array}{l}\text { Could } \\
\text { to be able to } \\
\text { was, were }\end{array}$ & will be able to & $\begin{array}{l}\text { capacity } \\
\text { ability } \\
\text { informal } \\
\text { permission }\end{array}$ & poder \\
\hline may & Might & will be possible & $\begin{array}{c}\text { possibility } \\
\text { probability } \\
\text { formal permission }\end{array}$ & poder \\
\hline \multirow[t]{2}{*}{$\begin{array}{c}\text { must } \\
\text { have to }\end{array}$} & had to & will have to & $\begin{array}{l}\text { obligation } \\
\text { deduction }\end{array}$ & dever \\
\hline & $\begin{array}{l}\text { should } \\
\text { ought to }\end{array}$ & & $\begin{array}{c}\text { advice } \\
\text { deduction }\end{array}$ & deveria \\
\hline
\end{tabular}

- $\quad$ mustn't = estar proibido (prohibition)

- a negative de must é don't have/doesn't have to

- $\quad$ can = cannot or can't

- $\quad$ may = may not

Nenhum aluno copiou o quadro da lousa e nem prestou atenção na explicação da professora. Ela leu os verbos modais em português do quadro e traduziu os exemplos que forma escritos ao lado do quadro:

Ex.: She ought to visit her parents.

Ought she to visit her parents?

Depois da breve explicação, ela pediu para que os alunos abrissem a apostila (ver D. 2 p. 115) e observarssem a tabela. Depois, pediu para eles lerem a página 130 e fazerem os exercícios da 131 (ver Anexo D.2): exercícios de vocabulário (20 palavras para traduzir), interpretação do texto (3 questões) e 
gramática (4 questões). Os alunos somente começaram a fazer alguma coisa na aula quando a professora pediu para eles resolverem os exercícios da apostila. Após uns 15 minutos, ela leu o texto em voz alta, traduzindo alguns trechos e, logo a seguir, respondeu as questões de vocabulário, gramática e interpretação.

Como a escola cobra resultado dos professores no sentido de aprovar o maior número de alunos no vestibular, percebemos que a professora tem uma preocupação imensa em preparar seus alunos, que, em sua maioria, não têm o mínimo interesse em participar da aula e assistir a ela. Tenta motivá-los, então, com música e atividades extras. O professor do Colégio DB sofre a mesma pressão e se utiliza das mesmas estratégias - música, vídeos, etc - para motivar seus alunos.

Toda sua aula é direcionada para o vestibular e preparada de acordo com a apostila, os programas dos vestibulares da cidade, assim como exames antigos de instituições do sul, como Universidade Federal do Paraná, Universidade Federal de Santa Catarina, Universidade Estadual de Ponta Grossa, Universidade Estadual de Londrina e Maringá. Nenhum documento oficial como PCN ou LDB são consultados para planejar suas aulas. O professor do Colégio DB percorre, exatamente, o mesmo percurso da professora: não utiliza nenhum documento oficial para planejar suas aulas e utiliza os programas das universidades públicas locais para planejar suas aulas. Percebemos que o exame de vestibular da UFPR influenciou parcialmente as aulas, pois a professora direcionou seu ensino para a leitura e vocabulário, apesar de estar fortemente comprometida com o ensino de gramática descontextualizada. O mesmo acontece com o professor do Colégio DB. A professora prepara simulados do exame, nos moldes da UFPR, e aplica-os a cada bimestre. Apesar disso, na prática, a prova não se parece com a da Federal (Anexo D.3), pois avalia itens isolados de vocabulário, e às vezes, gramática. Os textos também são, em geral, didáticos. As provas do Colégio DB também avaliam gramática com itens isolados descontextualizados.

\subsubsection{A apostila do Colégio DP e as percepções de seu elaborador}

Apesar de escrever material didático há muitos anos, o professor reclama que o ensino de língua inglesa está cada vez mais desprestigiado nas escolas de nível fundamental e médio. Ele protesta dizendo: "Eu chamo [a disciplina de língua inglesa] de banquinho (ri)!!!! Inglês não é uma cadeira." O professor é absolutamente consciente que ele trabalha com uma disciplina cada vez menos valorizada nas escolas de ensino médio o que, para ele, é muito ruim: 
Eu notei a decadência de anos atrás. Até em número de aulas no ensino médio e no cursinho, diminuiu muito. Eu cheguei a ter no terceiro colegial, uma aula por semana. UMA! Matemática tem seis, português tem oito e inglês tem uma. Quando caía num feriado, a gente ficava duas semanas sem aulas. Cansei, batalhei muito, briguei muito... pulei na mesa, mas... cansei... cansei...

Quando o elaborador começa a escrever seu material didático para o ensino médio, ele direciona suas apostilas para alunos do ensino médio, razoavelmente preparado antes, no fundamental, com um nível de no mínimo intermediário. ${ }^{8}$ Ele justifica sua decisão no fato de que somente escolas particulares, inclusive o Colégio Objetivo, utilizam seu material e esse tipo de aluno vem da "classe A, A" como ele os classifica. O perfil dos professores que ele tem em mente quando elabora seu material é o de profissionais que "dominam a língua com proficiência". O objetivo de seu material é de preparar os alunos para vestibulares como a Fuvest, Unicamp, Vunesp, ITA e GV que na sua opinião são exames muito parecidos: avaliação de compreensão em leitura sem exigência de itens gramaticais explícitos. O vestibular da UFPR é totalmente desconhecido do elaborador do material usado no Colégio DP. As apostilas do professor concentram-se na "leitura de textos, compreensão de textos e o ensino de vocabulário, itens essenciais para desenvolver tal habilidade". O ensino de gramática é secundário nas apostilas. A gramática serve como apoio para leitura. Os textos utilizados nas apostilas são retirados de revistas como News Week, Business Week, Time, The Economist, de interesse de adolescentes e que não envelhecem, ou seja, elas têm que ser atemporais. Como ele afirma:

eu escolho pro jovem de 17 anos. Não adianta eu falar sobre o desenvolvimento da África Sub-Saharan. Então tem que ser alguma coisa relacionada ao jovem incluindo drogas, coisas do dia-a-dia deles como sexo, computação, Internet e que seja da vivência deles.

O elaborador ressalta que com poucas aulas de língua inglesa nas grades das escolas, os professores que utilizam as apostilas não terão tempo de utilizar materiais complementares. Os programas dos vestibulares paulistas são consultados para o desenvolvimento do material didático, como afirma o professor. Tal qual os outros elaboradores de apostilas dessa investigação, documentos oficiais tais como PCNs, LDB dentre outros não são consultados, pois o objetivo

8 Na entrevista ele usa o termo " no mínimo ‘intermediate’ de língua inglesa”. 
maior do material é de preparar o aluno para exames de vestibulares. Interessante como poucos profissionais recorrem aos documentos oficiais!

O elaborador das apostilas do Colégio Objetivo pensa que os vestibulares são instrumentos tão poderosos de avaliação que eles se tornam um mecanismo de mudanças no ensino que o precede. Ele dá o exemplo da prova de redação em língua materna:

Sem dúvida [o exame de vestibular influencia o ensino que o precede]. Isso me reporta o caso da redação. Quando a Fuvest e outras universidades introduziram a redação alguns anos atrás foi um corre-corre no ensino médio para que a redação passasse a ter um valor maior. Havia escolas que nem sequer exigia a redação de seus alunos. MAS SEM DÚVIDA!!! VEM DE CIMA PARA BAIXO!!! MAS SEM DÚVIDA!!! SEM DÚVIDA.

Para o elaborador da apostila do Objetivo, o vestibular da UFPR em si não influencia seu trabalho, mas como a maioria dos vestibulares do país avalia interpretação de textos, podemos notar uma forte influência ou efeito retroativo dos vestibulares em seu material didático. Seu material é dirigido a um público que já teve acesso ao ensino de língua inglesa de bom nível, no ensino fundamental e médio, e que poderá aumentar seu vocabulário, conhecimento gramatical e desenvolver a leitura a partir de suas apostilas. Na verdade, após ter analisado a apostila, constatei que o ensino de gramática e vocabulário, apesar de sempre estarem relacionados com o tema do texto, continua sendo feito ao modo estruturalista, com esquemas de explicação gramatical, exercícios de múltipla-escolha e listas de vocabulário aos moldes da era psicométrica-estruturalista.

\subsubsection{As percepções dos alunos do Colégio DP}

Os alunos do terceirão do Colégio DP têm entre 16 e 19 anos de idade. Dos nove alunos regularmente matriculados no último ano do ensino médio, somente dois fazem curso pré-vestibular em outra instituição. Apesar de a maioria dos alunos afirmar ter tido instrução formal da língua inglesa desde o primeiro ano do ensino fundamental, quase todos não sentem que o inglês aprendido na escola garantirá uma boa nota na prova de inglês do vestibular da UFPR. Para poder ter um melhor desempenho na prova de inglês no vestibular e para se preparar para a carreira, metade dos alunos cursa a língua inglesa em institutos de línguas, além de estudar a disciplina do colégio por algumas horas toda semana - estuda com suas apostilas, leitura de textos de revistas e qual- 
quer outro material pertinente à interpretação de textos. Os alunos que não procuram por instrução da língua paralelamente à escola também não têm o hábito de estudar a disciplina do colégio como os alunos das escolas públicas. Nenhum deles trabalha e podemos constatar que somente uma minoria dos alunos está realmente comprometida em se preparar adequadamente para o vestibular. Apesar de os alunos terem consciência de que o conhecimento de uma língua estrangeira seja importante para o seu futuro profissional, a maioria não demonstra qualquer interesse em aprendê-la.

Os alunos obtêm informações sobre o exame do vestibular da UFPR através dos professores e do colégio, Internet, jornais e revistas. Metade dos alunos acredita que cursar a UFPR seja um fator importante para seu futuro profissional. A outra metade não anseia por uma instituição superior pública, pois têm garantida a entrada em qualquer uma das instituições superiores particulares.

Ao ser-lhe solicitada sua opinião sobre a prova de língua inglesa do vestibular da UFPR, a maioria disse que ela não é difícil. Somente dois deles admitem que ela seja muito difícil. Nas aulas, eles dedicam boa parte do tempo ao desenvolvimento da gramática da língua, o que contradiz o que a professora afirma fazer em sala: trabalho de interpretação de textos e ensino de vocabulário. Alguns alunos ressaltam, porém, que a partir da mudança da prova para o enfoque em interpretação de texto, a professora começou a aplicar duas provas de interpretação de textos duas vezes ao mês. Os alunos também asseveram que avaliar a interpretação de textos foge do que eles aprenderam no ensino fundamental e médio. A grande maioria não se sente capacitada a prestar tal prova, por não ter trabalhado com a leitura adequadamente desde o fundamental. E como a grande maioria disse não conhecer a prova (apesar de trabalhar com exames anteriores em sala de aula!), os alunos não conseguiram opinar se o exame contempla os conteúdos e capacidades necessárias para quem pretende usar o inglês na universidade. Somente duas alunas pensam que o exame pode ser um mecanismo eficiente de mudanças no ensino de inglês nas escolas de ensino médio. Uma delas afirma que o exame "poderia sim ser um mecanismo de mudanças, mas por enquanto eu acho que não interfere em minha escola".

As expectativas que os alunos têm em relação ao ensino de inglês no ensino médio parece não ser a mesma que a professora traçou para eles. Há uma clara divergência entre a expectativa do professor e a dos alunos. Apesar de a professora afirmar que prepara os alunos para o vestibular da UFPR, os alunos não se acham preparados para enfrentar tal exame, por achar que o nível do exame está aquém de suas capacidades. Visão diferente dos alunos do 
Colégio DB, mas igual aos das escolas públicas, com a diferença que a professora do Colégio DP pensa que suas aulas vão preparar seus alunos para o exame e as professoras da escola pública têm consciência de que suas aulas não os preparam para o exame.

O Colégio DP tem os mesmos objetivos e segue o mesmo comportamento do Colégio DB, com poucas diferenças. Percebemos que as orientadoras e professora têm o mesmo objetivo de aprovar os alunos na UFPR. Porém, notamos que as orientadoras não participam diretamente no processo de procura de informação e análise de vestibulares anteriores, como faz o diretor do Colégio DB. É dever do professor, e não da escola, procurar informações e desenvolver um planejamento adequado, mesmo lhe tendo sido imposta uma apostila do Estado de São Paulo cujo o foco está nos vestibulares paulistas. Uma outra diferença está na atitude dos alunos. Nesse colégio, não é objetivo de todos fazer o vestibular da UFPR. Muitos preferem entrar em instituições superiores particulares, por oferecerem exames que exigem menos horas de estudo, pois são menos concorridos e mais fáceis de passar.

Tanto as orientadoras quanto a professora e elaboradora da apostila compartilham da opinião de que o exame de inglês do vestibular da UFPR não é difícil. Os alunos, por sua vez, disseram que a prova não é difícil, mas que não se sentem capacitados para fazê-la, pois não trabalharam a leitura adequadamente desde o ensino fundamental. As orientadoras afirmaram que o exame do vestibular poderia ser um mecanismo eficiente de mudanças do ensino de inglês no ensino médio se ele fosse "democrático" e "se partisse de uma discussão entre elaboradores do exame e escolas". A professora, ao contrário das orientadoras, disse que "querendo ou não você acaba mudando e se adaptando para o vestibular e que a força do exame está longe do alcance do professor ou da escola”. Sua visão do exame é determinista e inexorável. Como a professora, o elaborador da apostila acha que os vestibulares são poderosos instrumentos que causam mudanças no ensino que o precede mesmo que ele concorde ou não com isso. A maioria dos alunos desse cenário não acha que o exame influencia o ensino de inglês em sua escola, discurso contraditório com o discurso das orientadoras e professora que afirmam que o objetivo da escola é direcionar seu ensino médio para os vestibulares do país e em específico para o da UFPR.

Portanto, podemos concluir que o exame de inglês do vestibular da UFPR é percebido como exercendo uma influência no ensino de língua estrangeira no ensino médio do Colégio DP. O efeito retroativo do exame é sentido no discurso e ações das orientadoras e professora, bem como nos dos alunos e elaborador de material didático. $\mathrm{O}$ exame influencia positivamente na estipulação de objeti- 
vos claros de ensino e materiais didáticos; quando instiga a professora a atualizar-se e adequar-se às novas exigências do exame; quando faz com que o aluno, que tem real intenção de ser aprovado, estudar mais; quando direciona o ensino de língua inglesa, bem como os materiais didáticos, para a leitura. É interessante observar que na realização do planejamento, nenhum documento oficial do MEC ou da Secretaria Estadual da Educação é utilizado para estabelecer objetivos de ensino.

Porém, o exame influencia negativamente quando exige, muitas vezes, somente questões do tipo reconstituição de informações. Isso leva a professora a negligenciar o trabalho com tipos de questões de predominância argumentativa, descritos por Nery (2003) e Nery e Cherem (1993). Outro fator limitador é que o exame restringe-se a leitura, o que pode provocar estreitamento de currículo, pois outras habilidades como a fala, a escrita e a compreensão auditiva são desconsideradas. Devido ao fato de, esporadicamente, aparecerem itens isolados da língua, o exame ainda pode levar o professor ao ensino da língua fragmentada. A professora privilegia o ensino de gramática e vocabulário de maneira descontextualizada, utilizando muitos exercícios de itens isolados, como o cloze e a tradução. Notamos que nas aulas, raramente ela mostrou a relação de pontos gramaticais e vocabulário com o processo de construção de sentido dos textos. Além disso, a maneira como alguns alunos estudam a língua inglesa - focando os estudos na gramática e vocabulário com itens isolados mostra que suas concepções de aprendizagem também são tradicionais.

Nos dois cenários das escolas particulares, notamos que o exame de inglês do vestibular da UFPR tem uma forte influência no ensino médio desde o planejamento das ementas das aulas até na escolha dos materiais didáticos usados nas escolas. Os diretores/orientadores, professores e elaboradores de apostilas dedicam boa parte de seu tempo buscando informações sobre o exame e, como as escolas podem tornar seu ensino mais eficiente para que seus alunos sejam bem sucedidos no vestibular da UFPR. Por não conhecerem bem as concepções de língua, de leitura e de avaliação que embasam o exame e nem as concepções correntes de ensino e de avaliação que poderiam tornar o exame um bom instrumento potencial para o efeito retroativo positivo, algumas práticas mais tradicionais ainda são observadas nas aulas dos dois professores. Se eles conhecessem a fundo a filosofia que embasa o exame bem como as novas tendências do ensino de LE/leitura, eles poderiam preparar seus alunos para tornarem-se leitores (e porque não falantes também) proficientes e o sucesso no vestibular da UFPR seria apenas uma conseqüência natural do bom ensino/aprendizado. Porém, o empenho de todos os sujeitos desses cenários é 
bem grande para preparar seus alunos para o ensino superior, empenho este que não se percebe nos cenários das escolas públicas.

\subsection{CURSO PRÉ-VESTIBULAR PARA AFRODESCENDENTES}

O curso pré-vestibular para afrodescendentes recebe alunos negros, mulatos e pardos, oriundos de escolas públicas de periferia. O conhecimento de inglês é muito pequeno devido à precariedade do curso de inglês nas escolas públicas - onde $100 \%$ desses alunos estudaram - e por essa razão a grande maioria - 90\% - opta por fazer a prova de espanhol, ao invés do inglês, por achar a transparência da língua espanhola uma aliada.

\subsubsection{As percepções da diretora do curso pré-vestibular KN}

Assim como as orientadoras do Colégio DP, os profissionais do KN conseguem informações sobre o vestibular da UFPR através do site da universidade e da mídia. O exame da Federal, a questão dos afrodescendentes e ações educativas também foram assunto de discussão em reunião entre as novas universidades particulares da cidade e representantes de todo o Estado ligado à escola pública, ensino fundamental e médio.

Todo esse esforço para conseguir informações do vestibular para seu curso pré-vestibular é despendido pelo fato de a diretora achar que o papel do vestibular da UFPR, na vida de seus alunos, é de extrema importância. Para ela, o acesso à universidade pública é "uma forma de inclusão social e uma questão de direito e cidadania e não um favor ou obrigação".

Porém, pelo passado escolar precário em escolas públicas, o desempenho dos alunos nas provas de línguas estrangeiras é muito baixo. Para a grande parte dos alunos, a prova de língua inglesa é extremamente difícil.

Ao ser questionada sobre se a prova de língua inglesa do exame de vestibular da UFPR contempla os conteúdos e capacidades necessárias para quem pretende usar o inglês na universidade, ela afirmou que se o candidato for bem na prova, que sabidamente é muito difícil, ele deverá ser capaz de utilizar a língua como um instrumento para leitura de textos acadêmicos.

Apesar de achar que os candidatos aprovados no exame possam ter um bom desempenho na universidade, ela não acredita que o vestibular possa ser um mecanismo eficiente de mudanças no ensino de inglês nas escolas de ensino médio. A diretora pensa que o vestibular deveria ser extinto e substituído por uma outra forma de seleção. 
Eu acho que tinha que haver um outro acesso à entrada na universidade. Não através do vestibular. Poderia talvez investir no ensino fundamental e médio ao ponto desse aluno ser gradativamente sendo incluido nessa universidade. Acho que é ideologia minha, né? Mas enfim, eu acho que é...porque eu acho que o vestibular é uma exclusão tão grande. Ter acesso à universidade através desse tipo de vestibular que tá aí...

Talvez a diretora gostaria que fosse implantado no Paraná algum sistema de avaliação similar ao PAS - Programa de Avaliação Seriada da Universidade de Brasília. ${ }^{9}$ Porém, na verdade, a luta tem que ser por um ensino fundamental e médio de qualidade para que essa população possa competir em igualdade com os alunos/candidatos brancos e não extinguir o exame, que pode servir como balizador do ensino que o precede. Sua visão vem de um sentimento que seus alunos têm demonstrado em relação ao vestibular da UFPR. Ela afirma que "a maioria dos alunos se sentem muito distantes de toda exigência e até acham que não vão conseguir. Tudo é muito difícil e por esse motivo um grupo bastante desanimado. Porém, ao contrário que se esperaria, muitos, a maioria ainda quer tentar'. Esse desânimo é explicado pelos dados dos candidatos do ano anterior: embora 100 alunos tenham concluído o curso pré-vestibular, somente três foram aprovados na UFPR.

Remando contra essa maré desfavorável, os professores continuam se adaptando às novas tendências do vestibular. Ao comentar a mudança que o professor de inglês fez em sala de aula do cursinho por causa do exame, ela diz:

[Tomando a fala do professor de inglês] 'Eu não preciso mais ensinar só... eu posso sair da gramática. Não preciso ficar muito mais na gramática porque lá no vestibular não é cobrado mais a gramática...' Foi uma mudança de atitude, de metodologia, conteúdos que eles [os professores do curso] escolhem para sala de aula também. Eu acho que até exige um pouco mais de pesquisa, mudança de organização interna, Exige pesquisa...

9 O Programa de Avaliação Seriada -PAS possui um objetivo peculiar, que é o de "selecionar os futuros estudantes universitários de modo gradual e sistemático, não como o produto de um único exame seletivo episódico, mas como a culminância de um processo que se desenvolve ao longo do ensino médio". Mais informações no http://www.cespe.unb.br/pas/ oquepas/oquepas2.htm 
Além das mudanças percebidas em sala de aula, os professores também tomaram o cuidado de preparar uma avaliação diferenciada para fazer com que seus alunos ficassem familiarizados com o formato do exame.

Toda essa preocupação em se modernizar para o exame do vestibular se vê através do esforço grande que os professores têm em ajudar os alunos. É visível o carinho e preocupação 'paterna/materna' de muitos professores com seus alunos.

Por último, foi perguntado se ela achava que os objetivos dos PCNs convergiam com os objetivos do vestibular da UFPR. Ela foi bem enfática ao dizer que há uma distância grande entre os dois objetivos. Ela questionou a validade dos PCNs ao dizer:

Não. Não falo essa linguagem. Não dá pra entender o PCN nacional. Por conta das realidades. A forma do encaminhamento dos conteúdos. Como se fazem os planejamentos. A preocupação básica ainda é a questão da alfabetização. Dá condição de escola pro aluno. Os PCNs não tem um projeto universitário para os alunos.

Eu fico na dúvida. Eu acho que não. Quem foram os idealizadores e quem fez a redação final dos PCNs? São aqueles 'PhDeuses'? Eles (do vestibular) falam uma linguagem tão distante. Os objetivos lançados pro vestibular estão muito longe das escolas públicas. Longe do chão da escola. Se pensar na formação, no ensino/aprendizagem, você tem que pensar no cotidiano da escola."

A diretora do KN é ciente de que os PCNs não objetivam a preparação dos alunos para a vida acadêmica e portanto, não contemplam instruções necessárias para que o aluno prosseguir os estudos em nível superior. Ela também é ciente dos problemas estruturais da escola pública que impede aos alunos qualquer projeto de vida nesse sentido. O vestibular da UFPR é a razão da existência do projeto KN, uma vez que o curso surgiu para ajudar os afro-descendentes entrarem na UFPR e, portanto, o efeito retroativo é sentido nas falas e ações dos idealizadores do projeto.

\subsubsection{As percepções do professor do curso pré-vestibular KN}

O professor do curso KN, negro também, define o perfil de seus alunos como classe C, D e E. São todos da periferia, e, geralmente, possuem uma série de problemas familiares: desemprego de pai, pais doentes, pais drogados, falta de alimentação adequada, renda per capita não mais que dois salários mínimos por família, dentre outros. 
Segundo o professor, a língua inglesa, para essa comunidade, é um tema muito distante, pois eles não necessitam da língua como um instrumento para o trabalho. No curso KN, poucos alunos optam por fazer a prova de língua inglesa por acharem-na muito difícil, e escolhem a prova de língua espanhola. $\mathrm{O}$ professor também acha a prova difícil e diz que a priori uma pessoa que vai bem na prova deveria ter um conhecimento bom da língua e utilizá-la com facilidade na graduação. Porém, ele conhece várias pessoas, que ao fazer uma prova de proficiência de inglês para a pós-graduação, não são bem sucedidas. Isso demonstra que "há algo de errado com o exame". Esse foi o mesmo discurso da orientadora do Colégio DP. Na verdade, muitos alunos da pós-graduação da UFPR não foram, necessariamente, alunos da graduação da própria instituição. Além disso, dos alunos que fizeram a graduação na instituição, não fizeram, necessariamente, vestibular depois de 1995, quando a prova mudou o enfoque para interpretação de textos. Um terceiro argumento é que há alunos que tiraram notas baixas no exame de língua estrangeira, mas assim mesmo foram classificados para os cursos de baixa procura.

A instituição ACNAP, no qual o projeto KN nasceu, orienta seus professores a trabalharem questões da cultura negra, uma vez que a auto-estima deles geralmente é muito baixa. Como alerta o professor:

Os próprios alunos não acreditam que eles possam passar na Federal, por conta da situação de hoje que.....pra eles só passa no vestibular se fizer cursinho bom. A escola pública não dá conta. Então o que eu tenho dito pra eles: 'Não se iludam em só fazer a Federal'. Eu paguei uma particular...eu fiquei muito satisfeito com isso, porque eu fui aprender o que queria após a graduação (ri)....

O próprio professor, em seu discurso, mostra o desânimo: "não se iludam em só fazer a Federal". Para muitos alunos do KN, entrar em uma instituição Federal é uma meta inatingível. Mas mesmo assim, como o ensino superior é uma das únicas maneiras de conseguirem ascensão social, eles freqüentam um ano de curso pré-vestibular para se prepararem para o exame. A grande maioria dos alunos acha a prova de língua inglesa muito difícil e tem muito medo dela. Como a diretora, também o professor afirma que tal medo se deve ao fato dos alunos terem um conhecimento muito limitado da língua e, no cursinho, ao invés de reverem os conteúdos, eles têm que aprendê-los.

Nós temos um problema: muitos deles têm uma bagagem do inglês muito limitada, Então enquanto muitos alunos nos cursinhos estão revendo conteúdo, aqui eles estão aprendendo o conteúdo. Então 
nós temos que trabalhar e prepará-lo pra depois trabalhar a apostila. Então isso demanda mais tempo e você perde mais tempo para se aproximar do objetivo.

Esse problema que vivenciam os alunos do $\mathrm{KN}$ é realmente um fator limitador, pois como os alunos nada ou pouco sabem da língua, interpretar os textos do vestibular da UFPR é um objetivo inatingível, a curto prazo pelo menos. Porém, se o professor conhecesse as novas tendências no ensino de leitura, ele conseguiria trabalhar a habilidade, gradativamente, a partir de um nível mais elementar até chegar a um mais avançado de língua e leitura concomitantemente. É viável construir um repertório lingüístico a partir dos próprios textos.

O professor do KN enfrenta um outro tipo de limitação: a falta de informação. Os professores desse cursinho não têm acesso à informação de outros colegas de outros cursinhos e sabem de alguma novidade através da mídia e de uma professora da Federal, que é simpatizante do movimento.

A falta de informação fez com que o professor centrasse suas aulas na gramática ao invés da interpretação de textos no começo do curso. No início das minhas observações de aula, ele trazia para aulas questões antigas de outros vestibulares que eram de itens gramaticais isolados. Ao observar as aulas, passei a dar algumas sugestões e o professor começou a estudar os vestibulares mais recentes da UFPR, e a partir daí, o foco da aula passou a ser o ensino de vocabulário e interpretação de textos. Ele comenta que tem lido tudo o que é possível no que se refere aos exames, aos textos e à interpretação de textos, para poder oferecer um ensino mais dirigido. Simulados do exame da Federal são, freqüentemente, utilizados para que seus alunos consigam se habituar com o formato da prova, além de verificar o progresso deles e as reais chances de passar no vestibular. Ele comenta:

Porque eu tinha apostilas do Positivo.... eles doaram....eu estou sendo maldoso, mas eles doaram porque estavam ultrapassados ... mas não deixaram de ser úteis. Porque não tem nenhum livro bom o tempo todo. Então a gente tem que ser versátil, mesmo que seja tradicionais... ênfase na gramática deve ser aproveitados... mas com essa visão: é o texto que vai permear.

Para o professor, os textos do exame são interessantes. Porém a quantidade de informação que o aluno tem que dominar é "um absurdo". Aliás, é o mesmo comentário feito pela professora do Colégio DP. Ele também acha que a avaliação indireta da gramática é interessante uma vez que o objetivo final é 
a interpretação do texto. Como o vestibular avalia compreensão de leitura, o professor teve que repensar suas aulas.

Ao ser indagado se ele acha que o exame pode ser um mecanismo eficiente de mudanças no ensino de inglês nas escolas de ensino médio, o professor respondeu que se o objetivo é ensinar seu aluno a pensar, a interpretar e entender, então, o vestibular pode influenciar com bom resultado. Mudar o enfoque de aula dos alunos para que eles cheguem no vestibular mais preparados pode corrigir erros do ensino médio.

Porém, o professor, que também trabalha na rede pública, adverte que a realidade da escola pública é bem diferente do que seria uma boa escola ou pelo menos razoável. O professor chama a atenção para os problemas estruturais do sistema público. Ele explica:

O processo da grade é muito ingrata. De $5^{a}$ à $8^{a}$ série os alunos têm duas aulas por semana. Quando chega no ensino médio, esbarra no problema...eles só vão ter aula de inglês no terceiro ano. Quando o professor vai... Quando a escola tem um professor.. Então é um crime que eles cometem. Como é que eles querem um bom aluno que leia, e um bom professor de inglês, se eles não têm meios próprios para bancar os cursos? E a escola não dá conta de formar um professor. A escola não dá conta de formar um professor nem de fazer uma grade bem feita. Um outro aspecto que eu acho relevante é que tem um aluno que opta por espanhol porque ele acha mais fácil. O aluno deveria escolher na $5^{a}$ série se ele quer fazer inglês ou espanhol. Ele não tem espanhol no curso e acaba fazendo espanhol no vestibular. Na escola particular tem, mas no Estado não temos concurso para professores de espanhol. Não tem uma coisa errada? Tem que ampliar o número de aulas. Olha que incoerência: eles têm cinco aulas de português semanais desde a $5^{a}$ no fundamental e o término do médio. O que que ocorre hoje? Não se conseguem completar as vagas de juizes sabe o porquê? Boa parte dos advogados, desse derrame de advogados que existem por ai, não redigem bem. Não passa na prova de redação. Então porque tanta aula de português se ela não atinge as expectativas? Que incoerência!

O professor teceu vários comentários interessantes. Primeiro, ele aponta a falha - já apontada nesse estudo - da incoerência e inconsistência do ensino de inglês desde a $5^{\mathrm{a}}$ série até o $3^{\circ}$ ano do ensino médio. A falta de um planeja- 
mento de conteúdos e seqüência de conteúdos no fundamental, e do fundamental para médio impede qualquer trabalho sério e bem elaborado (ver item 4.1.1). Um outro ponto interessante que ele tocou foi a do aluno que nunca estudou espanhol na escola e opta pela língua no vestibular por não ter adquirido um conhecimento adequado para enfrentar o inglês no exame. Porém, o exame de espanhol pode ser visto como um 'mito da facilidade', pois o exame da língua, apesar de ser românica, não garante ao candidato um melhor desempenho se não for bem preparado. A terceira crítica bastante pertinente é que muitas escolas do Estado não oferecem a disciplina de inglês nos $1^{\circ}$ e $2^{\circ}$ anos do ensino médio. O professor também é bastante coerente quando diz que não há professores suficientes de inglês para as aulas, e muitos que estão na escola não possuem uma competência lingüística adequada para darem aulas. E a última crítica é a mais astuta: a escola oferece em língua portuguesa um grande número de aulas, mas mesmo assim os alunos são incapazes de aprender a ler e escrever eficazmente, ou seja, o problema não é somente uma questão quantitativa (número de aulas da disciplina), mas também qualitativo: as aulas têm que ser de qualidade para que os alunos possam aprender.

Como os membros da ACNAP têm consciência da realidade escolar vivida pelos seus alunos, eles têm uma grande preocupação em fazer um trabalho bem feito no curso KN. É cobrado do professor o máximo de empenho com sua disciplina, e o trabalho com a auto-estima dos alunos para que eles não desistam do curso. O lema adotado é 'Nós vamos fazer a diferença!" Em 2003, quatro alunos (entre 200) foram aprovados na Federal e quatro na PUC-PR. Em 2004, em virtude das cotas, o número subiu para 20. Apesar do imenso empenho de toda a equipe de professores e diretora do curso, poucos alunos/candidatos conseguem ingressar na UFPR. Além disso, dos que ingressam, a grande maioria são aprovados em cursos de menor prestígio como Letras, Geografia e Pedagogia. A luta desse grupo organizado deveria seguir, paralelamente, em direção a uma educação fundamental e média de qualidade para, no futuro, garantir que seus membros consigam competir, com o grupo branco dominante das Classes A e B, em grau de igualdade por uma vaga na universidade pública.

\subsubsection{As aulas do professor do curso $\mathrm{KN}$}

Para preparar seus alunos para o vestibular da UFPR, a ACNAP utiliza as apostilas do Colégio Positivo. O colégio particular doou ao grupo KN suas apostilas antigas que já não são mais utilizadas pela instituição. Por ser um material mais antigo, os professores utilizam muitos materiais complementares. 
Diferentemente dos alunos da Escola LC e dos Colégios DP e DB, os alunos do KN são motivados e interativos em sala de aula. Mais parece uma reunião de amigos do que um ambiente formal de curso. Todos, num total de 20 alunos, ao chegarem se cumprimentam, inclusive se a aula estiver em andamento. Sem dúvida alguma, é um ambiente agradável de aula. Todos são bem descontraídos, falantes e participativos. No começo do curso, o professor estava totalmente voltado ao ensino de gramática e tradução de vocabulário aos moldes do Método Gramática-Tradução. As explicações eram dadas na lousa, e os exercícios propostos de itens isolados (Anexo E.1). Após numerosas aulas de gramática e tradução, o professor começou a utilizar o material que o Colégio Positivo havia doado.

As páginas 1 e 2 (Anexo E.2) nos mostram como o vocabulário era trabalhado: listas de palavras sobre um tema para serem traduzidas. As atividades também eram bem estruturalistas.

Os textos da apostila são simples, não autênticos, com ênfase no vocabulário (Anexo E.3, p. 1). A interpretação dos textos limita-se a questões de reconstituição de informações pontuais e lineares. Após minha interferência nas aulas ${ }^{10}$ o professor começou a trazer textos autênticos e todos eram relacionados com temas relevantes para a comunidade negra, tais como pobreza, racismo, saúde e outras questões culturais importantes para o grupo (Anexo E.3, p. 3 e 4). A preocupação de formação crítica dos alunos e da comunidade é facilmente perceptível nas atividades propostas pelo professor e nas discussões que os textos suscitavam. O texto da Etiópia (Anexo E.3, p. 3) mostra um país africano com suas dificuldades. Tal texto foi usado em um simulado, e após as correções houve um debate sobre a condição negra no continente africano e no Brasil. Apesar do tema ser bem interessante e instigante, os exercícios são estruturalistas, como múltipla-escola e preenchimento de lacunas. O outro texto foi sobre AIDS e mostrava em quais países a doença avançava (Anexo E.3, p. 4). Os alunos falaram sobre o texto e sobre o grande número de africanos contaminados. Tal texto suscitou um debate bem interessante, que foi conduzido na língua materna. As aulas de leitura, muitas vezes, viravam um pretexto para discussões e debates de temas instigantes.

10 Até eu começar a observar as aulas do professor de inglês, as aulas eram de explicação gramatical com exercícios de itens isolados. Ao perceber que o professor não trabalhava textos, eu interferi e o alertei para o fato de que o exame cobrava interpretação de textos e que as aulas deveriam ser mais focadas em leitura. 


\section{Uma aula de compreensão de texto}

Na quinta semana de observação de aula o professor trabalhou com um texto da apostila sobre Golfinhos (Anexo E.3, p. 3).

For many years scientists believed that the chimpanzee was the most intelligent animal in the world. Recently they have learned that the dolphins are very clever animals too. Perhaps they are more intelligent than chimpanzees.

Many people think that dolphins are fish, but it is not true. Dolphins are different from fish in many important ways. They are mammals. They are warm-blooded, and they cannot stay under water all the time, like fish. They breathe air. They must come to surface of the water and take in air every few minutes.

Dolphins live in groups, or "schools". Schools of dolphins travel and catch fish together, and they also use a kind of language. Scientists do not understand the language of dolphins, but they know that these animals talk to each other and send messages under water.

Dolphins are very friendly to human beings, and they are helpful, too. In the past few years, scientists have taught dolphins to play games and to help man in many ways. In some ways dolphins are like dogs, but they are a lot more intelligent. Perhaps they will soon become the most useful animals in the world.

O professor começou a aula lendo o texto em voz alta para todos os alunos. Ele falou sobre a figura (ver Anexo E.3, p. 3) dos golfinhos. Ele voltou no início do texto traduzindo algumas palavra que julgava difíceis. Ele pára na expressão "each other" e escreve no quadro "Jesus Said: Love each other." E traduz o significado. Ele repete a estratégia com outras palavras como "breathe", "mammals" dentre outras. Um aluno pergunta o significado de "taught". O professor escreveu no quadro "teach, taught, taught" e traduziu o significado. A seguir ele foi para os exercícios. Ele lia as alternativas, traduzindo-as e, depois, perguntava aos alunos se elas eram verdadeiras ou falsas de acordo com o texto. Exemplo de um exercício:

06.01. (PUC - PR) Which is the only wrong alternative?

a) Dolphins are different from fish in many ways.

b) Dolphins cannot stay under water all the time.

c) Dolphins must come to surface of the water and take air only for a few minutes.

d) Dolphins are clever, helpful, friendly and useful.

e) Dolphins live in groups. 
Apesar dos textos que o professor trazia para as aulas serem interessantes, os alunos não possuíam conhecimento mínimo de inglês para que eles pudessem sozinhos fazer uma interpretação adequada. As aulas de gramática e vocabulário eram bem centradas nas estruturas e não davam embasamento necessário para que eles pudessem se tornar leitores independentes. Na maior parte do tempo, o professor acabava traduzindo os textos para o português para que os alunos pudessem entendê-lo, e isso impedia que eles pudessem desenvolver estratégias de leitura para avançarem sozinhos.

\subsubsection{A apostila do curso pré-vestibular KN e as percepções de seu elaborador}

A elaboradora do material didático do Colégio Positivo desenvolve material há 20 anos. A graduação e especialização foram concluídas na Universidade Federal do Paraná. Ela leciona a língua inglesa há 25 anos, sendo que 19 em cursos pré-vestibulares. Ela já trabalhou em diversas escolas renomadas da cidade, como Colégio Madalena Sofia, Bardal, Expoente, Decisivo e Apogeu. Atualmente, atua no Colégio Positivo como professora e elaboradora de apostilas. A professora participa dos encontros, quando oferecidos, sobre as provas de línguas estrangeiras que o Departamento de Letras da UFPR abre aos professores do ensino médio e cursos pré-vestibulares. Ela, ao contrário dos professores da escola pública e da professora do Colégio DP, sempre foi informada sobre os encontros.

A professora tem vários tipos de alunos em mente ao escrever seu material: desde o aluno que nada sabe até o mais proficiente. Portanto, existe uma preocupação em "mesclar a apostila colocando conteúdos mais elementares até chegar aos mais difíceis". Isso se deve ao fato de que muitos alunos vêm do interior do Estado e têm pouco conhecimento lingüístico, ao passo que os alunos da capital já terem cursado, muitas vezes, institutos de línguas. Como as apostilas da elaboradora são comercializadas no Estado inteiro, ela escreve o material, tendo em mente profissionais que tenham um bom conhecimento lingüístico, pelo menos o mesmo conhecimento exigido para ser bem sucedido no vestibular.

A professora/elaboradora salienta que, no geral, os alunos não dão a importância devida à língua estrangeira, o que é uma reclamação unânime entre todos os professores que foram entrevistados nesta investigação. Os alunos começam a perceber a necessidade do conhecimento da língua quando vão mal nos simulados no segundo semestre do terceirão. A partir do segundo semestre, há uma corrida aos plantões de dúvida e aos professores de língua inglesa. 
Ao escrever as apostilas, o objetivo primordial do material é de preparar os alunos para os vestibulares da cidade, principalmente da UFPR. Para atingir tal objetivo, o programa do vestibular, assim como os últimos exames são utilizados para direcionar o que é escrito. Os profissionais da mesma área de outras escolas estão sempre tendo bate-papos não oficiais sobre o vestibular e suas peculiaridades. Documentos oficiais como PCN, LDB dentre outros nunca são consultados. Tal qual os professores dos Colégios DB, DP e o curso KN, essa professora/elaboradora não consegue ver uma ligação lógica entre os documentos oficiais e o programa do vestibular da UFPR. Ao meu ver, esses profissionais nem sequer consultam os documentos oficiais, pois os PCNs apresentam incoerências de objetivos propostos para o ensino médio, além de "deixar de ser 'apenas' preparatório para o ensino superior" (se é que já teve tal nobre objetivo nos últimos 35 anos.) (ver item 4. 1).

As apostilas são divididas em duas partes: uma que focaliza a "gramática aplicada" - dada por um professor, e a outra interpretação de texto - dado por outro. As aulas de gramática e interpretação estão em relação de complementaridade, segundo a professora/elaboradora (Ela é professora de um curso prévestibular famoso na cidade). Os textos utilizados nas apostilas são de revistas e jornais como Time, News Week, Speak Up e sobre assuntos modernos como o mundo físico, o mundo ambiental, ecologia, catástrofes, dentre outros. O vocabulário destes temas é bastante trabalhado. As apostilas têm tanta informação que o professor não tem tempo para materiais complementares. Porém, como nas outras apostilas investigadas neste estudo, o que acontece, de fato, é que a apostila fica fragmentada em duas seções distintas: uma seção de gramática descontextualizada e uma seção de textos com vocabulário, geralmente para serem traduzidos. Apesar de focar o trabalho em leitura, o trabalho estruturalista com a língua ainda impera.

Todo o conteúdo é trabalhado, segundo a professora, para preparar os alunos para uma prova de língua inglesa na qual os textos variam muito em grau de dificuldade. Em alguns anos, os textos são muito difíceis para quem está saindo do ensino médio. Em outros anos, os textos já são mais adequados ao nível dos candidatos. A mesma reclamação fizeram os professores dos Colégios DB, DP e do curso KN assim como os elaboradores das apostilas do Colégio DB. Para a elaboradora, não há uma padronização de tipos e graus de dificuldade de textos e esse fato dificulta e muito no desenvolvimento de material didático. Observação bastante perspicaz da elaboradora, pois se observarmos os vestibulares de 2000 a 2006 (Anexo A.4. a A. 10) veremos que alguns textos realmente apresentam um grau de dificuldade maior - em termos de vocabulário 
e estrutura - do que outros. Apesar de as provas não terem um grau de dificuldade homogêneo, a professora acha que o exame avalia seus candidatos adequadamente, pois os candidatos que são bem sucedidos na prova, geralmente conseguem ler qualquer texto acadêmico. Ela lamenta, porém, que a gramática não seja mais cobrada nos exames. Ela reclama: "eu acho que o exame deveria ser mesclado e não só texto, texto, texto." Mais uma vez, vemos visões estruturalistas cristalizadas na fala da professora, bem como no material elaborado por ela (ver listas de vocabulário para ser traduzido para o português e exercícios de itens isolados nas páginas 1 e 2, no Anexo E.2). Quando avaliamos a leitura, indiretamente avaliamos também a gramática da língua.

A elaboradora assevera que o exame de vestibular é um mecanismo eficiente de mudanças no ensino de inglês nas escolas do ensino médio. Ela afirma que todo seu trabalho gira em torno do vestibular e que tanto o conteúdo, seleção das atividades e seqüência de conteúdos são adequados nas apostilas para preparar seus alunos para o exame. Um outro exemplo de influência do exame no ensino que o precede é a adequação do material para o formato de avaliação que o vestibular utiliza:

Se ele [o vestibular da UFPR] mudar, vai mudar tudo. Vai mudar até o tipo de questão. A gente tem que fazer um outro material para ir de [sic] encontro com que eles querem. Vai ter que mudar. Por exemplo: se tem questão de somatória e com a mudança não ter questão de somatória, nós vamos ter que mudar para não nos perder.

Podemos perceber que o exame de inglês do vestibular da UFPR provoca um efeito retroativo forte no conteúdo da apostila, uma vez que focaliza a leitura. Entretanto, não conseguiu influenciar o ensino da língua que ainda se dá de uma maneira estruturalista aos moldes do Método Gramática-Tradução. O fato da gramática não ser avaliada explicitamente sinaliza para esses professores e elaboradores de apostilas que a gramática não é importante no exame, uma vez que desconhecem o que é leitura e o que é ensinar a ler. O que falta para eles é, primeiramente, conhecer concepções atuais de leitura para, posteriormente, conseguir relacionar a gramática da língua com o processo de construção de sentido de um texto.

\subsubsection{As percepções dos alunos do curso pré-vestibular KN}

Os alunos que freqüentam o curso têm entre 17 a 34 anos de idade. Todos são negros ou mulatos de baixa renda. Metade dos alunos trabalha de $30 \mathrm{a}$ 
40 horas semanais. Esses alunos procuraram o KN por ser gratuito e também pelo trabalho que o grupo faz no sentido de conscientização da cultura negra. O conhecimento de língua inglesa que eles têm é básico e aprendido desde a $5^{\mathrm{a}}$ série do ensino fundamental. O nível de conhecimento da língua é bem fraco. Eles têm consciência de que a instrução obtida na escola pública foi tão precária que seus esforços para passarem no vestibular da UFPR têm que ser multiplicados. Duas alunas lamentam:

Na escola pública você começa a estudar o inglês a partir da $5^{a}$ série, sendo que a escola particular começa desde o jardim. No cursinho, nós temos que tirar um atraso imenso para podermos ir bem na prova.

O inglês que vemos no colégio é sempre o mesmo desde a $8^{a}$ série até o $3^{\circ}$ ano do ensino médio (o verbo to be), e quando chegamos em cursinho pré-vestibular que exige muito mais, acabamos não aprendendo nada.

Muitos alunos sabem que para poderem melhorar seus escores no exame, deveriam ter mais aulas por semana. Por essa razão, a grande maioria estuda a língua pelo menos uma hora semanal, em casa. Eles também acham que o inglês aprendido no cursinho irá ajudá-los nos cursos superiores que eles venham a fazer. Para os alunos que optaram em fazer a prova de língua inglesa no vestibular, o idioma é importante para suas vidas profissionais, mas tal sentimento não é compartilhado por toda comunidade, como explica um aluno:

Bem, moro na periferia.. Minha comunidade já se esforça em aprender o português e quer passar longe do inglês. Eu acho que sou a diferença ou a minoria. Para mim, o inglês é necessário para todos. Pena que poucos pensam assim.

A fala do aluno ilustra que, para essa comunidade, o inglês não é um símbolo de status social e a maioria dá pouca importância à disciplina. Para tentar reverter esse quadro, o professor de inglês convida palestrantes negros, falantes da língua inglesa, para falarem sobre a condição negra no mundo e a importância deles se unirem e conversarem enquanto um grupo. Assim mesmo, muitos alunos continuam achando que eles não devem gastar muito tempo para aprender língua inglesa. Por esse motivo, eles não procuram especificamente informações sobre a prova de língua inglesa do vestibular. Eles as obtêm através da mídia e dos professores que trabalham no projeto $\mathrm{KN}$ - um contrassenso, pois as aulas são dadas dentro dos estabelecimentos da própria UFPR, 
mas não conseguem as informações. Para esses alunos, ingressar na UFPR é muito importante.

Eles afirmam:

"É a maneira de conseguir realizar meu sonho e ter um futuro garantido e respeitado [ênfase minha]."

"A oportunidade de cursar uma faculdade."

"É uma proposta para desenvolvimento intelectual e financeiro."

"Importantíssimo, pois o curso que vou tentar é muito caro em universidades particulares."

"Formar cidadãos bons nessa sociedade maligna em que vivemos."

Portanto, para a maioria dessa comunidade, o sucesso no vestibular significa um caminho para profissionalização qualificada, e assim, ascensão social e respeito.

Também a maioria dos alunos acha a prova de língua inglesa da UFPR difícil e concentra seus estudos na interpretação de textos e no aprendizado de vocabulário. Tanto os alunos quanto o professor de inglês do curso começaram a mudar seus hábitos de estudo/ensino quando foram por mim alertados da necessidade de desenvolver a capacidade de interpretar textos. O professor aumentou bastante o tempo gasto com ensino de estratégias de leitura e compreensão de textos, além do ensino de vocabulário. Poucos alunos acreditam que a prova avalia adequadamente os candidatos, pois enfoca somente a leitura. Talvez porque o professor estivesse equivocadamente conduzindo as aulas para o ensino da gramática e não compreensão de texto. O restante deles não soube opinar por não conhecer a prova. Muitos se queixaram de que o exame não avalia a gramática explicitamente. Um dos alunos contestou dizendo: "Como poderei compreender um texto se não compreender os tempos verbais. Sem essa ferramenta como vou resolver o texto? Na dedução?" O aluno percebeu a importância da seqüência e correlação dos tempos verbais para a progressão de um texto. Mas o que ele não entende é que a maneira como a gramática é ensinada está fundamentada em uma visão ascendente de leitura e isso pode prejudicá-lo na medida em que será muito difícil ele, por si só, fazer as relações entre gramática e texto, gramática e construção de sentido. Se o exame de inglês do vestibular da UFPR estivesse inserido no modelo interativo de leitura, tanto o aluno como o professor poderiam ter subsídios para entender que o modelo não nega o ensino da gramática ou vocabulário, uma vez que a abordagem é entendida como um processo de produção de significado em 
relação ao texto escrito, que depende de, ou se utiliza de várias ordens do saber do leitor e do escritor: conhecimento prévio de mundo, conhecimento semântico, sintático, lexical, textual, discursivo e isso é diferente de uma abordagem gramatical ao ensino de línguas com ênfase na concepção de correção gramatical. Em uma abordagem comunicativa, a ênfase passa a estar nas funções desempenhadas pela linguagem em uma dada situação comunicativa e no querer dizer do usuário da língua, seja através da observação de suas categorias gramaticais tais como verbos, advérbios, sentenças subordinadas e coordenadas; seja nas articulações das partes do texto; ou ainda no papel do texto para o contexto, seja eles textos escritos ou orais. Portanto, tanto em uma aula que tenha ênfase na oralidade como na leitura, na era comunicativa, busca-se um ensino que faça mais sentido para o querer dizer do aprendiz, para as regras de uso da linguagem para a comunicação, mais do que a simples reprodução de regras gramaticais. Porém, a visão tradicional de ensino da linguagem que enfatiza a análise apenas das escolhas gramaticais feitas pelo autor do texto a partir de um sistema ideal da língua para um leitor ideal ainda impera no ensino de língua estrangeira. Em um ensino descontextualizado da língua, cabe ao professor usar o texto como pretexto para ensinar apenas a gramática. Essa foi e, em muitos casos, ainda é a concepção do papel do professor e do texto na sala de aula de língua estrangeira: a visão interativa de leitura ainda não é totalmente entendida e operacionalizada nas práticas em sala de aula de muitos profissionais. Se o exame de inglês do vestibular da UFPR estivesse, de fato, embasado no modelo interativo de leitura, seria provável que muitos professores, interessados em preparar seus alunos para o vestibular, começassem a perceber que o ensino de gramática deveria ter um outro formato.

Alguns alunos acreditam que o exame pode ser um mecanismo eficiente de mudanças no ensino de inglês nas escolas de ensino médio. Uma aluna disse que "a partir do exame poderá ser analisado como o aluno está acompanhando a matéria". Um outro aluno afirma que o exame de vestibular "exigirá melhor qualificação das aulas de ensino médio", isso se as escolas e professores virem o vestibular como um instrumento que possa ajudá-los a planejar suas aulas e desenvolver um trabalho mais centralizado no uso da língua.

A coordenadora, professor e alunos têm consciência de que o histórico social e escolar de seus alunos os deixam em desvantagem em relação aos alunos brancos das classes média e média alta. A prova de inglês do vestibular para esse grupo é difícil e exige um esforço muito maior de todos para que esses alunos possam passar no exame. Assim mesmo, apesar da equipe não ter o conhecimento suficiente sobre o exame (filosofia que o embasa, concepções 
de língua/leitura/avaliação que estão subjacentes os exame, etc) eles se esforçam para aprovarem seus alunos . Eles utilizam o programa do vestibular da UFPR e as apostilas do Positivo para planejarem suas aulas. Documentos oficiais como os PCNs ou Diretrizes não são utilizados nem pelo cursinho e nem pela elaboradora do material didático.

A coordenadora e professor acham que se o vestibular tivesse como objetivo levar seus alunos a pensarem, a interpretarem e entenderem textos, então ele seria um bom instrumento para balizar as aulas que o precedem. Ambos se queixam, porém, de que o exame é "inconsistente" e muito difícil: percepção perspicaz, pois notaram que em um mesmo exame há questões isoladas de língua e leitura, por exemplo. A elaboradora da apostila, por sua vez, afirma que seu trabalho gira em torno do exame, independentemente de ser bem elaborado ou não. Os alunos, por sua vez, possuem um entendimento muito interessante sobre o exame. Alguns alunos afirmaram que se o exame de vestibular influenciar o ensino que o precede então isso "exigirá melhor qualificação das aulas do ensino médio".

O ensino superior para esse grupo é muito importante, pois o sucesso no exame de vestibular significa um caminho para profissionalização qualificada e assim, ascensão social e respeito.

\subsection{CURSO PRÉ-VESTIBULAR PARA BAIXA RENDA}

O curso pré-vestibular EA destina-se a adolescentes de baixa renda. Ele também recebe alunos de escolas públicas com pouquíssimo conhecimento da língua estrangeira. Seus 270 alunos travam uma batalha para poderem freqüentar o curso pré-vestibular que é oferecido aos sábados e domingos - 12 horas cada dia. Uma batalha por várias razões: muitos não têm dinheiro para pagar transporte até o local, outros não têm dinheiro para almoçar, e, além disso, todos têm que vencer o cansaço do trabalho da semana.

A dificuldade desses alunos não pára por aí. Por terem tido no máximo dois anos de ensino de língua inglesa no ensino médio nas escolas públicas, e terem cursado um fundamental fraco, os alunos enfrentam muitos obstáculos para melhorarem seu desempenho no exame do vestibular.

\subsubsection{O diretor do curso pré-vestibular EA}

Para o curso definir seus objetivos, o diretor (que também é professor de Química no curso) e professores procuram informações sobre o vestibular da 
UFPR através da mídia. O diretor reclama que o "núcleo de concursos é muito restrito e fechado a dar informações. Por isso, às vezes, a gente fica muito desinformado." Tal queixa foi comum entre todos os outros profissionais participantes dessa investigação, com exceção dos profissionais do Colégio DB e a professora/elaboradora da apostila do Positivo.

A existência do curso está vinculada à aprovação dos alunos no vestibular da UFPR - "O vestibular é nossa meta: aprovar o aluno". Para a instituição, seus alunos poderão conquistar um melhoramento do padrão de vida, se eles conseguirem ingressar e terminar um curso universitário. Como disse o diretor:

A vida deles está em função disso porque é a oportunidade deles melhorarem de vida. Então eles têm isso como a única oportunidade de melhorarem de vida. Pra eles é tudo. E a gente tenta o máximo de inseri-los na UFPR porque é gratuita. Nossa preocupação é bem grande em fazer nossos professores não faltarem. Sempre ter aulas, ter aulas a mais, ter reposições, revisão, aulão, teatro, tudo é voltado pro vestibular.

Como podemos observar através do discurso do diretor, o processo seletivo de universidades públicas é injusto: quem mais precisa de aprovação para inclusão social, é quem menos tem acesso a ele. Na verdade, o problema não está na seleção de vestibular. Ele começa com a má qualidade do ensino fundamental e médio que não propiciam condições adequadas ao alunos para competirem em grau de igualdade com os alunos das escolas particulares.

Como todos os alunos são provenientes de escolas públicas - escola com baixa qualidade de ensino - e têm pouco conhecimento da língua inglesa, é unânime a opinião de que a prova de língua inglesa da Federal é muito difícil. Para o diretor, ela não avalia adequadamente seus candidatos porque, muitas vezes, abrange determinados assuntos que não são enfocados na escola. Para o diretor, "ele [o aluno] estudou tudo e deixou uma partezinha sem estudar e, às vezes, é aquela partezinha que cai no vestibular. Às vezes, só cai isomeria e ele estudou reações orgânicas. Mesma coisa pro inglês ele estudou toda gramática e cai uma interpretação de texto super difícil." Ele afirmou que se a gramática fosse cobrada, a prova seria mais acessível aos seus alunos de escolas públicas, uma vez que a interpretação de textos exige um conhecimento muito grande da língua. Na verdade, exige que o aluno saiba ler!

[a gramática] tornava a prova mais acessível. Porque o aluno do ensino médio, o pouco que ele tem de inglês é gramática nas escolas públicas. Ele não tem interpretação de textos, então ele teria mais 
chance se fosse gramática ao invés de interpretação de texto. Interpretação exige um domínio muito maior do inglês.

A visão de linguagem, de leitura e ensino de língua estrangeira do diretor é uma visão tradicional, ou seja, ele compartilha da teoria da qual a língua deva ser ensinada em fragmentos. Como a maioria dos alunos tiveram aulas exclusivamente de gramática no ensino fundamental e médio, a leitura de textos de vestibular torna-se uma habilidade "super difícil" para eles. Ele reconhece que o ensino centrado na gramática é deficitário quando afirma que para se fazer interpretação de texto, o aluno deverá ter um "domínio muito maior do inglês". Portanto, será que o exame do vestibular é o vilão da história? Será que tal exame deve baixar seu nível para que os alunos das escolas fracas pudessem ser contemplados? O processo não deveria ser ao contrário, ou seja, as escolas não deveriam melhorar sua qualidade de ensino para que esses alunos pudessem ser capacitados para competir em grau de igualdade com os que saem de escolas particulares? Ao invés de encararmos o vestibular como um "leão-dechácara" (gatekeeper), ou seja, o que impede a entrada à universidade, não podemos vê-lo como um sinalizador de que há alguma coisa errada em nosso sistema escolar, e essa coisa errada é velada e enraizada?

Apesar das dificuldades que seus alunos enfrentam em relação à prova, o diretor acha que "se o aluno fez a prova sabendo", ele acredita que "ele [esse aluno] tenha um bom nível porque a prova é pura interpretação de texto e tem que ter um domínio da língua bem grande". Mesmo afirmando que o candidato que for bem sucedido na prova domina bem a língua, ele discorda que o exame possa ser um mecanismo eficiente de mudanças no ensino médio, o que é um contrassenso se a prova for bem elaborada e exercer um efeito retroativo positivo. Ele lamenta que muitas escolas deixaram outras questões importantes de lado para prepararem seus alunos para o vestibular. Segundo ele,

Infelizmente a escola do ensino médio é voltada para o vestibular. Até hoje não existe uma definição da finalidade do ensino médio. Porque nos últimos anos eles vivem em função do vestibular. Então, toda aquela parte pedagógica e educativa está sendo deixada de lado e a gente tem que focar o vestibular senão os nossos alunos acabam excluidos. Infelizmente é assim. Enquanto que o ensino médio deveria proporcionar ao aluno outras coisas. Além do vestibular, a formação pra cidadão, pra exercer uma profissão, encaminhá-lo pro mercado de trabalho, trabalhar a maturidade e caráter do aluno e essas coisas mais. Mas infelizmente o ensino médio está voltado somente para o vestibular. 
Em seu comentário podemos observar mais alguns equívocos. Quando ele diz que "aquela parte pedagógica e educativa está sendo deixada de lado e a gente tem que focar o vestibular", ele está afirmando que se prepararmos os alunos para o vestibular, estamos negligenciando "a formação para a cidadania", "a formação para exercer uma profissão, para encaminhá-los pro mercado de trabalho". Mas, quando um profissional entende todas as concepções que estão por trás do exame, quando esse profissional entende relacionar o exame, sua prática de ensino com o contexto atual de nosso mundo, preparar para o vestibular e preparar para a cidadania e para o trabalho deveriam fazer parte de um único processo. Um bom profissional consegue preparar seus alunos para a cidadania, para o trabalho e para o vestibular. O discurso de que "eu preparo para a vida e não para o vestibular" transformou-se numa fala do senso-comum, e proferido por profissionais que não estão em sintonia com as concepções e teorias atuais de educação.

Com todo o esforço da equipe do curso pré-vestibular dessa escola, no ano de 2002 foram aprovados 20\% dos alunos na UFPR e no CEFET. No ano seguinte, a taxa subiu para 40\%, o que foi comemorado com entusiasmo.

\subsubsection{As percepções do professor do curso pré-vestibular EA}

O curso pré-vestibular EA é também uma instituição voltada para alunos de todas as etnias e raças carentes. Como define o professor de inglês do curso, "E. A. é um curso para alunos incrivelmente carentes". A instituição tem como meta principal ajudar seus alunos a terem ascensão social através dos estudos superiores em universidades públicas. Segundo o professor, o trabalho do E. A. é bem grande. "Há uma preocupação até exagerada em aprovar seus alunos na UFPR". No ano de 2003, 40 \% dos alunos foram aprovados na Universidade Federal do Paraná.

Apesar de os alunos não verem utilidade imediata da língua inglesa no dia-a-dia, eles estudam e se interessam pela disciplina mais do que os alunos das escolas particulares nas quais o professor trabalha. Ele chama a atenção para as duas realidades antagônicas nas quais ele trabalha:

Eu ouço isso muito aqui. A gente já ouve em algumas realidades: 'Ah eu não vou usar no serviço.' Mas a maioria diz, infelizmente: 'É professor, com minha realidade... Onde é que vou usar?' 'Nunca pude estudar numa escola boa de inglês, não vou poder viajar fora.' Etc, etc. Mas em contra partida, eu vejo mais interesse aqui [interesse 
dos alunos da escola pública em aprender inglês] do que nos nossos do particular. Isso é muito gratificante.... Aqui [na escola pública] existe e no particular você tem outro status por outras razões, mas isso [vontade de aprender dos alunos da escola particular] de jeito nenhum.

Tal sentimento também é compartilhado pela coordenadora de Inglês da Secretaria Estadual de Educação, que também percebeu a diferença de motivação em aprender língua estrangeira dos alunos de baixa renda e os alunos de escolas particulares.

Suas aulas são desenvolvidas a partir do programa que a Universidade Federal do Paraná publica, pois o objetivo maior do E. A. é aprovar o maior número possível de seus alunos. O professor comenta que apesar de gostar bastante da organização dos PCNs, ele centraliza seu trabalho na realidade da Federal, uma vez que a meta do curso é auxiliar alunos de baixa renda a entrarem em uma instituição de ensino superior pública. Portanto, ele não utiliza nenhum documento oficial para planejar suas aulas: prática comum entre todos os professores de escolas particulares e cursos pré-vestibular. Na verdade, a priori, o planejamento do ensino para o vestibular não deveria diferir do planejamento feito a partir dos PCNs, já que ambos - o programa do vestibular e os PCNs - deveriam preparar o aluno para a cidadania, para o trabalho e para a vida acadêmica.

A instituição orienta seus professores para a realidade dos alunos e os incentiva à se dedicarem ao máximo para alcançar os objetivos. O professor também tem a preocupação de sempre trazer informações novas sobre o vestibular da Federal para o curso EA. As informações são obtidas na instituição particular na qual ele trabalha, pois tal escola tem como meta preparar seus alunos para o vestibular.

Tanto a instituição, quanto o professor possuem uma responsabilidade muito grande em relação à aprovação de seus alunos na Federal. O professor ressalta:

Especificamente, aqui no E. A., acho que talvez não seria só aqui, nós temos uma responsabilidade muito maior, porque essas pessoas têm mais dificuldades....A nossa obrigação de ajudá-los a passar é muito maior do que uma escola particular. O aluno coloca uma esperança toda em você. Eu tenho visto, apesar de poucos meses aqui, que é um fardo grande... motivacional, é verdade ... mas tem que existir essa responsabilidade. Mas eu acho demais... demasiado. Pros alunos é tudo. Eles só pensam nisso. 
A ação de ajudar alunos de baixa renda a terem uma ascensão social através da educação mostra a consciência política dos profissionais que trabalham no curso. Porém, o professor afirma que sua responsabilidade acaba virando um fardo pesado, pois a preparação para o vestibular é uma tarefa muita árdua.

Para o profissional, a prova de língua inglesa é bastante difícil: "se para os professores já são difíceis, imagine para os alunos. De uma forma ou de outra vai "tá prevalecendo quem??" O professor chama a atenção para um aspecto interessante: as provas de língua inglesa do vestibular da UFPR também são difíceis para muitos professores. Isso mostra que o nível dos profissionais atuando no mercado é baixo. E quando ele afirma "prevalecendo quem", ele se refere ao aluno da escola particular cuja qualidade de ensino é melhor, e, portanto, quem 'leva vantagem' na disputa por uma vaga na instituição publica superior são eles.

Apesar dos "textos serem interessantes, na sua opinião, o candidato acaba tendo que lidar com a língua de uma forma mais abrangente" do que quando cobrava somente gramática. Porém ele reclama - tal como os professores dos colégios DB e DP - que, às vezes, os textos escolhidos são muito técnicos como textos de clonagem humana, indústria, estatística - e por esse motivo o conhecimento de vocabulário tem que ser muito maior. Porém, ao meu ver, se o professor conseguir preparar seus alunos de tal forma que eles adquiram um conhecimento sistêmico da língua razoável, e se eles aprenderem a lidar com estratégias de leitura, o vocabulário desconhecido não deveriam ser um empecilho para uma boa compreensão. Na escola particular na qual ele trabalha, ele lida com o vocabulário e textos desde o primeiro ano do ensino médio e tenta trabalhar interpretação de textos e ensino de vocabulário desde o primeiro dia do curso pré-vestibular. Ele também critica, severamente, os professores que ainda estão enfocando suas aulas no ensino da gramática. Ele revela sua opinião sobre o ensino da interpretação de textos versus da gramática ao enfatizar:

Acho que nesses últimos anos onde a ênfase acabou sendo totalizado nos textos.... Textos são muito interessantes. Você acaba lidando com a lingua de uma forma mais abrangente, mas por outro lado, tem aparecido textos técnicos ao extremo, de clonagem humana, de indústria, de estatística e, às vezes, mal se entende esse assunto. No contexto de nossa língua, já é difícil, imagine em outra. E o vocabulário é muito maior. Então, hoje eu vejo que tem que ser um trabalho desde o começo do ensino médio. No primeiro, segundo e terceiro... dicionário em sala. Dificilmente se usa isso em sala, que é uma pena, 
trabalho com textos. Tem professores que estão brincando de trabalhar só gramática individualizada. Aquela de fill in the blanks. Claro você volte e meia coloca isso, mas não exigir em provas apenas isso ....Isso está mais que pré-histórico. E o que acontece? Ai vem o terceiro ano ou cursinho e é uma bomba!!!! O aluno diz: "Cadê aquele do e does pra gente ficar preenchendo?" Não são textos de duas ou três linhas....são textos técnicos, vocabulário complicado...aquelas pegadinhas "according to the text" que não é sua opinião que vale. Mas é o que está escrito.

O fato dos textos serem de assuntos variados, com vocabulário "técnico", não deveria ser um empecilho para a compreensão, muito pelo contrário. O aluno que deseja continuar sua carreira acadêmica deve ser bem informado sobre diversos assuntos e ter capacidade de ler textos acadêmicos e técnicos. Não seria produtivo o exame utilizar textos 'mais fáceis', ou 'menos técnicos'. Os elaboradores deveriam sim padronizá-los - em termos de grau de dificuldade de textos e tipologia de questões - para que os professores e escolas soubessem que tipo de leitura o exame realmente avalia. Mais uma vez, não dá para baixar o nível do exame do vestibular (seria necessário melhorá-lo), o ensino fundamental e médio é que têm que melhorar em qualidade. E, apesar dele advogar contra o ensino de gramática, ele ainda tem concepções antigas sobre o ensino de leitura. Podemos notar isso quando ele diz "aquelas pegadinhas"according to the text" que não é sua opinião que vale." Se ele tivesse a concepção de leitura como uma prática social na qual o leitor vai construindo o sentido, ele não veria a questão "de acordo com o texto" como uma pegadinha. O ensino de macetes é resquício de uma época na qual os exames eram de má qualidade e avaliavam somente fragmentos da língua ou tradução.

Desde o momento que o professor decidiu sair do instituto de línguas no qual se trabalha primordialmente a oralidade, e migrou para cursos pré-vestibulares e terceirões, ele mudou radicalmente sua prática em sala de aula. No início da mudança, uma sensação de frustração tomou conta dele por achar que "não estava ensinando nada". Depois de um período de adaptação, o professor percebeu a nova necessidade dos alunos e começou a trabalhar com novos objetivos. Ele demonstra sua inquietação ao falar sobre essa mudança na sala de aula:

Pra mim foi frustrante a primeira vez, porque parecia que você não estava ensinando nada. Aquilo que você tinha a chance de ensinar...E é técnico. Não adianta dizer que o ensino médio para o vestibular 
virou inglês técnico. Muito em função do vestibular de texto na Federal. Todos os alunos estão preocupados com o inglês técnico da Federal. Aliás, uma vez na semana trago curiosidades, cultura da língua, raízes da língua inglesa. A minha experiência no exterior foi muito legal então eu gosto de trocar esse tipo de ideia com aluno. Infelizmente, você não se desmotiva, porque você ainda tem tesão de dar aula. Mas hoje eu começo a ver que é fácil, se a gente não tomar cuidado, em se desmotivar ou ficar na mesmice. Porque está tão técnico que você é meio que levado a .... uma vez já fui chamado a atenção, não aqui é obvio, porque eu estava dando mais ênfase em coisas de conversação etc, etc, etc, mas as provas e os resultados eram pra preparar a garotada pra dois, três anos pro vestibular.

Os textos do exame de inglês da UFPR, na verdade, não são textos técnicos como afirma o professor. São textos de vulgarização científica. A inquietação do professor acontece porque seus alunos não têm (ou têm muito pouco) conhecimento da língua inglesa para dar conta da complexidade desse tipo de textos. Um outro ponto a ser comentado é a inquietação do professor com a negligência da 'conversação'. O preparo para o vestibular não significa que a fala não possa ou não deva ser trabalhada: a integração de habilidades, como, por exemplo, a fala e leitura, faz parte de concepções correntes de ensino e avaliação em LE. Apesar das dificuldades que seus alunos enfrentam, o professor se mostra bastante interessado em enfrentar mudanças e inovações, mesmo que elas tenham sido impostas pela escola. Ele comenta:

Como gosto de pesquisar e moldar, sou bastante autocrítico - digo que até demais - acho que toda mudança é interessante. Nem sempre ela vai ser melhor, mas é interessante encará-la. Por outro lado, não adianta negar, como muitos fazem 'não adianta só pensar no vestibular'. Tudo bem, eu posso pensar isso, mas se os outros 200 estão pensando assim eu vou brigar com eles? Ainda mais de um colégio que vive de resultado de vestibular!!!

O professor mostra preocupação constante em estar em sintonia com o que está acontecendo com os vestibulares, especialmente com o da Federal. Demonstra vontade de trabalhar outras habilidades e competências, mas a própria exigência do curso e dos alunos faz com que ele priorize o preparo para o exame, que para esse grupo é somente gramática, vocabulário e leitura. Como ele jocosamente coloca "a gente quer acertar o que vai cair na Federal: Mãe Dina's power!" 
Ele lembra que quando dava aulas no centro de língua e ensino fundamental, ele se sentia mais satisfeito com suas aulas e com os resultados delas: "eu me sentia mais professor, trazendo mais conhecimento não apenas de uma coisa que eu chamo de ROBO COP's LANGUAGE."

Sua inquietação tem fundamento. Quando ele dava aula em um instituto de línguas, ele trabalhava todas as habilidades, gradativamente, até que os alunos chegassem a uma competência lingüística desejada. O progresso dos alunos era visível. Quando ele passou a dar aulas somente para o vestibular, ele cometeu o equívoco que a grande maioria dos professores comete: pensar que dar aula de leitura é dar aula de gramática, vocabulário e estratégias de leitura. Tanto a gramática quanto o vocabulário são ensinados de uma maneira descontextualizada, e muitas vezes, de forma estruturalista. Então, nesse caso, fica muito mais difícil o aluno aprender a ler, pois ele fica preso no aprendizado fragmentado da língua. A impressão que o professor tem de que "não ensina tanto quanto antes" é procedente. Quando ele chama a língua que ele ensina de ROBO COP's LANGUAGE, ele faz uma analogia entre a artificialidade e limitação de um robô (limitação de movimento e pensamento) com a limitação do ensino que ele oferece no ensino médio. Realmente, com turmas de cem alunos e com aulas centradas em gramática, vocabulário e estratégias de leitura limitadas (os 'steps' do professor) o desenvolvimento da habilidade de leitura se torna uma meta difícil de ser atingida. Por isso que é necessário o poder divino da 'Mãe Dina' para ser bem sucedido no exame. Podemos notar um equívoco que sua prática revela. Há uma necessidade de uma teorização maior acerca de modelos interativos de leitura.

O baixo nível de língua inglesa que os alunos trazem do ensino fundamental e médio, as classes numerosas, tudo isso aliado às concepções tradicionais do ensino de leitura de língua estrangeira fizeram com que o professor deixasse de fazer muitas coisas em sala de aula: "especialmente ter prazer da língua, de ensinar a falar. Tudo se perdeu". O ensino das quatro habilidades deu lugar somente ao ensino para o vestibular, segundo ele.

O professor desabafa quando fala sobre sua experiência em um colégio estadual:

Eu estou agora substituindo no Colégio Estadual três manhãs até dezembro... horrível. Eles ficaram sem professor de inglês por cinco meses no ensino médio. O nível do professor de Estado é terrível. Ao invés de falar 'to be' fala 'tobi'. É complicado. Todo mundo passa em inglês. É fácil,... fácil por quê? É só preciso preencher lacunas, aquelas 
coisas antigas. A gente precisa moralizar isso, cobrar qualidade. Cobrar outras coisas, mas desde lá da $5^{a}$ série. Acho que esse interesse não existe na educação. É bonito falar, mas no colégio... Em primeira lugar o inglês é tido como aulinha extra. 'As tias' dão aula de inglês. O que que é isso???"

Pelo discurso do professor, podemos claramente observar que ele não está contente com sua prática em sala de aula. Ele atribui as mudanças de posturas em sala, além do abandono do ensino da fala, compreensão auditiva e escrita, ao exame do vestibular: ter que focar somente leitura, ter que dar aula para mais de cem alunos, ter que dar aula para alunos sem conhecimento sistêmico da língua. Porém, vemos esse descontentamento como algo salutar, pois sua inquietude demonstra que ele é consciente de que algo está errado. Ele somente não sabe ainda pontuar o problema.

Pelo fato de não conseguir avançar muito com seus alunos, em termos de aprendizagem da leitura, o professor acha que o exame de vestibular da UFPR não deveria ter a força que tem sobre o ensino de escolas particulares e cursos pré-vestibulares. Ele também acha que o exame não deveria ser um mecanismo de mudanças no ensino de inglês nas escolas do ensino médio. "Não é o exame que deveria influenciar as escolas, mas o contrário. Lamentavelmente eu acho que hoje isso seria até pretensioso". Visão questionável do professor. $\mathrm{Se}$, de fato, as escolas influenciassem os vestibulares correríamos o risco de não somente ter um ensino fundamental e médio deficitário, mas um ensino superior também. O que tem que ser mudado é o ensino que precede o vestibular e não o vestibular.

Ao ser perguntado se ele achava que o exame do vestibular da UFPR avalia adequadamente seus candidatos, o professor disse que o vestibular não condiz com o que é ensinado no fundamental e médio. Primeiramente, as aulas do fundamental geralmente são muito fracas, longe do trabalho feito em escolas de línguas, o que seria perfeitamente possível fazer, segundo o professor. Depois, no ensino médio, a superlotação das classes com um público acima de 60 alunos. O que resta fazer no ensino médio com turmas grandes e com pouco conhecimento sistêmico do inglês é "ensinar para o vestibular. Você joga tudo no data show e joga textos". Ensinar para o vestibular deveria exigir do professor muito mais do que somente jogar informações no data show e mostrálas aos alunos. Deveria exigir um conhecimento profundo do que é saber uma língua, o que é ensinar uma língua, bem como o que é avaliar essa aprendizagem. Deveria exigir, também, dos governos estaduais e municipais uma política 
de educação séria e embasada em teorias e concepções recentes de ensino, avaliação e gestão.

Apesar do professor trabalhar interpretação de textos em sala de aula porque o vestibular avalia isso, a maneira como a leitura é abordada e ensinada não dará aos alunos embasamento suficiente para poderem ser bem sucedidos.

\subsubsection{As aulas do professor do curso EA}

O professor do curso E. A. dá aula para aproximadamente cem alunos. Como ele não se sente satisfeito com a apostila adotada, para conseguir preparar seus alunos para a prova de língua inglesa da Federal, o professor trabalha essencialmente os textos, o vocabulário e a gramática contida neles. As apostilas utilizadas no curso são direcionadas para o vestibular da Federal: os conteúdos são baseados nos simulados de provas originais anteriores. Ele trabalha os pontos gramaticais, e em seguida trabalha os textos da apostila. Como seus alunos têm pouco conhecimento da língua, ele elaborou uns 'steps' (passos) para facilitar tanto a leitura como a "procura das respostas nos textos" (pinçar a resposta do texto). Os passos são:

Step 1 - circular números, valores e nomes próprios

Step 2 - circular verbos

Step 3 - palavras conhecidas

Step 4 - estudar título, rodapé e fonte

Step 5 - lê as alternativas e depois vai pro texto

Ao trabalhar os textos (Anexo F.1. p. 1 e 2), o professor utiliza os 'steps' pedindo para os alunos acharem as respostas dos passos e colocando, na lousa, os verbos principais e vocabulário que aparecem no texto. Todas as palavras são traduzidas para o português. Se observarmos os textos, verificaremos que foram textos de exames anteriores da UFPR. Tantos os textos I, II e III têm questões de reconstituição de informação linear, não linear e global, apreensão de julgamento de valor, e de gramática. Na verdade, essas estratégias desenvolvidas pelo professor para ajudar seus alunos, não são estratégias de leitura, mas estratégias para lidar com as dificuldades desses alunos.

Depois de percorrer os cinco passos com os alunos, o professor lê os textos em voz alta, traduz alguns trechos e pede a alternativa correta para os alunos. Os alunos deveriam já ter lido o texto e respondido as questões em casa. Na aula, ele somente corrige as questões. 
A visão de leitura por de trás dos passos - circular números, nomes, verbos e palavras desconhecidas - indica que ele tem uma concepção de leitura embasada em estratégias ascendentes de leitura. O ensino de macete não garante ao aluno que ele tenha uma boa compreensão do texto. Muito pelo contrário, o aluno poderá ficar tão centrado em partes do texto, que não conseguirá ter uma visão ampla dele. Estratégias de leitura como criar hipóteses do texto para, ao longo da leitura confirmá-las, refutá-las ou mudá-las, inferir significados de palavras desconhecidas pelo contexto, reconstruir a cadeia argumentativa do texto, dentre outras, nunca foram trabalhadas em aula.

Os pontos gramaticais são sintetizados na lousa com explicações detalhadas do professor. O ponto gramatical (Anexo F.2. p. 3) foi colocado na lousa. Depois, o professor pediu a tradução das expressões interrogativas, e logo em seguir, os alunos fizeram os exercícios propostos pela apostilas, exercícios esses que são atividades tirados de livros de gramática, ou questões antigas de gramática de diversos vestibulares do país.

Como os alunos têm aulas somente nos sábados e domingos - 12 horas cada dia - ele pede para que os alunos façam as folhas da apostila durante a semana para que eles possam avançar mais rapidamente nas aulas e dar conta do conteúdo proposto.

Os simulados são dados depois do segundo semestre, e as provas são comentadas em sala de aula após a correção. No geral, as aulas são a do Método Gramática-Tradução - explicação gramatical e tradução dos textos. Algumas estratégias - skimming, scanning, cognatos, do Instrumental, são mencionadas esporadicamente nas aulas.

Assim como os professores dos Colégios DB e DP, o professor do E. A. tem a mesma prática de sala de aula. Para esses profissionais, o ensino de gramática e vocabulário são dados de forma não contextualizada e fragmentada, e o ensino de leitura também se restringe, muitas vezes, às estratégias ascendentes, apesar deles utilizarem esporadicamente estratégias descendentes.

\subsubsection{A apostila do curso pré-vestibular EA e as percepções de seu elaborador}

A elaboradora das apostilas Unificado desenvolve material didático há 25 anos. Ela já lecionou em várias escolas de Curitiba como Instituto de Ensino Camões, Colégio Bom Jesus, Colégio Santa Maria, Dom Bosco, Marista Paranaense e, paralelamente, sempre trabalhou no Colégio Unificado. 
O objetivo maior do material didático é de preparar os alunos para os vestibulares da cidade, principalmente para o exame da UFPR. Como ela ressalta: "O meu material faz o possível para preparar um aluno para ser um bom leitor". Ela também leciona no Colégio Unificado. O público que o freqüenta é basicamente de classe $\mathrm{B}$ e $\mathrm{C}$ que vieram de outras escolas particulares de classe B e C ou do ensino público. Ela afirma que, como a maioria de seus alunos vem de escolas públicas, eles têm pouca base para desenvolver interpretação de texto e não "valorizam o aprendizado da língua por achá-la muito difícil". Para a escola não ter uma grande imigração das aulas de inglês para o espanhol, a autora tem bastante cuidado na elaboração de suas apostilas: o material começa do mais elementar, em termos gramaticais, de vocabulário e de interpretação de textos, e vai progressivamente incluindo estruturas, léxico e textos com maior grau de dificuldade. Ao escrever seu material, a autora pensa em um professor com bom nível de conhecimento, porque "não dá para nivelar por baixo", segundo ela. Apesar de ter o cuidado de escrever apostila com bom nível, muitos professores não conseguem resolver os testes nela propostos, segundo as autoridades da escola que comercializam o material.

Os objetivos para o desenvolvimento do material são estabelecidos a partir dos conteúdos trabalhados nos vestibulares. Os PCNs são consultados, mas o que de fato direciona as apostilas são os programas dos vestibulares, principalmente o programa da UFPR, como os outros materiais didáticos usados pelas escolas particulares e cursos pré-vestibulares. Já que o enfoque maior do material didático da autora é o desenvolvimento da leitura, as apostilas são centradas em compreensão de textos e o ensino de gramática aplicada e expansão de vocabulário. Os textos utilizados nos materiais são de diversas áreas de conhecimento: saúde, comportamento, ciências. O ensino tanto da gramática, quanto do léxico fica atrelado aos textos desenvolvidos. A autora acha muito bom do exame não mais avaliar a gramática explicitamente: "avaliar a gramática sim, mas através dos textos". Ela também ressalta que o vestibular também norteou seu material na escolha do conteúdo a ser trabalhado, na seleção e seqüência das atividades, mas não na metodologia: "a metodologia acho que não mudei! Porque a metodologia é uma coisa mais profunda, né? A ênfase eu mudei. Muito tempo pra cá é no texto, mas não a metodologia”. Esta fala pode sinalizar que a elaboradora/professora continua ensinar a leitura e gramática embasada em uma concepção de ensino de LE estruturalista, como os outros professores desta investigação. Apesar de as apostilas terem uma variedade grande de atividades, a elaboradora pensa que um professor criativo deva utilizar material complementar como música, outros textos autênticos de revistas e jornais ou qualquer outra atividade que auxilie na aprendizagem. 
A autora tem uma preocupação grande em procurar informações sobre os vestibulares para sempre estar atualizada. Ela ia às reuniões que aconteciam com a comissão do vestibular da UFPR. Há também uma intercomunicação entre os colegas dos cursos pré-vestibulares da cidade. Além disso, ela fez uma análise de todos os vestibulares da UFPR desde 1985 até os dias atuais. Os textos da prova de língua inglesa do exame da UFPR não são fáceis, segundo a elaboradora. Há textos que são razoáveis, mas há outros que são muito difíceis - opinião compartilhada pelos outros professores das escolas particulares e cursos pré-vestibular. Em um exame, há "um equilíbrio de textos fáceis e difíceis para poderem realmente selecionar adequadamente seus candidatos". Há alguns anos, os textos das provas de língua inglesa não eram adequados aos candidatos. "Eram textos muito complexos e de assuntos totalmente fora da realidade de um adolescente: reclamação comum entre os outros professores desta investigação. Hoje os elaboradores do vestibular já estão escolhendo os textos mais adequadamente para o público jovem". Segundo a elaboradora, o exame prima em classificar o bom leitor e não "o conhecimento real da língua inglesa". O que a elaboradora/professora desconhece é que, apesar de avaliar leitura, o exame focaliza sua leitura e questões em reconstituição de informações, e às vezes exige do aluno/candidato que ele infira algumas informações, mas deixa de trabalhar com um nível de leitura mais complexo, mais argumentativo.

Para a elaboradora do material do Unificado, o vestibular tem um papel muito importante nas vidas dos professores e alunos, pois o exame faz com que todos trabalhem e estudem muito mais. Ela nos chama a atenção:

É o vestibular que mais faz com que as pessoas se empenhem. Estudar e ensinar. Como ela [o vestibular da UFPR] é a mais concorrida, então é o que dá mais trabalho, né? Dá mais trabalho pra você preparar. Você tem um ano pra você preparar. Dá mais trabalho para se preparar.

A citação acima mostra um dos efeitos retroativos positivos do exame de inglês do vestibular. Por esse motivo, ela advoga que o exame de vestibular é um mecanismo eficiente de mudanças no ensino de inglês nas escolas do ensino médio. Ela afirma que os terceirões e cursos pré-vestibulares vivem em função do exame. Se o vestibular decide mudar a forma de avaliação, então todos [cursos de terceirões e pré-vestibulares] irão concentrar seus esforços para se adequarem às mudanças - novo material didático, reuniões, treinamento de professores, pesquisas, estudos, análises etc. Segundo a autora, "o vestibular da UFPR dita tudo, desde o conteúdo até a forma de avaliação". O exame exige do professor/elaborador/diretor que eles procurem mais informações 
e trabalhem mais para prepararem seus alunos satisfatoriamente, por um lado, e, por outro, exige que os alunos se empenhem, estudem mais para poderem alcançar um nível de conhecimento necessário para serem bem sucedidos, mesmo que esse nível de leitura seja mais simples de reconstituição de informação.

Apesar de preparar seu material a partir do programa de inglês do vestibular da UFPR, e, a partir da análise de exames anteriores, sua concepção de o que é ensinar uma língua estrangeira não mudou, pelo fato dela fazer a mesma coisa que os outros elaboradores de apostilas fazem: dividem a apostila em três partes - gramática, vocabulário e textos - e abordam os três itens de uma maneira bem estruturalista.

\subsubsection{Os alunos do curso pré-vestibular EA}

A maior heterogeneidade de idade dos alunos é a do curso pré-vestibular EA Eles têm entre 19 a 50 anos. São alunos extremamente carentes, não somente com dificuldades financeiras, mas alguns também enfrentam problemas de saúde: desde doenças degenerativas, deficiências visuais e auditivas e até câncer. Todos têm uma grande vontade de vencer a etapa do vestibular e procuraram o E. A. pelos seguintes motivos:

"Um ensino médio, não tão bom, para concorrer, com aqueles que além de terem estudado o seu ensino médio em ótimos colégios particulares, complementam com mais um cursinho, sendo este, também um dos melhores."

"Realizar o sonho e provar a várias pessoas que sou capaz de entrar na Universidade."

"Em primeiro lugar o sonho de cursar uma universidade, e em segundo por ser um pré-vestibular gratuito."

"Necessidade de atualizar-me e obter melhor preparação para disputar uma vaga gratuita na universidade."

"Vontade de cursar uma faculdade que é gratuita, além de ter excelentes professores."

"Ver conteúdos nunca vistos na escola pública e preparar-se melhor para o vestibular."

"Falta de preparo em relação à escola pública. Preciso aprender mais e passar no vestibular."

A maioria dos alunos teve aulas da língua inglesa no ensino fundamental e em pelo menos um ano no ensino médio. Todos são conscientes do pouco 
conhecimento que têm da língua e da defasagem de conhecimentos em relação às escolas particulares. Uma aluna ironicamente afirma que "não é possível se comunicar usando apenas o verbo "to be" - fazendo uma alusão as aulas de inglês que teve em todos os anos da escola pública. Uma outra aluna descreve como o curso pré-vestibular irá ajudá-la com a prova de língua inglesa: "as aulas vão me ajudar muito, principalmente, em não zerar a prova, que já é um obstáculo a menos", pois, geralmente, esses alunos tentam ingressar em cursos que não exigem uma alta pontuação. A maioria dos alunos reclama que somente no curso E. A. é que eles estão tendo aulas que deveriam ter tido na escola pública, como descreve uma outra aluna: "o que eu aprendi no cursinho é ótimo, mas se eu dependesse do que aprendi na escola pública, não passaria com certeza. O cursinho traz um ótimo preparo". Para essa aluna, o cursinho traz tantas novidades, em termos de conteúdos, que ela acha ótimo. Na verdade, ela desconhece toda situação complexa, vivida por esses alunos, da falta de pré-requisitos (conhecimento prévio) para poderem acompanhar as aulas e se desenvolverem para serem bem sucedidos no exame. Ainda um terceiro aluno salienta: "a escola pública se prende muito em gramática, é muito limitado o tempo para se trabalhar textos". Um aluno consciente de suas limitações diz: "boa nota não! [referindo-se que não vai tirar uma boa nota na prova] o que aprendi aqui ajudará a manter-me na disputa com os concorrentes somente" [referindo-se aos cursos que não exigem altos scores].

Como a maioria dos alunos trabalha durante a semana, tem pouco tempo para estudos complementares. Muitos, em função da prova, se concentram em interpretação de textos, mudaram a maneira de estudar a língua: uns dedicam mais tempo com compreensão dos textos e memorização do vocabulário, outros dão mais ênfase na tradução dos textos e continuam a estudar a gramática e a maioria seguem 'os steps' - método que o professor utiliza para explorar os textos. Há aqueles também que aprenderam a língua e desenvolveram a leitura a partir dos jogos de RPG da WEB. Mesmo assim, a grande maioria sabe que o conhecimento de uma língua estrangeira e um título de um curso superior lhes trará melhores oportunidades profissionais e, em conseqüência disso, ascensão social. Como citam vários alunos:

"É necessário para entender e escrever na web e ascensão profissional e comunicação em viagens a médio e longo prazo." "A língua é muito requisitada no mercado de trabalho." "Está diretamente relacionado à minha futura profissão." "Além de gostar, eu posso usar na minha profissão." 
"As pessoas pensam ser importante, pois hoje, o mercado de trabalho é exigente, necessitando de profissionais que possam atender a vários tipos de clientes, inclusive os que falam o inglês."

"Mercado de trabalho é o maior desafio."

Os mais pessimistas acham que nunca terão a capacidade de aprender a língua como os alunos das classes A e B. Como um deles disse: "creio que eu não tenho muita noção. Para eu aprender outras línguas é gratificante, mas poder me comunicar usando outra linguagem é fantasioso."

Além de todas as dificuldades financeiras que tais alunos têm, um outro fator limitador é a dificuldade em obter informações sobre o vestibular da UFPR. Eles conversam com colegas, professores do cursinho, buscam informações nos jornais locais. Os que têm acesso à Internet procuram informações para repassarem aos colegas de classe.

A prova de língua inglesa do vestibular da UFPR, para metade da turma, é difícil, e razoável, para a outra metade. Muitos acham que a prova de língua inglesa do exame de vestibular da UFPR não avalia adequadamente os candidatos, pois "nem todos os candidatos tiveram um bom ensino durante suas vidas" - mesmo argumento equivocado usado por muitos participantes desta investigação. Um outro aluno afirmou que o exame "cobra muito acima do conhecimento do segundo grau, excluindo os pobres que contaram somente com o que aprenderam no colégio público." Eles bem esclarecem que para aqueles alunos que tiveram um ensino [fundamental e médio] adequado, o exame avaliará as capacidades de interpretação de textos e conhecimento de vocabulário. Para tentarem recuperar o atraso, os alunos estão trabalhando intensivamente com interpretação de textos, e desenvolvimento da gramática e vocabulário aplicados aos textos, segundo esses alunos. Eles também têm consciência de que a abolição da cobrança explícita da gramática dificulta seu desempenho no exame - uma vez que a grande maioria somente aprendeu gramática na escola - mas ressaltam que a cobrança da interpretação de textos está mais afinada com os novos conceitos do ensino de língua estrangeira. Um aluno assegura que a abolição da cobrança da gramática impede que os alunos desenvolvam macetes para responder às questões, o que pode ser considerado um efeito retroativo positivo e já mencionado pela professora do Colégio DP.

Ao serem perguntados se o exame pode ser ou é um mecanismo eficiente de mudanças no ensino de inglês, nas escolas de ensino médio, alguns alunos disseram:

"Não, porque senão já seria há muito tempo." 
"Com certeza, pois nas escolas é praticamente só a gramática e as traduções de textos 'apenas' com o dicionário."

"Não. Porque se fosse para mudar, já teria acontecido. Na minha opinião é uma prova (como todas as outras) que só privilegia a elite que tem dinheiro para fazer bons cursos e viajar par o exterior. E é essa realidade que eu pretendo mudar. Quando eu for professora, pretendo ajudar os jovens a ter um preparo adequado para uma prova tão difícil e decisiva na vida de todos."

"Se o ensino médio fosse voltado para o vestibular, deveriam mudar o modo de ensinar: fazerem mais textos, mais vocabulários, mas a maioria dos colégios públicos não faz isso, muitos professores levam tudo muito no "oba-oba."

"Sim. Falta inglês nas escolas: é muito básico."

"Apenas nas particulares, pois nas públicas ninguém se preocupa com essas coisas!”

"Realmente o ensino de inglês precisa melhorar nos colégios."

Alguns alunos têm uma visão bem politizada do problema como o terceiro e sexto comentários, e a grande maioria acha que o exame deveria influenciar principalmente as escolas públicas, o que não acontece hoje. O vestibular da UFPR para esses jovens tem um papel determinante em suas vidas pessoais e profissionais. Para muitos deles, o ingresso na universidade é a única saída que eles encontram para progredirem enquanto cidadãos. Tendo consciência disso, muitos alunos demonstram suas preocupações ao relatar:

"Fiquei tensa, irritada e não durmo bem."

"Deixei de dormir."

"Durmo menos e estudo mais."

"Estudo em casa, no ônibus, onde dá."

"Além do cursinho, estudo de três a quatro horas por dia."

"Minha forma de ver a vida ficou mais crítica."

Passar no vestibular da UFPR para esses alunos é uma tarefa árdua para quem veio de uma estrutura educacional pública frágil.

Os alunos do curso E. A. esperam que o professor trabalhe mais interpretação de textos em sala de aula. Porém, o que não está claro nem para o professor, nem para eles, é que um ensino de leitura não deve se restringir ao ensino de gramática, vocabulário - muitas vezes descontextualizado - e somente ascendentes. 
Neste cenário, como no curso KN, todos os sujeitos são conscientes da defasagem do conhecimento que os alunos têm da língua em relação aos alunos das escolas particulares. Com exceção da elaboradora da apostila, o coordenador, o professor e os alunos acham a prova de inglês difícil. Nem o coordenador e nem o professor acha que o exame possa ser um mecanismo eficiente de mudanças no ensino médio, isso porque o coordenador assevera que as escolas particulares vivem em função do vestibular e negligenciam aspectos pedagógicos importantes como formação do cidadão e preparação para exercer uma profissão. Se esses profissionais entendessem que um exame de alta relevância bem elaborado e pautado em uma filosofia pedagógica que se preocupa no desenvolvimento de um cidadão crítico pode contribuir para que tal filosofia seja garantida em sala de aula, então eles poderiam passar a ter uma visão de que um exame pode ser um instrumento potencial para exercer uma influência positiva no ensino que o precede.

O professor, por sua vez, reclama que o vestibular estreitou o currículo quando "forçou" as escolas a ensinarem apenas leitura, deixando de lado a oralidade, compreensão auditiva e produção escrita. Sua visão do exame fez com que ele restringisse suas aulas ao "ensino de leitura para o vestibular". Porém, os alunos afirmam que se as escolas públicas melhorassem o nível das aulas de inglês, eles poderiam competir em grau de igualdade com os alunos das escolas particulares.

Nos cenários dos cursos pré-vestibular, observamos que existe a mesma preocupação dos colégios particulares: aprovar seus alunos em instituições públicas superiores, e por esse motivo, esses cursos são influenciados pelo exame de vestibular da UFPR. Os coordenadores dos cursos KN e EA não participam do planejamento da disciplina e deixam para os professores a tarefa de procurar informações sobre o exame e material complementar para ser utilizado em aula como acontece no Colégio DP. Eles não se envolvem no planejamento das disciplinas, mas foram os responsáveis pela escolha das apostilas. Tanto o professor do curso KN como o do curso EA priorizam a interpretação de textos em suas aulas, mas ainda trabalham com o vocabulário e gramática com itens isolados e descontextualizados. Toda vez que o texto trabalhado era sobre um assunto interessante, o professor do KN o utilizava para suscitar debates sobre preconceitos, segregação, drogas e outros temas atuais, contribuindo assim para a formação do aluno enquanto cidadão crítico. Essa prática não era comum entre os professores do curso EA nem dos Colégios DB e DP.

Diferentemente dos alunos dos Colégios DB e DP, nos cursos pré-vestibulares para afrodescendentes e alunos de baixa renda pudemos notar um 
efeito retroativo positivo em relação à motivação dos alunos que dependem da aprovação em uma instituição pública para poderem prosseguir estudos em nível superior e, assim, entrarem em um mercado de trabalho mais qualificado e com melhor remuneração. Por esse motivo, eles estudam muito para conseguir alcançar seus objetivos, mesmo sabendo que suas chances são poucas se comparadas aos alunos das escolas particulares.

Como nos cenários das escolas particulares, as concepções de ensino e avaliação de LE dos professores dos cursos pré-vestibulares para afrodescendentes e alunos de baixa renda estão inseridas em uma abordagem tradicional, privilegiando o ensino de gramática e vocabulário de uma maneira fragmentada/ e descontextualizada e trabalhando a interpretação de texto somente em um nível superficial de reconstituição de informações pontuais lineares. Diferentemente dos alunos das escolas particulares, eles têm pouco conhecimento sistêmico da língua, e acabam estudando, equivocadamente, mais a gramática com itens isolados numa tentativa de minimizar suas deficiências. Essa prática, na verdade, não os ajuda a transpor essa barreira.

Neste estudo, notamos que há dois pólos distintos entre as escolas investigadas. De um lado, as escolas públicas que não preparam seus alunos para o ensino superior e, por esse motivo, o exame de inglês do vestibular da UFPR não exerce nenhuma influência no ensino da disciplina no ensino médio e, do outro lado, as escolas particulares, que concentram seus esforços para seus alunos prosseguirem os estudos no ensino superior. Neste cenário o efeito retroativo é percebido - ora positivo (estabelecem-se objetivos claros de ensino; o professor procura mais informação sobre o exame e, conseqüentemente, aperfeiçoa-se mais; os alunos tendem a estudar mais e prioriza-se a leitura), ora negativo (permanência do modelo de leitura ascendente; estreitamento de currículo, ou seja, ensino limitado ao desenvolvimento de uma única habilidade, no caso a leitura; o exame causa excesso de ansiedade tanto no professor que precisa aprovar seus alunos quanto nos alunos que precisam ser aprovados) . No meio do caminho, vemos os cursos pré-vestibulares para alunos de baixa renda e afrodescendentes tentando recuperar o tempo perdido nas escolas públicas e lutando para que seus alunos ingressem na UFPR e, através da educação superior, propiciando a possibilidade de ascensão social. Também constatamos efeito retroativo do exame da UFPR - ora positivo (prioriza-se a leitura, estabelecem-se objetivos claros de ensino, o exame motiva tanto os professores quanto os alunos que dependem da aprovação para sua ascensão social), ora negativo (manutenção de uma visão de leitura ascendente, ansiedade que o exame causa nos professores e alunos, pois o fracasso no exame o 
impede de ascender socialmente, limitação do currículo ao desenvolvimento de uma só habilidade, a leitura).

O discurso oficial dos diretores e professores das escolas EFA e LC é que o objetivo da escola pública é "formar o jovem para o trabalho", além de "formar o aluno para exercer a cidadania plena", discurso compartilhado pela coordenadora de língua inglesa da SEED e pelos documentos oficiais do MEC. Eles afirmam que a escola não tem a preocupação em preparar seus alunos para o vestibular da UFPR, pois os estudantes não expressam a intenção de fazer o exame por estarem muito distante da realidade vivida por eles. Discurso bastante questionável, uma vez que o discurso dos alunos é o oposto: não prestamos vestibular da UFPR porque a escola não nos prepara adequadamente. Os profissionais da escola pública não deveriam justificar o fracasso da escola pública culpando a falta de interesse dos alunos. É uma visão equivocada, pois uma vez que há o intuito de preparar seus alunos para a cidadania e inclusão social, seria coerente desenvolver programas para mudar essa imagem, ou seja, propiciar uma boa educação para que os alunos tenham capacidade de competir em grau de igualdade com os alunos da escola particular nos vestibulares de instituições públicas superiores.

A realidade do cenário da escola pública mostra que a proposta política pedagógica (PPP) e o planejamento da disciplina são impostos, muitas vezes, pela coordenação de cada escola que nada conhece da disciplina - como afirmou a coordenadora da SEED. Quando são elaborados pelos professores, que não têm embasamento teórico para entender e criticar os documentos oficiais, são de má qualidade (Apêndice H. 3 e H. 4; G. 4). Os professores constroem seus planejamentos a partir dos índices de conteúdos dos livros didáticos adotados, apesar de a escola LC ter copiado, aleatoriamente, alguns trechos dos PCNs também. Tais documentos não contribuem para o ensino acadêmico, nem para um ensino para o trabalho, muito menos para o desenvolvimento da cidadania. Apesar de os autores afirmarem que escrevem seu material para que seus alunos possam desenvolver a habilidade de interpretação de textos e prestar vestibular, o material pouco contribui para tal meta, uma vez que eles são calcados no ensino de gramática apenas. As aulas das professoras, bem como os materiais didáticos usados em sala de aula, também não contribuem para que os alunos atinjam um conhecimento para o trabalho, nem para a vida acadêmica e nem para a cidadania plena. A leitura é raramente abordada, e quando é, textos não autênticos e simplificados são utilizados e servem como pretexto para o ensino de gramática e vocabulário de maneira fragmentada. 
Através das falas dos alunos pudemos depreender que a desesperança toma conta deles. Eles sabem que não têm nível de conhecimento nem da língua inglesa, e nem das outras disciplinas, para competirem com seus colegas da escola particular na disputa por uma vaga em uma instituição pública superior. A resignação desses alunos mostra uma total sujeição e conformismo com a política de educação de exclusão que os governos têm imposto a eles ao longo dos últimos 42 anos. Os poucos que ingressam em cursos pré-vestibulares para baixa renda ou afro-descendentes, como o $\mathrm{KN}$ e o EA, sabem que têm uma batalha muito grande a enfrentar.

Esta pesquisa também aponta que o efeito retroativo de um exame pode estar relacionado com o prestígio que o exame tem na sociedade e como instrumento de seleção ajuda a contribuir e perpetuar a desigualdade social, ou seja, o efeito retroativo ocorre com mais intensidade e mais positivamente nas instituições das classes privilegiadas, ao passo que não ocorre nas escolas públicas. A desigualdade de classes alicerça-se na hegemonia do conhecimento, isto é, aqueles que a detêm garantem um lugar social privilegiado.

Um problema maior que envolve todos os sujeitos de todos os cenários deste estudo é que a prova de inglês do vestibular da UFPR é inconsistente, pois prioritariamente avalia a leitura aos moldes de uma visão ascendente. Porém, em alguns anos e em algumas questões, a visão de leitura parece estar pautada no modelo interativo. Essa oscilação pode provocar um efeito negativo, na medida em que o exame não oferece subsídios necessários sobre que modelo de leitura o exame é embasado e isso deixa os professores e elaboradores de material didático confusos em relação a que modelo seguir (os professores dos colégios particulares e cursos KN e EA e os elaboradores de materiais didáticos reclamaram dessa inconsistência - ver itens 5.3.2, 5.3.4, 5.4.2, 5.4.4, 5.5.2, 5.5.4, 5.6.2 e 5.6.4). Um outro problema é que os professores e elaboradores de material didático não conseguem ter uma visão aprofundada do exame e dos problemas que tal exame pode apresentar. Isso porque muitos professores possuem uma formação universitária deficitária o que os impossibilitam de fazer uma análise e critica adequado do exame.

Vindo ao encontro do que Alderson e Wall (1993, p. 116) afirmam 'que é certamente concebível que outras forças que existem na sociedade, educação e escolas podem impedir o efeito retroativo de acontecer, ou ainda afetar a natureza do efeito', neste estudo, percebemos que as circunstâncias políticashistóricas-sociais propiciam condições para que haja o efeito retroativo em um cenário - escola particular e curso pré-vestibular - e não em outro - escola pública. A hipótese de Alderson e Wall (op. cit.) de que testes que têm conse- 
qüências importantes causarão efeito retroativo é confirmada nos cenários escolas particulares e cursos pré-vestibulares, pois para esses dois cenários o vestibular da UFPR é de alta relevância. Porém, para os sujeitos dos cenários escolas públicas o exame não é de alta relevância uma vez que essa comunidade não tem como objetivo o ensino superior público - como eles não têm motivação para prestarem o vestibular da UFPR, o exame deixa de ser relevante para esse grupo. A conclusão de Scaramucci (1998, 1999b, 1999c, 2001/02, 2004a) de que mudanças introduzidas pelos exames não são suficientes para garantir inovações no ensino pode ser notada neste estudo, pois não há efeito retroativo nas escolas públicas e os efeitos retroativos sentidos nos cenários escolas particulares e cursos pré-vestibulares possuem algumas características em comum positivas (ajuda na definição de objetivos claros, os professores estão permanentemente buscando informações sobre o exame e como melhorar suas aulas, os alunos tendem a estudar mais) e negativas (estreitamento do currículo, restrição do ensino de leitura ao modelo ascendente) com intensidades diferentes (os alunos do Colégio DB, e dos cursos KN e EA estudam mais do que os do Colégio DP e escolas públicas; o professor e diretor do Colégio DB procuram muito mais informação e material didático adequado do que as professoras do Colégio DP e cursos KN e EA). Neste estudo percebemos ainda que os professores possuem formações e crenças bem distintas, o que dificulta que o efeito seja mais homogêneo. Além disso, os sujeitos do contexto da escola pública possuem um discurso "anti vestibular", "anti ensino superior" pautado em forças repressivas ("vocês não são capazes", "vocês não têm interesse", etc) e de sujeição à uma classe dominante, ao passo que o discurso das escolas particulares se apoia na afirmação da hegemonia de um grupo através da supremacia do conhecimento. Alderson e Hamp-Lyons (1996) afirmam que a intensidade e tipo de efeito retroativo irão variar de acordo com o status do teste (altamente relevante para escolas particulares e cursos pré-vestibulares e não relevante para escolas públicas); a quantidade de informação disponível sobre o teste (somente o Colégio DB tinha acesso às informações mais detalhadas); até que ponto o teste vai contra a prática de ensino corrente (a priorização da leitura nos cenários nos quais o exame é de alta relevância) e até que ponto os professores estão dispostos e capazes para inovar (percebemos que os professores dos cenários escolas particulares e cursos pré-vestibulares procuram informações sobre o exame e procuram novos materiais para ensinar, o que não ocorre com os professores das escolas públicas). A hipótese de Gimenez (1999, p. 36) que o efeito retroativo é dependente das crenças do professor a respeito das chances de aprovação de seus alunos se faz notar nos cenários 
escolas públicas, pois como as chances de aprovação são restritas, os professores não têm interesse em prepará-los para o exame, e nos cenários escolas particulares, há uma preocupação em prepararem seus alunos para o exame, pois sabem que as chances de aprovação são boas.

Outras hipóteses levantadas por Alderson e Wall (1992, 1993), Alderson e Hamp-Lyons (1996), Scaramucci (1998a e b, 1998/1999, 1999c, 2002a, 2004 a e b) e Gimenez (1999) também puderam ser confirmadas. Por exemplo, nas escolas particulares e cursos pré-vestibulares o exame de inglês da UFPR influencia o ensino (os conteúdos e habilidade que são ensinados/aprendidos ver apostilas nos anexos C, D, E e F). Notamos que o exame influencia o que (a leitura) os professores ensinam, mas a maneira como os professores ensinam ainda está pautada em concepções de língua, leitura, ensino e avaliação tradicionais (ver discussão das aulas dos professores nos itens 5.3.3, 5.4.3, 5.5.3, e 5.6.3). A prova de inglês da UFPR também influencia os cenários escolas particulares, o que os alunos aprendem (gramática, vocabulário e estratégias de leitura). Como o foco do exame mudou para a leitura, o vocabulário e estratégias de leitura foram incorporados ao ensino/aprendizagem e, por esse motivo, o exame determina o ritmo, seqüência, grau e profundidade com intensidades diferentes dependendo do histórico, conhecimento e necessidade do professor e de cada aluno. Por exemplo, o Colégio DB tem dois tipos de turmas: uma turma para alunos com pouco conhecimento da língua e uma outra para alunos que já possuem um bom conhecimento da língua. A partir dessa divisão, o material didático é proposto com níveis de ensino de gramática, vocabulário e interpretação de textos diferentes. A turma 'avançada', como eles a chamam, possuem aulas com grau e profundidade maior do que a turma regular (ver material didático no Anexo F). Diferenças em relação ao ritmo, seqüência, grau e profundidade do ensino entre o Colégio DP e os cursos KN e EA também puderam ser percebidas. Cada curso possui um ritmo de aula, uma seqüência de conteúdos a ser ensinado, um grau de dificuldade e profundidade desses conteúdos de acordo com as características de seus alunos, a formação e conhecimento de seus professores e informação que eles têm do exame de vestibular (ver discussão sobre as aulas desses professores nos itens 5.4.3, 5.5.3 e 5.6.3 e o material didático usados por eles nos anexos D, E e F).

De acordo com as dimensões do efeito retroativo descrito por Watanabe (2003, p. 20-2) podemos observar que em relação à especificidade, o exame de inglês do vestibular da UFPR produz efeitos gerais pois leva muitos professores, diretores e orientadores a se empenharem mais para conseguirem informações a respeito do exame e como eles podem preparar melhor seus alunos 
para tal avaliação. Um outro efeito geral está relacionado à motivação dos alunos: os que têm mais conhecimento da língua e, portanto, boas chances em passar, estudam mais, ao passo que os alunos que têm pouco ou nenhum conhecimento da língua não têm tanta motivação para estudar. O efeito mais específico está relacionado à priorização do ensino/aprendizagem da leitura, pois é o construto que o exame prioritariamente avalia.

Em relação à intensidade do efeito, podemos notar que o efeito é forte nas escolas particulares e cursos pré-vestibulares e fraco ou inexistente nas escolas públicas.

Em relação à extensão do efeito podemos dizer que nas escolas particulares ele tem uma duração extensa que começa no primeiro ano do ensino médio e vai até o terceiro ano (primeirão, segundão e terceirão como são conhecidos na cidade - ver itens 5.3.1, 5.3.2, 5.4.1 e 5.4.2). O efeito tem uma duração mais curta nos cursos pré-vestibulares que podem durar de 6 meses (cursos semiextensivos) a um ano (cursos extensivos).

$\mathrm{E}$, em relação à intencionalidade podemos verificar que o exame de inglês da UFPR provoca uma influência no ensino médio e cursos pré-vestibulares de algumas instituições (escolas particulares e cursos pré-vestibular KN e EA), mesmo não tendo a intenção de provocar tal impacto (como afirmaram os elaboradores do exame - ver item 4.2).

Neste capítulo, apresentei, analisei e discuti as percepções que os diretores, professores e alunos das escolas investigadas têm a respeito do exame de inglês do vestibular da UFPR, bem como as dos elaboradores de material didático que as escolas utilizam. Fiz uma triangulação entre os dados das percepções e das aulas assistidas.

No próximo capítulo, de apresentarei as conclusões, limitações e sugestões para futuras pesquisas.

\section{NOTA}

1 In parallel with identifying the problems in the society, the context where the test is used must also be described in detail. Thus, the questions that should be asked are:

* What does the educational system look like?

* What role does the test play in the system? 
